PERCEPCIÓN DE LAS ALTERNATIVAS DE REPARACIÓN EN RELACIÓN CON EL DAÑO PSICOSOCIAL Y EL IMPACTO DE LOS PROCESOS JUDICIALES EN DOS FAMILIAS VÍCTIMAS DE DESAPARICIÓN FORZADA

Mateus-Cubides, A., Mora-Pacheco, L., y Tapias, A.*

UNIVERSIDAD SANTO TOMÁS

MAESTRÍA EN PSICOLOGÍA JURÍDICA

BOGOTA, OCTUBRE - 2014

\footnotetext{
${ }^{*}$ Directora de tesis
} 
Percepción de reparación en familias de víctimas de desaparición forzada 2

Índice

Percepción de las alternativas de reparación en relación con el daño psicosocial y el impacto de los procesos judiciales en dos familias víctimas de desaparición forzada...............1

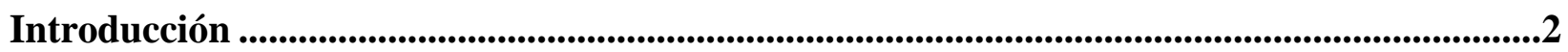

Fundamentación bibliográfica............................................................................................12

Víctima y victimización ......................................................................................................17

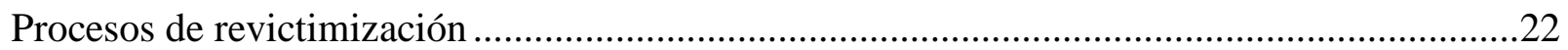

Daño moral, daño psicológico y daño psicosocial ...................................................................24

La desaparición forzada definición y cifras en Colombia..........................................................31

El proceso de desmovilización paramilitar en el contexto reciente, reparación integral y origen de la Ley 975 de Justicia y Paz................................................................................................

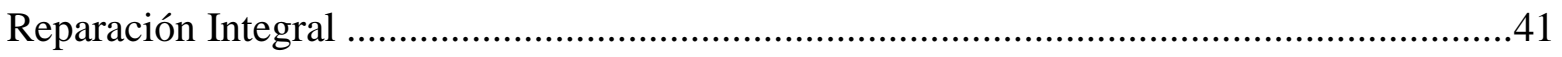

Desarrollo del concepto de percepción ....................................................................................4

Marco normativo en el contexto nacional e internacional sobre desaparición forzada................53

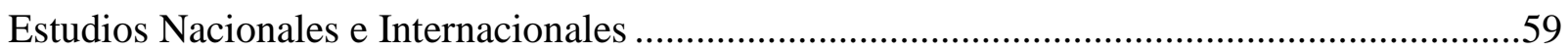

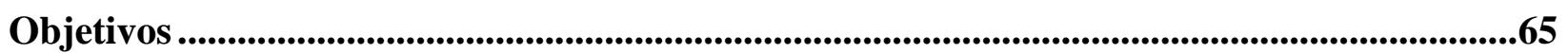

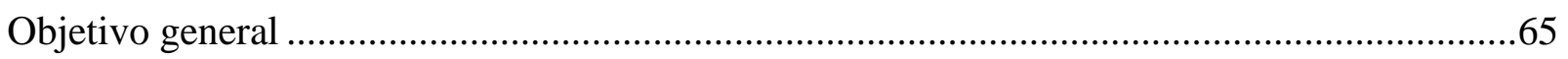

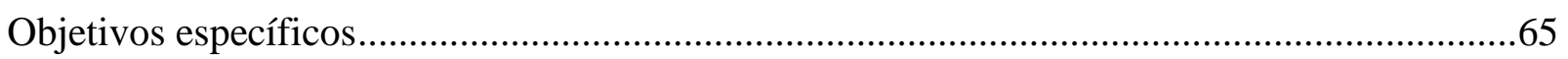

Conceptualización de categorías y variables .........................................................................................66

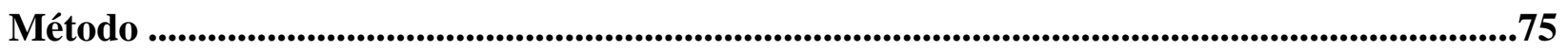

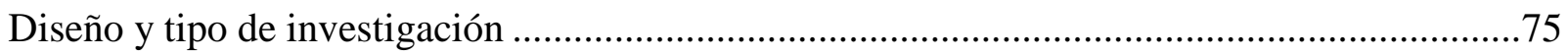

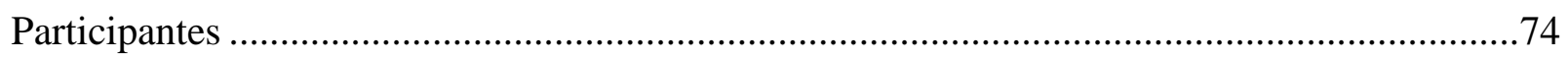

Técnicas de recolección de información e instrumentos.............................................................78

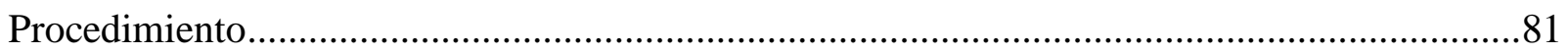


Percepción de reparación en familias de víctimas de desaparición forzada | 3

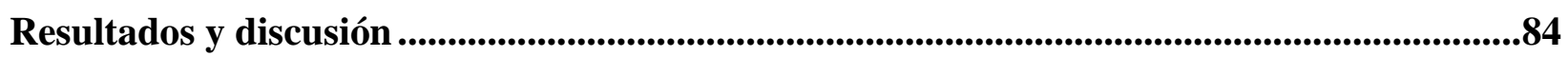

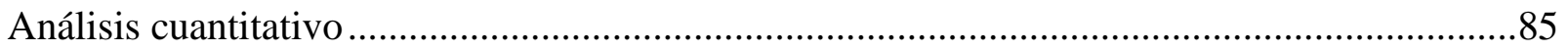

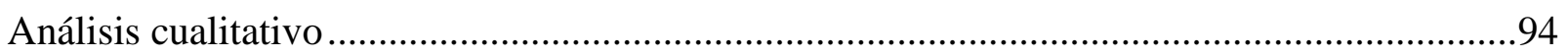

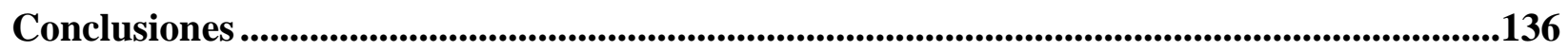

Referencias...............................................................................................................................................143

Apéndice A......................................................................................................................................................160

Apéndice B..........................................................................................................................................................161

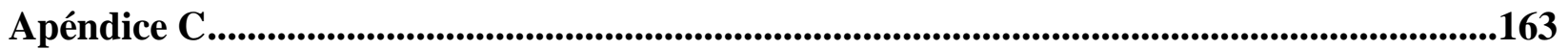

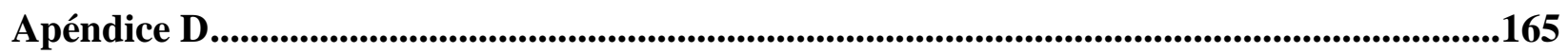

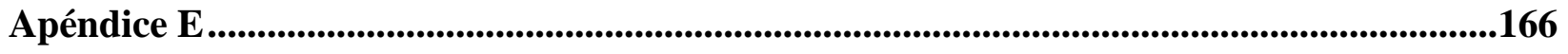

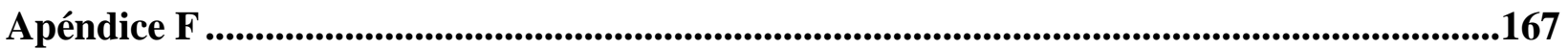

Apéndice G ...........................................................................................................................................................168

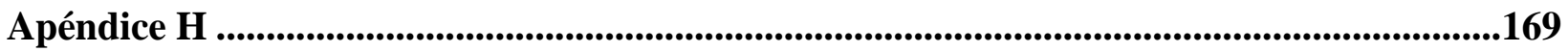




\section{Indice de Tablas}

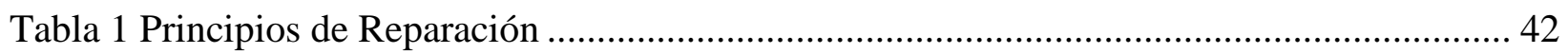

Tabla 2 Sentencias condenatorias contra Colombia por desaparición forzada-CIDH .............. 56

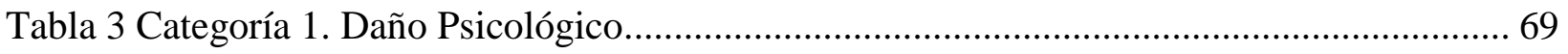

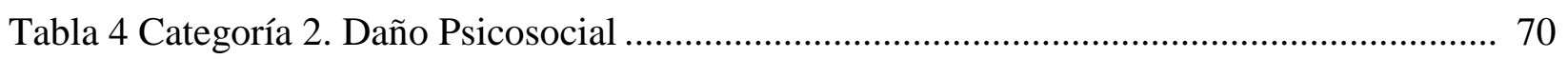

Tabla 5 Categoría 3. Percepción de Reparación .......................................................................... 71

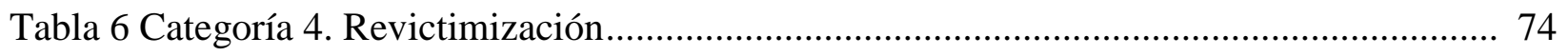

Tabla 7 Puntaciones por participantes del Cuestionario STAI ………………………............... 85

Tabla 8 Puntaciones en percentiles por participantes del IDER …………………................. 87

Tabla 9 Puntuaciones criterios diagnósticos trastorno paranoide de la personalidad IPDE ........ 89

Tabla 10 Puntuaciones criterios diagnósticos trastorno de la personalidad por evitación IPDE. 90 


\title{
Percepción de las alternativas de reparación en relación con el daño psicosocial y el impacto de los procesos judiciales en dos familias víctimas de desaparición forzada
}

\author{
Mateus-Cubides, A., Mora-Pacheco, L., y Tapias, A.*
}

\begin{abstract}
Resumen
La presente investigación exploró la percepción de las alternativas de reparación en seis familiares víctimas de desaparición forzada de personas en Barrancabermeja, relacionándola con el daño psicosocial y el impacto de los procesos judiciales. Los datos fueron recolectados mediante la técnica del grupo focal, la entrevista semiestructurada, instrumentos psicométricos y fuentes secundarias de información. Frente a las alternativas de reparación que no se han materializado, los familiares reportan sus expectativas, llevando alrededor de 10 años en el litigio, por lo tanto este trabajo enfatiza en la relación de sus expectativas y los impactos padecidos. Se evidencia que persisten el daño psicológico y psicosocial. A su vez la fatiga por la dilación del proceso judicial ha disminuido las expectativas frente a la eventual reparación que consideran no será eficaz por su inoportunidad, presentando como consecuencia desesperanza.
\end{abstract}

Palabras clave: Desaparición Forzada, Justica Transicional, Psicología Jurídica, Daño Psicológico, Daño Psicosocial, Victimología, Proceso Judicial.

\begin{abstract}
This investigation explored the perception of alternatives of repair by six family members of victims of enforced disappearances in Barrancabermeja in relation with psychosocial damage and the impact of the judicial process. Data was collected through focus group technique, semi-structured interviews, and review of secondary sources of information. As a result of the project, it was found in respect of alternatives of repair that the participants express that they have not materialized, as having to spend around 10 years in ligation and not having reestablished their violated rights, evidencing the persisting psychological and psychosocial damages. Finally, the fatigue arising from for the dilatation of legal process has diminished the expectations of obtaining justice and truth considering the process will not be efficient for its inappropriateness, presenting as consequence hopelessness as much for the judicial process as for the integral healing.
\end{abstract}

Keywords: Enforced Disappearance, Transitional Justice, Legal Psychology, Psychological Damage, Psychosocial Damage, Victimology, Judicial Process.

\footnotetext{
${ }^{*}$ Directora de tesis
} 
Percepción de reparación en familias de víctimas de desaparición forzada 2

\section{Introducción}

La realidad sociopolítica de Colombia exige de la comunidad científica y académica una visión crítica del entorno y una obligación por mitigar los efectos en los actores (víctimas, victimarios, sociedad) como consecuencia de los conflictos ya sean armados, por disputa de territorios, por la inequidad social, por deferencias políticas e ideológicas, por la injerencia de la delincuencia común o por la negligencia del Estado al no mantener su obligación de hacer valer los derechos fundamentales de sus habitantes, que por siglos se han desarrollado en nuestra región.

Las diferentes disciplinas básicas o aplicadas, incluyendo a la psicología jurídica, interesadas en asuntos sociales deben poner a disposición de las comunidades que las necesiten, las estrategias diagnósticas y de intervención más acertadas para que con principios éticos y humanistas permitan la movilización de la población víctima de alguna violación a sus derechos hacia mejores formas de vida que les contribuya a mitigar las secuelas de la tensión sociopolítica que continua perpetrándose, especialmente en las comunidades menos favorecidas.

En Colombia a través de su historia, se han configurado diferentes formas de estrategias armadas al margen de la ley. En este sentido, la Guía de atención en salud mental comunitaria específica y diferencial por crímenes de lesa humanidad para las víctimas del conflicto armado desde un marco de reparación menciona:

Los análisis estadísticos muestran claramente que, en las últimas décadas, las curvas de responsabilidad de la fuerza pública en violaciones a los derechos humanos y en crímenes de guerra solo descienden en la medida en que ascienden las de responsabilidad de los paramilitares. Esto ratifica la hipótesis de que el paramilitarismo fue diseñado como estrategia para saltarse los límites de la guerra, o sea para hacer lo que el DIH le prohíbe 
Percepción de reparación en familias de víctimas de desaparición forzada 3

hacer a los agentes directos del Estado. Y aunque no se probara que fue diseñado para esos propósitos, funciona, de hecho, en esa lógica. Pero si la parte que reivindica el carácter institucional dentro del conflicto, goza de un mecanismo permanente y poderoso para saltarse los límites, o sea, para ignorar o burlar el DIH, es cada vez más difícil enjuiciar a la parte anti-institucional por traspasar algunos de esos límites, CINEP (2008) pág. 30, (pág.32).

Por lo anterior, se observa que en los últimos años con mucha fuerza se conformó una estrategia de exterminio paramilitar centrada en el control de la vida cotidiana, social, política y económica, que ha conducido a una crisis humanitaria y de Derechos Humanos. La desaparición forzada de hombres y mujeres ha sido un crimen de lesa humanidad recurrente en todas las regiones del país desde hace varios años. El carácter sistemático, masivo y permanente que evidencian los centenares de casos de desaparición forzada perpetrados durante décadas, así como múltiples familias victimizadas, muestra que tal crimen de lesa humanidad viene siendo implementado como una estrategia de guerra adelantada bajo una política estatal de agresión. En tal sentido, en un informe del Observatorio de Paz Integral OPI, se reporta que desde el año 2005, pese a la desmovilización de las autodefensas que se dio en la región del Magdalena Medio, han surgido nuevas estructuras paramilitares cuya finalidad es mantener el control sociopolítico, militar y económico de la región, dando continuidad a su accionar delictivo que se ve reflejado en los homicidios selectivos, las amenazas individuales y colectivas, las desapariciones forzadas, el cobro de extorsiones bajo el supuesto de garantizar seguridad; entre otras acciones, que vulneran múltiples derechos, entre ellos el derecho a la vida (OPI, 2011).

En la actualidad, el llamado Proceso de Justicia y Paz (Ley 975/05) de cierta forma ha contribuido a poner de presente la existencia y práctica de esta conducta atroz, que ha sido 
Percepción de reparación en familias de víctimas de desaparición forzada | 4

develada por la ubicación de fosas comunes lograda por la confesión de algunos victimarios, ha estremecido a su vez el diario vivir de los colombianos y ha pretendido que se busque y se justifique una extensión de la responsabilidad que le concierne al Estado por estas desapariciones, respondiendo así a sus objetivos de lograr verdad, justicia y reparación integral a las víctimas del conflicto armado colombiano. Por lo tanto, es de resaltar la definición de víctima que recoge la presente ley en su artículo 5:

Artículo 5: Definición de Víctima. Para los efectos de la presente ley se entiende por víctima la persona que individual o colectivamente haya sufrido daños directos tales como lesiones transitorias o permanentes que ocasionen algún tipo de discapacidad física, psíquica y/o sensorial (visual y/o auditiva), sufrimiento emocional, pérdida financiera o menoscabo de sus derechos fundamentales. Los daños deberán ser consecuencia de acciones que hayan transgredido la legislación penal, realizadas por grupos armados organizados al margen de la ley.

A su vez, en el contexto nacional, a partir de la creación de la Corte Constitucional en la Carta de 1991 se da inicio a una línea jurisprudencial tendiente a ampliar la participación y fines de la víctimas en el proceso penal, planteando que las victimas concurren al proceso con el propósito no solo del resarcimiento económico sino, principalmente en la búsqueda de verdad y justicia como fines constitucionales del proceso penal en el Estado Social de Derecho (Camargo, 2012).

La victima en la actualidad asume un nuevo rol en el proceso penal, el cual consiste en que esta no solamente acude como testigo, sino que se constituye como parte civil y puede dar impulso a la investigación a fin de obtener, además de una reparación de los perjuicios materiales, la garantía de los derechos a la verdad y la justicia. Lo anterior, basado en una 
Percepción de reparación en familias de víctimas de desaparición forzada $\mid 5$

legislación internacional o bloque de constitucionalidad que promueve la protección de las víctimas y a su vez sirve de herramienta de restablecimiento de derechos en armonía con el Derecho Internacional Humanitario y las diferentes convenciones adoptadas desde un enfoque diferencial (Alzate, Sierra, Méndez y Trujillo, 2006).

La reparación integral de las victimas incluyendo el daño psicológico consecuente, se tiene presente en el marco legislativo colombiano y en la agenda de la formulación de planes, programas o proyectos con enfoque psicosocial, encaminados a garantizar medidas de asistencia y atención a las víctimas, no obstante, merece un análisis más profundo para describir la situación actual de la justicia restaurativa y su incidencia en la reparación del daño psicológico de las víctimas, pues se han puesto a disposición medidas jurídicas para garantizar los principios generales de la justicia restaurativa, sin embargo falta claridad en la implementación de medidas psicosociales viables que se puedan articular a los servicios que actualmente prestan las instituciones estatales, saturando la buena voluntad e iniciativas de las ONG presentes en nuestro país o restándole continuidad a los programas que brindan atención terapéutica o psicosocial en los municipios y ciudades, debido a la rotación, reducción o carencia de personal capacitado para brindar la atención oportuna y especializada requerida por las víctimas (Procuraduría General de la Nación, 2009).

Por tal motivo, es vital para la psicología jurídica tomar partida y entrar a delimitar los alcances de cada posición agresor-víctima en la parte penal y brindar pautas en los aspectos psicosociales inherentes a su ciencia para que de esta forma pueda dar una mirada técnica que aclare a los operadores judiciales y al Estado una acertada toma de decisiones frente a las políticas de reparación y su ruta de aplicación. 
Percepción de reparación en familias de víctimas de desaparición forzada | 6

A su vez, en torno a las víctimas de delitos de lesa humanidad se genera un debate de interés público, por ello es significativo retomar la victimología, que según Beristain (1997) es básicamente el estudio de la víctima, de la persona que padece un sufrimiento físico, psicológico y social, a consecuencia de la violencia o de una conducta antisocial, que puede estar tipificada ante la ley como un daño al bien jurídico, o no; de la valoración de las secuelas y las formas terapéuticas de reparación o reintegración social.

De esta forma y desde el campo de la victimología, surge la presente investigación que se realizó desde la Maestría de Psicología Jurídica en la Facultad de Posgrados en Psicología Jurídica de la Universidad Santo Tomás, en conjunto con seis familiares víctimas del delito de desaparición forzada de personas que hacen parte del proceso de Justicia y Paz en la ciudad de Barrancabermeja, Santander. El proyecto se enmarcó en la línea de investigación de la Maestría en Psicología Jurídica, que busca indagar e investigar la afectación de las víctimas, la viabilidad y efectividad de las estrategias psicojurídicas en relación con la reparación integral de las mismas dentro del conflicto armado colombiano.

Para contextualizar al lector y ofrecerle una radiografía del fenómeno de desaparición forzada en el Magdalena Medio, región en donde acaecieron los hechos victimizantes objeto de esta investigación, se hace necesario hacer alusión a la información del banco de datos del Centro de Investigación y Educación Popular- CINEP (2004), para el periodo comprendido entre los años 2000 a 2003, cuando la ciudad de Barrancabermeja fue afectada específicamente y formalmente por el paramilitarismo, en donde se consolida una estrategia de control social que ha logrado romper el tejido social, amedrentando a la comunidad para que se abstenga de exigir el respeto por sus derechos (Centro de Investigación y Educación Popular CINEP, 2004). 
Percepción de reparación en familias de víctimas de desaparición forzada $\mid 7$

Es necesario precisar que entre febrero de 2000 y diciembre de 2003, miembros de grupos paramilitares que ejercen control social, político y militar en la ciudad de Barrancabermeja, Santander asesinaron a más de 1.000 personas y desparecieron forzadamente a cerca de 300 ciudadanos donde los cuerpos fueron arrojados al río o enterrados en múltiples fosas comunes y/o desmembrando sus extremidades, en el casco urbano de la ciudad y en los municipios de Sabana de Torres, Lebrija, Puerto Wilches y Simacota (Santander.), Yondó y Puerto Berrio (Antioquia.), San Pablo y Cantagallo (Bolívar), (Centro de Investigación y Educación Popular CINEP, 2004).

Recientemente, para el año 2014 el Sistema de Información Red de Desaparecidos y Cadáveres- SIRDEC del Instituto Nacional de Medicina Legal y Ciencias Forenses ha publicado que en Barrancabermeja, Santander hay un total de 550 desaparecidos frente a 32 personas muertas.

En la actualidad, luego de 6 años de cumplido el proceso de Justicia y Paz, la Fiscalía General de la Nación a través de su Unidad Nacional de Justicia y Paz, a 31 de Julio de 2011 ha documentado 36.011 casos de desaparición forzada. Delitos en hechos en confesión de desaparición forzada 2.546. Con respecto a las fosas exhumadas, se han hallado 3.378, en las cuales se han encontrado 4.185 cadáveres, siendo los cuerpos con identificación indiciaria (espera resultados de ADN) 877; cuerpos plenamente identificados con ADN o carta dental 1.594, cuerpos entregados a familiares 1.491 y finalmente cuerpos identificados pendientes de entrega 103 (Unidad Nacional de Fiscalías para la Justicia y la Paz, 2011).

Para la zona del departamento de Santander, la Fiscalía General de la Nación seccional Bucaramanga, manifestó que para el año 2010 había exhumado 62 cadáveres y entregado 29, los restantes 33 estaban en proceso de identificación. A pesar de esto, frente al impacto psicosocial 
Percepción de reparación en familias de víctimas de desaparición forzada $\mid 8$

que todos estos procesos le generan a las víctimas, no se hace alusión dentro de las estadísticas, por ello es necesario dimensionar el daño psicosocial que causa a los esfuerzos de las víctimas y organizaciones, el retardo o frustración de obtener verdad, justicia y reparación integral, teniendo en cuenta que a la fecha aún no ha habido el primer pronunciamiento definitivo para el Magdalena Medio (Unidad Nacional de Fiscalías para la Justicia y la Paz, 2011).

Más allá de las cifras y al margen de la responsabilidad del Estado colombiano por la desaparición forzada de personas mediante sus propios y directos agentes, surgen muchos cuestionamientos y cabe indagar: ¿cuándo la justicia ó el ente encargado del Estado no puede devolver al familiar el cuerpo del desaparecido, qué ocurre con las víctimas si no es posible que la triada de verdad, justicia y reparación se cumpla?, ¿cuál sería el aporte desde lo psicojurídico en el componente de reparación integral cuando la triada no se cumple o cuando no hay un destino final del cuerpo puesto que muchos de ellos fueron arrojados al río?, si bien es cierto, mucho se ha documentado en materia de reparación frente a los delitos de lesa humanidad en Colombia, gracias a las disertaciones e investigaciones adelantadas por expertos académicos, legisladores, asesores estatales, funcionarios públicos, políticos, entre otros actores de la sociedad, ¿qué se sabe de la reparación desde la óptica de las víctimas? y particularmente desde las víctimas que llevan largos periodos en contacto con el sistema judicial sin lograr resolver su proceso jurídico, por ello esta investigación que se centra en dos casos concretos, permite relacionar los perjuicios padecidos y analizar las expectativas de reparación con las particularidades del delito de desaparición forzada. En este sentido, la pregunta e hilo conductor que sirvió como guía del presente estudio es: ¿Cuál es la percepción frente a las alternativas de reparación y su relación con el daño psicosocial y el impacto de los procesos judiciales en dos familias víctimas de desaparición forzada de personas? 
Percepción de reparación en familias de víctimas de desaparición forzada $\mid 9$

Teniendo en cuenta que son pocos los estudios científicos realizados hasta el momento en Colombia sobre la exploración del fenómeno de la desaparición forzada de personas, las afectaciones emocionales en sus familiares, y la percepción o significados que tienen los mismos frente a las alternativas de reparación, esta investigación propicia que las víctimas participen activamente de su proceso de reparación integral lo que mitigaría las afectaciones ocasionadas.

Los hallazgos de la investigación podrían tomarse en cuenta a la hora de ofertar las reparaciones y concretar su cumplimiento atendiendo a las expectativas de las víctimas, haciendo eco a la aplicación del enfoque diferencial y contrarrestando las políticas en materia de reparación administrativa, que pretenden reparar a todas las victimas por igual.

Adicionalmente, como retribución a las victimas participantes, se evaluaron los daños psicológicos y psicosociales, a fin de ser aportados a sus procesos judiciales y se brindó un acompañamiento psicojurídico para orientarlas y empoderarlas a la hora de reclamar sus derechos en el marco de la Ley 1448 de 2011.

A su vez, desde el ejercicio académico se contribuye a garantizar la memoria histórica local y a mantener una rememoración de estas victimizaciones que aún no reciben una verdad jurídica ni una reparación integral.

A continuación se exponen brevemente los hechos que dieron lugar a la desaparición de Jeisson Duarte de la Ossa y Benjamín Duarte, según lo relatado por los familiares participantes y luego se presentan las bases teóricas y metodológicas de esta investigación, los objetivos, los impactos encontrados a nivel individual, familiar, su discusión y conclusiones.

\section{Caso Jeisson Duarte de la Ossa:}

El joven Jeisson Duarte de la Ossa, que al momento de su desaparición tenía 17 años de edad, era estudiante de soldadura en el Sena. El 24 de mayo de 2004, día de los hechos, Jeisson 
se encontraba departiendo con su madre y unos amigos en su vivienda ubicada en el barrio El Progreso del municipio de Yondó (Antioquia). Alrededor de las 2:00 de la madrugada él y dos amigos más, se dirigieron a la licorería de nombre 'La Terraza', ubicada a escasos metros de su vivienda, con el objetivo de comprar más aguardiente. Al parecer, en el lugar los jóvenes intentaron hurtar una botella de licor por lo que el dueño del establecimiento identificado como Jaime Alberto Pilonieta retuvo de manera ilegal y con amenaza de revólver al joven Jeisson Duarte de la Ossa.

Horas después el joven fue entregado por parte del señor Pilonieta a miembros de las Autodefensas Unidas de Colombia que operaban en la zona, desde ese día su madre, familiares y amigos no lo han vuelto a ver.

En las recientes versiones libres se ha podido esclarecer que el joven fue retenido durante una semana en una bodega ubicada en La Laguna del Miedo de allí huyó para luego ser recapturado y posteriormente asesinado, sin embargo su cuerpo no ha sido hallado.

\section{Caso Benjamín Duarte:}

"Yo me encontraba trabajando, cuando llego a la casa en horas de la tarde, me cuentan que mi padre Benjamín Duarte desapareció cuando se dirigía hacia el trabajo, que tenía con una empresa contratista, cuando llegó un amigo de él y le dijo que lo llevara en su moto a un lugar, me cuentan que mi sobrino fue el último de la familia que lo vio con vida, y él le dijo que antes de entregar el trabajo iba a llevar a un amigo, y esa fue la última persona que lo vio con vida. En ese mismo instante salí a buscarlo, pero nadie daba razón de él, yo estaba lleno de angustia y desesperación, después fue que nos enteramos, porque le hacen una llamada a mi tía diciéndole que no lo buscáramos más que el (Benjamín) ya estaba muerto y nunca lo íbamos a encontrar" 
"Para finales del año de 2000 que es la separación de mis padres, mi papá (Benjamín) es amenazado de muerte, él se muda para donde mi abuela en una finca del municipio de Yondó (Antioquia), allí siguen las amenazas, y Benjamín hace caso omiso, puesto que mi papá con la separación quedo muy mal, nada le importaba.

El día que desapareció mi papá, él estaba haciendo entrega del trabajo que tenía (limpiar el monte a orilla de la carretera y el río) con una empresa contratista, cuando llegó un amigo de él y le dijo que lo llevara en su moto a un lugar, Benjamín le dijo que si lo esperaba, antes de que se fueran los dos, Benjamín se encuentra con un sobrino y le dijo que antes de entregar el trabajo iba a llevar a un amigo.

El sobrino es quien le hace saber a toda la familia de Benjamín sobre ese último momento que lo vio con vida. Desde ese día que salió a las 7 a.m. no volvieron verlo, siendo las 5 p.m. empezaron la búsqueda con la Defensa Civil, la policía, al día siguiente llamaron a una tía y le dijeron que no lo buscara más, que él ya estaba muerto, que a él nunca lo iban a encontrar. Empezaron los rumores por el pueblo sobre la muerte de mi padre, fue así como se entera mi mamá, ya sin poder ocultárselo más mi hermano decidió decirle la verdad.”, manifiesta J. C. 


\section{Percepción de reparación en familias de víctimas de desaparición forzada 12}

\section{Fundamentación bibliográfica}

En la actualidad los profesionales en psicología han sido incluidos dentro de muchos campos de trabajo, especialmente en la administración de justicia. El Consejo General de Colegios Oficiales de Psicólogos en España (COP) desde los 80`s ha hecho eco de ello y en él hallamos un área bajo el rotulo de Psicología Jurídica, asimismo lo podemos encontrar en Colombia oficialmente desde hace varios años en el Colegio Colombiano de Psicólogos, como lo manifiesta Duque (2011) en su conferencia realizada en la Universidad Iberoamericana. Algunas de las aportaciones de la psicología ya han iniciado su camino: psicólogos de juzgados de familia, de menores, forenses y de penitenciaria. No obstante el papel del psicólogo en el ámbito jurídico aún está en auge y requiere de mayor interés por parte de las entidades e incluso de otros profesionales como los abogados, lo que permitiría una toma de decisiones más acertada.

Para entender en que consiste la psicología jurídica, Tapias (2002) citado por Duque (2011), la define como el estudio, asesoramiento e intervención sobre el comportamiento humano que se desarrolla en un ambiente regulado por normas (p. 22); tiene como escenarios de aplicación las instituciones judiciales, centros penitenciarios, juzgados, entes donde se investiga el delito y en general ambientes y realidades que a menudo no son imaginables por la gran mayoría de personas que componen la sociedad, pero que lo son para sus usuarios-victimas, victimarios y funcionarios, hasta el punto de modificar profundamente sus vidas.

La psicología se relaciona con el derecho de diversas formas, comparten su objeto de estudio, (la conducta del hombre como ser bio psicosocial pero además un ser ético y jurídico que en cualquier cultura o medio social necesariamente se halla bajo la influencia de las normas ya sean estas de carácter legal o consuetudinario), no obstante, lo hacen desde perspectivas u objetivos diferentes. Por su parte, la psicología se encarga de comprender la conducta, explicarla, 
predecirla, prevenir aquellas que afectan a otro (s), controlarla, no así el derecho, pues se limita a describir y prohibir aquellos comportamientos que van en contra de las leyes de una sociedad y a aplicar correctivos que en su gran mayoría distan del conocimiento de las leyes de la naturaleza humana y por ende resultan inadecuados e ineficaces frente a las necesidades del contexto.

En la actualidad, de acuerdo con Gutiérrez de Piñeres (2010) cuando cita el concepto del grupo de profesores de los posgrados en Psicología Jurídica de la Universidad Santo Tomas (2009), como:

[...] la psicología jurídica es un área especializada, básica y aplicada de la psicología científica, que investiga e interviene sobre el comportamiento humano que alcanza implicaciones jurídicas. Esta área propende por la defensa de los Derechos Humanos, la salud mental y el impacto de éstas en la sociedad, con el fin de alcanzar y humanizar [...] (p. 223).

Siendo este un concepto idóneo para ilustrar qué es la psicología jurídica.

Por tanto, la psicología jurídica cumple sin duda un papel preponderante dentro de cualquier contexto social, político, y aporta soluciones a problemas de la realidad social que el derecho por sí solo no lograría desentrañar a partir de la aplicación de la ley positiva. Vale la pena tener en cuenta tres formas de relación entre estas dos disciplinas planteadas por Muñoz Sabaté (1980) acerca de las cuales existe un creciente interés por parte de los nuevos profesionales:

En la primera, se pretende explicar la ciencia jurídica, centrándose en la fundamentación del derecho. Uno de los retos actuales desde esta posición es lograr que el psicólogo participe en el proceso de elaboración de leyes, estudie los valores, representaciones sociales, procesos de la justicia y estudie entre otros temas el delito. En la segunda, el 
psicólogo cumple el rol de asesor, desde sus conocimientos orienta a jueces y tribunales, en general a profesionales del derecho para la consecución de sus objetivos, facilita información importante sobre la interpretación de las pruebas aportadas, y en el proceso de decisión de un veredicto. También sirve como asesor a la acusación y a la defensa, apoya al fiscal en su actuación con las víctimas y testigos, ayuda en la presentación e interpretación de pruebas, interviene con los testigos o víctimas, explica e interpreta todos los términos Psicológicos que utiliza la norma, etc. En su tercera posición el psicólogo se desempeña como auxiliar de la justicia el cual es el caso concreto del campo de actuación forense en la que el profesional evalúa, explica y aplica todas las ramas y saberes para responder a las preguntas de la justicia y coopera en todo momento con la administración de justicia actuando en el tribunal y mejorando el ejercicio del derecho (p.125).

Es de vital importancia tener en cuenta que en este último tipo de relación prima el factor individual sobre el colectivo, tienen lugar aquí los peritajes cuya realización implica valorar y explicar la personalidad y todos aquellos aspectos que requiera el ente judicial para tomar decisiones con respecto a los sujetos.

Conocer los ámbitos de trabajo de la psicología jurídica donde el profesional se desempeña como teórico, como asesor o como auxiliar de la justicia revela sus conquistas a pesar de que aún algunos de estos campos se hallan parcialmente restringidos. Los temas de estudio principales se hallan contenidos en los siguientes campos: psicología criminológica, psicología aplicada a la investigación criminal, psicología penitenciaria, psicología policial o militar, resolución de conflictos, psicología de la víctima, psicología forense, y dentro de esta un amplio campo de aplicación, la psicología del testimonio, (Hernández, 2011). 
Para la Evaluación Psicológica Forense, según Rodríguez y Ávila (1999), la declaración del psicólogo jurista se inscribe funcional y significativamente en y para el sistema en el que opera. Estos autores parten de la propuesta sistemática de Blau, (1984) quien propone las siguientes etapas:

1. Iniciación del caso (que en nuestro proyecto sería la recepción o remisión por parte del abogado del equipo)

2. Preparación del expediente (revisión de todos los datos aportados en la primera entrevista

3. Recogida de datos (corresponde a la documentación que se realiza en forma conjunta con el abogado)

4. Evaluación de necesidades (según lo sugerido en casos de delitos de lesa humanidad, ampliar en las dimensiones familiar, social)

5. Selección de estrategias (según los requerimientos y las características del caso)

6. Informe pericial (emisión del concepto técnico final) (p.29-33).

En el sistema penal mixto se consideraba un medio de prueba dentro de un proceso judicial, el sistema acusatorio solo será admisible como evidencia si el perito declara oralmente en el juicio. En el sistema mixto podía ser objeto de complementación: completar, aclarar, ampliar; en el acusatorio las cuestiones que genere son absueltas en el juicio oral. El dictamen puede llegar a ser objetado en caso de considerarse error, violencia o dolo. Por último, el informe debe ser: claro, preciso, fundamentado, objetivo, informativo, descriptivo de la evidencia, bien escrito, organizado.

A pesar de que estos aspectos deben ser considerados por el psicólogo experto, cuando se interviene en casos de delitos de lesa humanidad se recomienda hacer especial énfasis en los 
siguientes aspectos (Protocolo del Informe Pericial utilizado actualmente por los peritos adscritos al Instituto Nacional de Medicina Legal y Ciencias Forenses en Colombia):

Ampliar la perspectiva de la evaluación psicológica forense y mostrar la dimensión del sufrimiento como el componente esencial en el cambio experimentado tras el evento violento. Mostrar el daño producido en la esfera relacionada con el disfrute de la vida, su significado, su deterioro.

Dimensionar el significado del dolor aprehendido en términos de intencionalidades externas. Contemplar la dimensión emocional expresada por la víctima en la sensación de vulnerabilidad, abandono, culpabilidad, impotencia, negación, miedo y falta de control de la situación.

El ejercicio psicoforense va más allá de los aspectos clínicos característicos, el daño trasciende lo individual, para expresarse por medio del dolor familiar y grupal. Aborda la dimensión social.

No se reduce a la descripción, el psicólogo construye una forma de presentar, registrar o mostrar lo expresado por medio del lenguaje.

La labor del psicólogo jurídico a través de las herramientas y protocolos que emplea, permite abordar uno de los principales dramas de la violencia política en Colombia, como lo es la desaparición forzada de personas y sus secuelas, que día a día y de manera sistemática, afecta a un considerable número de personas, familias y comunidades entre opositores políticos, sindicalistas, defensores de derechos humanos y la población vulnerable, víctima de todo tipo de abusos subsecuentes al delito en mención. 


\section{Víctima y victimización}

Son varias las definiciones encontradas sobre en concepto de víctima, algunas de aproximación jurídica y otras desde una postura académica, por lo tanto se hace un breve recorrido para contextualizar su definición. Según la ley 975 de 2005 o ley de Justicia y Paz, las víctimas tienen derecho a la verdad, la justicia, la reparación y a ser reconocidas como víctimas para acceder al conocimiento de las causas, circunstancias y responsables que rodearon el hecho delictivo. La definición que recoge la ley 975 de 2005 define en su artículo 5:

Artículo $5^{\circ}$. Definición de víctima. Para los efectos de la presente ley se entiende por víctima la persona que individual o colectivamente haya sufrido daños directos tales como lesiones transitorias o permanentes que ocasionen algún tipo de discapacidad física, psíquica y/o sensorial (visual y/o auditiva), sufrimiento emocional, pérdida financiera o menoscabo de sus derechos fundamentales. Los daños deberán ser consecuencia de acciones que hayan transgredido la legislación penal, realizadas por grupos armados organizados al margen de la ley.

Tomando en cuenta la anterior definición de víctima según la ley 975 de 2005, se puede observar que se desprende de la resolución 40/34 del 29 de noviembre de 1985 emitida por la Asamblea General de las Naciones Unidas (1985) en su noventa y seisava Plenaria en la que refiere que se ha de entender por victimas las personas que individual o colectivamente hayan sufrido daños, inclusive lesiones físicas, mentales, sufrimiento emocional, perdida financiera, o menoscabo sustancial de sus derechos fundamentales como consecuencia de acciones $u$ omisiones que violen la legislación vigente en los estados miembros, incluida la que proscribe el abuso de poder. En la expresión víctima, se incluye además a los familiares y personas a su cargo 
que tengan relación con la víctima y las personas que hayan sufrido daños al intervenir para asistir a la víctima en peligro.

De la misma manera la Ley 1448 de 2011, la nueva ley para las víctimas en su Artículo 3. Refiere que:

VÍCTIMAS. Se consideran víctimas, para los efectos de esta ley, aquellas personas que individual o colectivamente hayan sufrido un daño por hechos ocurridos a partir del 1o de enero de 1985, como consecuencia de infracciones al Derecho Internacional Humanitario o de violaciones graves y manifiestas a las normas internacionales de Derechos Humanos, ocurridas con ocasión del conflicto armado interno.

También son víctimas el cónyuge, compañero o compañera permanente, parejas del mismo sexo y familiar en primer grado de consanguinidad, primero civil de la víctima directa, cuando a esta se le hubiere dado muerte o estuviere desaparecida. A falta de estas, lo serán los que se encuentren en el segundo grado de consanguinidad ascendente.

De la misma forma, se consideran víctimas las personas que hayan sufrido un daño al intervenir para asistir a la víctima en peligro o para prevenir la victimización.

La condición de víctima se adquiere con independencia de que se individualice, aprehenda, procese o condene al autor de la conducta punible y de la relación familiar que pueda existir entre el autor y la víctima.

PARÁGRAFO 3o. Para los efectos de la definición contenida en el presente artículo, no serán considerados como víctimas quienes hayan sufrido un daño en sus derechos como consecuencia de actos de delincuencia común.

PARÁGRAFO 5o. La definición de víctima contemplada en el presente artículo, en ningún caso podrá interpretarse o presumir reconocimiento alguno de carácter político 
sobre los grupos terroristas y/o armados ilegales, que hayan ocasionado el daño al que se refiere como hecho victimizante la presente ley, en el marco del Derecho Internacional Humanitario y de los Derechos Humanos, de manera particular de lo establecido por el artículo tercero (3o) común a los Convenios de Ginebra de 1949. El ejercicio de las competencias y funciones que le corresponden en virtud de la Constitución, la ley y los reglamentos a las Fuerzas Armadas de combatir otros actores criminales, no se afectará en absoluto por las disposiciones contenidas en la presente ley.

Específicamente hablando de víctima de desaparición forzada de personas, la Asamblea General de las Naciones Unidas (2006), en la resolución A/RES/61/177 de la Convención internacional para la protección de todas las personas contra las desapariciones forzadas en su artículo 24, refiere:

1. A los efectos de la presente Convención, se entenderá por "víctima" la persona desaparecida y toda persona física que haya sufrido un perjuicio directo como consecuencia de una desaparición forzada.

2. Cada víctima tiene el derecho de conocer la verdad sobre las circunstancias de la desaparición forzada, la evolución y resultados de la investigación y la suerte de la persona desaparecida. Cada Estado Parte tomará las medidas adecuadas a este respecto.

3. Cada Estado Parte adoptará todas las medidas apropiadas para la búsqueda, localización y liberación de las personas desaparecidas y, en caso de fallecimiento, para la búsqueda, el respeto y la restitución de sus restos. (p. 11)

De manera amplia se reconoce el hecho de que la víctima no es solamente quien padece el daño o agresión de primera mano, sino que asimismo tanto su familia y comunidad se ven seriamente afectadas por los traumas de la guerra, generando la necesidad de comprender el 
fenómeno de la violencia sociopolítica desde una perspectiva psicosocial. Además los efectos sobre las poblaciones afectadas no solamente generan traumas a nivel físico sino que también hay un impacto en su salud mental (Martín-Baró, 1990).

Por lo anterior, el concepto de víctima queda estrictamente ligado al campo de victimología el cual a su vez se encuentra relacionado con la criminología. La Victimología como disciplina surge a partir de las investigaciones de Mendelsohn y Von Henting a mediados del siglo XX, quienes como consecuencia de la victimización masiva durante la segunda guerra mundial empiezan a plantear la necesidad de ahondar en estudios no solo en quien venía ejecutando el daño sino en quien lo recibe (Ferreiro, 2005).

En palabras de Beristain (2006), la victimología es entendida como la ciencia y el arte pluridisciplinar que en relación con la praxis del derecho penal, la criminología, la sociología, la filosofía y la teología, investiga la victimación primaria, secundaria y terciaria, así como sus factores etiológicos, sus controles, sus consecuencias y sus respuestas superadoras de los conflictos y la delincuencia. Presta atención al análisis biopsicosocial de las diversas clases de víctimas, no solo las directas e inmediatas.

El concepto de víctima es tan antiguo, proviene del latín y está ligado a quien es destinado al sacrificio, pero fue solamente hasta los años 40’s que se empezó su estudio sistemático con Benjamín Mendelsohn, considerado el padre de la victimología.

Diversos autores han desarrollado las tipologías victimológicas para estudiar el rol de la víctima y entender sus características más significativas.

Mendelsohn, fundamenta su clasificación en la correlación de culpabilidad entre víctima y el infractor. Sostiene que hay una relación inversa entre la culpabilidad del agresor y la del ofendido, a mayor culpabilidad del uno, menor la culpabilidad del otro (Márquez, 2011). Sin 
Percepción de reparación en familias de víctimas de desaparición forzada | 21

embargo, para el delito de desaparición forzada nunca se podrá establecer que la víctima tenga culpabilidad en el delito, por lo cual estaría cargada esta responsabilidad enteramente al trasgresor.

Por otro lado, Hans Von Henting (1979), intenta una explicación desde los factores de vulnerabilidad de las víctimas clasificación en la que se aparta de criterios legales para proponer cinco categorías de "clases generales" y seis de "tipos psicológicos". No pretende hacer una clasificación de todas las víctimas, sino de categorizar a las más frecuentemente victimizables (Manzanera, 2005). En este sentido, en Colombia se observa especial vulnerabilidad a convertirse en víctimas de desaparición forzada en defensores de derechos humanos, periodistas, grupo de personas que tienen militancia política opositora, población radicada en lugares cercanos a enfrentamientos entre la fuerza pública y grupos armados al margen de la ley (zonas rojas).

Luis Jiménez de Asúa (1961) elabora una tipología partiendo del plano y la óptica en los que se mueve el delincuente. Ubica a las víctimas en dos categorías sustánciales:

Victimas indiferentes: al victimario le es indiferente la víctima contra la cual ejerce violencia. Ejemplo típico es el arrebato. Al victimario no le interesa ni el nombre, ni la condición de la víctima, lo único que interesa es apoderarse de los valores que lleva.

Víctimas determinadas. El victimario dirige sus actos contra una persona determinada. Ejemplo, en el crimen pasional, al hombre que mata a la mujer que le ha sido infiel, no le da igual matarla a ella que a otra mujer; tiene que ser determinada, concreta, esa mujer. Víctimas resistentes. Es aquélla víctima que ante un ataque con un cuchillo o revolver, se defiende de tal manera que pueda llegar a matar en legítima defensa.

Víctimas coadyuvantes: son aquellas que "colaboran" a su propia victimización. 
Asúa pone como ejemplo de víctimas coadyuvantes a las víctimas de tiranicidio, los homicidios justicieros, los homicidios pasionales, los duelos, la riña, el suicidio, los delitos sexuales, las muertes y las lesiones en accidentes causados por otros y aquellos contra la propiedad, en especial la estafa (Manzanera, 2005).

Como critica a esta tipología se establece que no es una clasificación sino que más bien se trata de una sistematización de tipo genérico. Sostiene que las víctimas anónimas o indefinidas no tienen mayor relevancia para la victimología (Márquez, 2011).

Por su parte, Elías Neuman agrega una clasificación en la que agrupa a las víctimas en tres categorías, individuales, familiares, colectivas y víctimas de la sociedad o del sistema social (Manzanera, 2005). El delito de la desaparición forzada tiene impacto en todos los niveles, empezando por las víctimas directas, el duelo subsecuente en sus familias y el impacto en las relaciones sociales.

Al revisar la literatura se encuentra que con el transcurso del tiempo han surgido diferentes estudios y clasificaciones como los mencionados anteriormente, pero no se trata aquí de hacer un recorrido exhaustivo, por ello solo se mencionan los estudios pioneros a manera de recuento.

\section{Procesos de revictimización}

Colombia, de manera similar a otros países latinoamericanos, ha tenido que soportar situaciones de violencia sistemática perpetradas por agentes del estado y grupos al margen de la ley, que desafortunadamente se desencadenan en revictimización e impunidad.

Para el caso de Guatemala, país en situación de postconflicto, se ha documentado el impacto de la impunidad en testigos de masacres. Cabrera y Martin B (2000) describen los mecanismos de impunidad más frecuentes tales como obstaculización intencional de las 
Percepción de reparación en familias de víctimas de desaparición forzada | 23

investigaciones por las autoridades, alteración o pérdida de pruebas; dificultades operativas en la realización de exhumaciones, intimidaciones y amenazas a los testigos porque representan un testimonio innegable y agentes de la justicia dando paso a que se filtre la corrupción, la falta de colaboración de jueces y fiscales y retrasos injustificados en el trámite de procesos. Todos los anteriores dejan como secuela miedo, tristeza y frustración a las víctimas.

La impunidad como mecanismo de revictimización, se puede explicar históricamente por la falta de tipificación del delito de desaparición forzada en Colombia hasta antes del año 2000, lo que hacía que las familias denunciaran el hecho por secuestro simple u optaran por no denunciar. Lo anterior, aunado al no castigo a los responsables, permitió que se generalizara el problema, puesto que ya no sólo se desaparecían a líderes sociales, militantes de izquierda y opositores políticos, sino también a campesinos y pobladores, con los argumentos de ser supuestamente simpatizantes de la guerrilla, como lo sucedido en las regiones de Urabá, Cauca y Magdalena Medio (Gómez y Muñoz, 2012.).

Varios autores han hablado de los niveles de victimización haciendo especial énfasis en la victimización secundaria o revictimización, entendida como la inadecuada atención que reciben las victimas a lo largo de un proceso judicial (Gutiérrez de Piñeres, 2009).

La revictimización propicia dilación y falta de información de la situación procesal que nada tiene que ver con el secreto sumario. La incertidumbre de un proceso penal inconcluso y la reacción de la parte denunciada pueden agravar la situación emocional de la víctima al someterla a nuevas agresiones, incomprensión o injurias (Echeburúa, Corral, Amor, 2002).

En casos de desapariciones forzadas, masacres y genocidios, el Estado Colombiano ha tenido una reiterada falta de respuesta a las familias que incansablemente buscan a sus seres queridos. Continúan la falta de garantías en la búsqueda, recuperación e identificación de 
Percepción de reparación en familias de víctimas de desaparición forzada $\mid 24$

personas desaparecidas a pesar de existir una legislación en la materia como la Ley 589 de 2000.

Adicionalmente hay carencia de equipos y personal técnico especializado o no existen planes de búsqueda efectivos, que en el mejor de los casos, de encontrarse los cuerpos, muchas veces no se procede a su identificación dando como resultado la generación de NN. Aunado a lo anterior, la identificación y entrega de los restos encontrados muchas veces se hace por la presión constante de los familiares y en condiciones inapropiadas, lo que supone un desgaste emocional, físico y económico, generando nuevas experiencias de revictimización y falta de garantías y protección para las víctimas sobrevivientes (Pérez-Sales y Navarro, 2007).

\section{Daño moral, daño psicológico y daño psicosocial}

Según Esbec, (1994) citado por Sicard (2011), se habla de lesión psíquica como: "Una Consecuencia Traumática de un acontecimiento que desborda la tolerancia del sujeto, derivando en elementos patológicos remisibles o no". Sicard (2011) refiere que esta definición ilustra sobre cómo el impacto que genera un evento adverso, como lo puede ser el conflicto armado, puede generar desde un perjuicio en lo espiritual, en lo moral, en la dignidad y en la paz (daño moral) hasta un daño en la salud (daño psíquico) que deviene en perturbaciones, trastornos y anomalías equivalentes a una lesión personal, que incluso puede incidir en la capacidad laboral por las consecuentes afecciones a nivel de la salud mental.

De otra parte, Esbec (1994) citado en Sicard (2011), diferencia el daño moral del daño psíquico tomando la jurisprudencia europea en la cual la lesión psíquica está contenida al interior del daño moral. De esta manera define el daño moral como la "Percepción del sujeto de un perjuicio, más que de un sufrimiento que impacte la salud mental".

En España, autores como Arce y Fariña (2007), han establecido procedimientos de valoración, tasación y ponderación del Daño Psíquico y moral, a partir de los postulados de 
Percepción de reparación en familias de víctimas de desaparición forzada | 25

Blanchard y Hickling (2004) y la American Psychiatric Association (2004). En ellos se establece la importancia de realizar una experticia forense que determine la magnitud del daño en estricta relación con el evento adverso y para ello establecen mecanismos cualitativos y cuantitativos de valoración del daño moral. Dichos métodos son de antigua tradición en las indemnizaciones por seguros y accidentes de tráfico y destaca que las lesiones psíquicas se pueden medir según el grado de deficiencia, déficit, minusvalía e invalidez, y por consecuencia se puede determinar el monto de lo indemnizable y compensable en relación a la capacidad laboral del individuo.

Sin embargo, en el panorama colombiano cabe aclarar la diferencia entre "daño psíquico", "perturbación psíquica" y "daño moral”. El daño psíquico surge de un acontecimiento que afecta la estructura vital y generalmente acarrea trastornos y efectos patógenos en la organización psíquica, esto de acuerdo con Tkaczuk (2001) citado en la Guía para la Realización de Pericias Psiquiátricas o Psicológicas sobre Daño Psíquico con fines de indemnización, conciliación o reparación del INML y CF (2011).

Es decir, el daño psíquico se refiere al deterioro de funciones psíquicas, como ocurrencia de un evento externo sobre el cual puede reclamarse jurídicamente una responsabilidad, lo que implica valorar el estado actual de la víctima en comparación con el estado anterior (INML y CF, 2011).

A diferencia de lo anterior, el daño moral subjetivo, se presenta como respuesta a la agresión sufrida con los hechos y se asimila al duelo normal; donde muchas veces no hay afectación psíquica pero puede haber un detrimento en otros aspectos extrapatrimoniales, en este sentido la estimación del daño moral no es una pericia psiquiátrica o psicológica forense, sino que compete al juez (INML y CF, 2011). 
Percepción de reparación en familias de víctimas de desaparición forzada | 26

Otra distinción es la que existe entre las experticias de daño psíquico y perturbación psíquica. Las dos tienen en común la identificación del impacto que sobre la salud psíquica de una persona tiene el hecho investigado y las recomendaciones terapéuticas que derivan de esta condición. Pero mientras en la pericia sobre "perturbación psíquica" el fin primordial es orientar a la autoridad respecto de la configuración de un tipo penal para imponer una sanción, en la relativa al "daño psíquico con fines de indemnización, conciliación o reparación” el propósito último es definir las condiciones de tratamiento que deben ser posteriormente tasadas por la autoridad y poder restablecer la salud de la persona afectada (INML y CF, 2011).

En el ordenamiento el código penal colombiano, artículo 111 de ley 599 de 2000 indica sobre las lesiones personales: "El que cause a otro daño en el cuerpo o en la salud, incurrirá en las sanciones establecidas en los artículos siguientes”. Define el Instituto Nacional de Medicina Legal y Ciencias Forenses que las Lesiones personales son: "...cualquier daño del cuerpo o de la salud orgánica o mental de un individuo llamado lesionado, causado externa o internamente por mecanismos físicos, químicos, biológicos o psicológicos, utilizados por un agresor, sin que se produzca la muerte del ofendido...”(p.05).

El bien jurídico protegido en este tipo penal es la integridad personal, (integridad corporal, la integridad de la salud y la vida de relación o integridad social). A nuestros fines las perturbaciones y lesiones derivadas de un suceso traumático como lo puede ser el desplazamiento, el secuestro, la presencia de violaciones de los derechos humanos, impacta de manera determinante en la psique de las víctimas y por ende, dichas lesiones se convierten en evidencias de un delito y dicho impacto deberá ser ponderado para establecer la magnitud de la lesión psíquica (Artículo 115 CP ley 599 de 2000. Perturbación psíquica. Si el daño consistiere en perturbación psíquica transitoria, la pena será de prisión de dos (2) a siete (7) años y multa de 
veintiséis (26) a cuarenta (40) salarios mínimos legales mensuales vigentes. Si fuere permanente, la pena será de tres (3) a nueve (9) años de prisión y multa de veintisiete (27) a cincuenta (50) salarios mínimos legales mensuales vigentes). De allí sería evidente que la "Reparación" puede darse a partir de la evidencia psicológica y científica del daño Psíquico y una vez clarificado el daño psíquico, la Justicia, la reparación y la compensación permitirán hacer real el principio de la justicia restaurativa (Sicard, 2011).

Sin embargo, tal es la magnitud de las afectaciones sufridas por las victimas inmersas en el conflicto armado que vale la pena ampliar la mirada del daño netamente psíquico a una valoración del daño psicosocial, debido a que intervenciones terapéuticas centradas en lo individual, podrían tener un efecto negativo en las personas en vez de poner el énfasis en la reconstrucción del tejido social que se ha fragmentado.

En tal sentido, Martín-Baró (1990) habla de trauma psicosocial, entendido como la herida o afectación, relacionada con la vivencia de la persona y sus características de personalidad, que a su vez están condicionadas por su contexto social y su grado de participación en el conflicto.

Debido a que la violencia entre las comunidades y los individuos continua, se requieren condiciones favorables para la reparación integral, luego de los hechos violentos ocurridos y que permitan un mejor afrontamiento como acción preventiva frente a la repetición de los mismos, (Rebolledo y Rondón, 2010)

Bien lo describen Rebolledo y Rondón (2010) al afirmar que la percepción del daño es subjetiva, es decir, va más allá de identificar factores de similitud basados en criterios diagnósticos, e implica entender los significados subjetivos que las víctimas atribuyen a lo perdido durante la guerra. 
Percepción de reparación en familias de víctimas de desaparición forzada | 28

En este sentido es posible valorar el daño psicosocial desde dos ópticas, lo individual y lo familiar, entendiendo que evaluar el daño individual requiere ampliar su análisis desde dos conceptos fundamentales: la noción de sufrimiento (que en Colombia se entiende como daño moral) y la de proyecto de vida.

La noción de sufrimiento reconoce diferentes reacciones que tienen los seres humanos frente a las situaciones adversas en las distintas esferas no sólo individuales sino también familiares y las afectaciones en los vínculos que dejan duelos sin elaborar. Se conecta entonces con el concepto de proyecto de vida, y con las afectaciones de esos hechos y del daño adicional ocasionado por la impunidad y la desatención, que cobra un valor retroactivo en la capacidad de los individuos de reconstruir sus vidas, (Rebolledo y Rondón, 2010, p.42).

Así mismo, valorar el daño grupal o familiar implica entender que:

El individuo está involucrado en estructuras sociales más amplias; ha heredado un histórico colectivo de las formas de violencia que ha afectado su comunidad y además de heredarla, la ha significado en un discurso social propio. En el caso de las intervenciones individuales, por ejemplo, aun cuando estas pueden mitigar el impacto en un sujeto, éste regresa a un contexto social en donde se requiere integrar y acompasar los procesos de recuperación colectivos (Sironi, 2008 citado en Rebolledo y Rondón, 2010, p. 43).

Por otro lado, en el ordenamiento jurídico colombiano ha variado sustancialmente la concepción de los diferentes tipos de daños, y en particular la noción y las implicaciones del daño colectivo:

[...] la falta de regulación sobre el daño colectivo, no hay claridad sobre su contenido específico, quién debe probarlo y cómo, y si se debe discutir audiencia por audiencia o en un 
Percepción de reparación en familias de víctimas de desaparición forzada | 29

espacio diferente. Subsanar estas dificultades debería hacerse en armonía con las disposiciones de la Ley 1448 de 2011 en materia de reparación colectiva y con las propuestas en este sentido efectuadas por la CNRR (Observatorio Internacional sobre el proceso de DDR y la Ley de Justicia y Paz, 2011, p. 12)

Otro aspecto a tener en cuenta es que delitos como la desaparición forzada de personas, están acompañados de otros, como el asesinato y la tortura en donde se generan dolores físicos o psíquicos con el fin de obtener información, castigar, intimidar o coaccionar sea cual sea la razón. En el caso de las personas desaparecidas, se emplea la tortura como método correctivo, preventivo a través de un castigo ejemplar para atemorizar e intimidar a la comunidad (Quintero, 2010).

Sin embargo a pesar de que situaciones como la desaparición forzada de un ser querido, no deja evidencias de maltrato físico si ocasiona un efecto devastador en el núcleo familiar generando a mediano y largo plazo secuelas somáticas de daños físicos, emocionales, psicológicos y psicosociales, (Quintero, 2010, p.13).

Para los casos de desaparición forzada, donde se asumen daños a nivel individual, familiar y comunitario, se esperan daños tales como, tristeza, duelo alterado, abuso de sustancias psicoactivas, deterioro de las relaciones familiares y sociales, perdidas económicas, estigmatización, frustración tras la impunidad de los hechos, terror extremo (angustia) manifestado en el temor a hablar y denunciar, llegar al lugar de las exhumaciones o temor a que les pueda ocurrir lo mismo que a sus seres queridos entre otros daños (Gómez, 2009).

Tras la muerte de un familiar asesinado por un actor de la violencia las personas atraviesan por una fase de impacto e incredulidad, hay una negación la pérdida para protegerse de la realidad, mientras pasa el tiempo hasta que poco a poco se va asimilando lo ocurrido. A medida 
que pasan los días, los familiares de las personas asesinadas van tomando conciencia de la pérdida y empiezan a experimentar dolorosos sentimientos, tales como la tristeza, la ansiedad, el desasosiego, reacciones normales ante la pérdida abrupta de un ser querido (Aguilera, 2006).

Según el Programa de Atención Psicosocial y Salud Integral a Víctimas, en el marco de la ley 1448 de 2011, algunas particularidades según el hecho victimizante, en la desaparición forzada son:

Desestructuración de redes sociales y comunitarias, distorsión de tiempo, duelos congelados, desestructuración del tejido social y quebrantamiento de liderazgos y procesos organizativos. Los daños causados por violaciones de los derechos humanos generalmente trascienden la individualidad del sujeto o sujetos directamente afectados, alcanzando por lo general a afectar al grupo familiar, a la comunidad u organización social e incluso a toda la sociedad. (Pág.34)

La Comisión Colombiana de Juristas (2009) amplía: En los casos de desaparición forzada, los familiares de la víctima pueden sufrir durante años por la incertidumbre sobre la suerte que pudo correr su ser querido.

Generalmente, afrontan duelos complicados o patológicos ante la falta de certeza de que la víctima ya no se encuentra con vida. Los familiares, además pueden llegar a incurrir en gastos descomunales adelantando acciones de búsqueda de su familiar por cuenta propia, abandonar sus trabajos o sus roles tradicionales para concentrarse en la localización de la víctima. Las familias suelen vivir un luto prolongado y tormentoso que no da lugar a vivir las fechas conmemorativas o de celebración, como de costumbre. Muchas veces ya no tiene cabida la alegría debido a que ello puede generarles profundos sentimientos de culpa (Aguilera, 2006). 
Riviera (2009) manifiesta que este delito, puede provocar incluso la desintegración familiar, por razones de protección de quienes se encuentran amenazados de muerte.

Arévalo, Serrato, Rodríguez (2011), afirman que se generan duelos congelados en el tiempo, la desarticulación o reagrupación de los miembros de la familia en torno a la búsqueda de la persona desaparecida, trastocando los roles y las formas de tramitar de manera individual y colectiva la pérdida de un ser querido. Los impactos psicosociales generados por el delito de la desaparición forzada terminan agravándose en virtud de contextos marcados por la impunidad, la imposición de la versión oficial sobre lo sucedido y el silencio forzado de las víctimas" (Pág.45)

\section{La desaparición forzada definición y cifras en Colombia.}

El contexto sociohistórico y político colombiano se caracteriza por ser uno con los más altos índices de violación a los derechos humanos en el mundo. Según un informe de la Comisión Colombiana de Juristas (CCJ), en la década de los ochentas del siglo XX, Colombia alcanzó altos niveles de violencia tal como lo reflejan las siguientes cifras estadísticas:

Diez personas muertas cada día por agentes estatales y grupos paramilitares (en un 70\% de los casos en promedio) y por grupos guerrilleros (en un 30\% de los casos, en promedio), sin que la justicia actuara eficazmente en un $99 \%$ de los casos. Esos niveles de violencia se duplicaron en los primeros años del siglo XXI: veinte personas muertas cada día por agentes estatales y grupos paramilitares (en un $85 \%$ de los casos, en promedio) y por grupos guerrilleros (en un15\% de los casos en promedio), con un índice de impunidad igualmente alto. Los niveles de pobreza en aquellos años fueron iguales o superiores al $50 \%$ (CCJ, 2004).

Así mismo, el Centro de Investigación y Educación Popular (CINEP) refiere que desde años anteriores a la década de los ochenta, estos niveles de violencia se han venido elevando. En 
Percepción de reparación en familias de víctimas de desaparición forzada | 32

los 70’s se presentaron un gran número de denuncias relacionadas con torturas infligidas a los prisioneros políticos por parte de los miembros de la fuerza pública y de organismos de seguridad del Estado, pero en los 80's, en el tiempo de los primeros "diálogos de paz" entre gobierno e insurgencia, las torturas comenzaron a transformarse en desapariciones forzadas y en ejecuciones extrajudiciales (CINEP, 2008)

Por su parte, Christian Salazar, representante en Colombia de la Alta Comisionada de las Naciones Unidas para los Derechos Humanos OACNUDH refiere:

Los últimos estimados por parte de la unidad de Justicia y paz, piensan en forma realista, que en Colombia hay por lo menos 50.000 personas desaparecidas, lo cual implica que por lo menos hay unas 200.000 personas afectadas por esta violación de los Derechos Humanos. Este altísimo número de víctimas de Colombia, mayor que el de los desaparecidos en Argentina, exige el diseño y la ejecución de una política pública en contra de la desaparición forzada (Naciones Unidas de Colombia, s.f).

De acuerdo a la Asociación de Familiares de Detenidos Desaparecidos ASFADDES (citado en CINEP, 2004), se observa que:

Entre el año 1984 y el año 2003, ha habido un total de 6875 desapariciones forzadas. Tal crimen, indica ASFADDES, ha sido implementado en Colombia de manera creciente, desde el año 1996, así: año 1996: 176 casos; 1997: 83 hechos; 1998: 323; 1999: 443; 2000: 749; 2001: 1604; 2002: 1358; 2003: 1188 casos de desaparición forzada.

Son varios los grupos que han cometido delitos de desaparición forzada en Colombia, de acuerdo con Beristain y Gómez (2007):

Algunas zonas del país han experimentado ciclos de violencia desde hace más de cinco décadas, mientras que otras presentan modalidades de violencia más reciente. Los actores 
del conflicto colombiano son: la guerrilla, en la que se destacan las Fuerzas Armadas Revolucionarias de Colombia (FARC) y el Ejército de Liberación Nacional (ELN), los paramilitares, principalmente las Autodefensas Unidas de Colombia (AUC), y las fuerzas de seguridad oficiales (Policía Nacional, Fuerzas Armadas de Colombia y Departamento Administrativo de Seguridad) (p. 4).

El primer caso de desaparecimiento forzado en Colombia documentado y formalmente denunciado, es el de Omaira Montoya Henao de 30 años de edad, bacterióloga de la Universidad de Antioquia, militante del Ejército de Liberación Nacional ELN, quien al momento de su captura estaba embarazada y padecía de una afección cardiaca. Fue detenida y desaparecida junto con su compañero Mauricio Trujillo, por unidades del F2 (Inteligencia de la Policía) en Barranquilla, departamento de Atlántico, el 9 de septiembre de 1977. Tras ser torturado, Mauricio Trujillo fue judicializado y condenado a siete años de cárcel. De Omaira y el hijo que esperaba, por el contrario, nunca se volvió a saber su paradero. Estos hechos ocurrieron durante el gobierno del presidente Alfonso López Michelsen (1974-1978), mientras se desarrollaba un paro cívico nacional contra las medidas antipopulares del gobierno (Corporación Jurídica Libertad, 2009).

Cabe recordar que el delito de desaparición forzada no es exclusivo del territorio Colombiano y a nivel latinoamericano casos lamentables como el de Argentina y Chile, países en donde se ha reconocido la injerencia de regímenes dictatoriales han dejado miles de víctimas. Asimismo tal como lo ilustra el banco de datos del CINEP, después de la segunda guerra mundial (1939 - 1945), se llevó a cabo el Tribunal de Nuremberg, en Alemania, para juzgar los crímenes de guerra cometidos por los nazis. Allí se definieron los crímenes de lesa humanidad, y aunque no se incluyó el crimen de desaparición forzada como tal, en dicho tribunal se 
reconstruyó el famoso decreto Noche y Niebla de Hitler (1941), donde se ordenaba que las personas detenidas por atentar contra la seguridad alemana fueran trasladadas en secreto a ese país y desaparecidas al amparo de "la noche y la niebla" (CINEP, 2004)

Ubicando la problemática de la violencia sociopolítica en un contexto nacional reciente, en el marco del drama de la desaparición forzada y retomando cifras oficiales de la Unidad Nacional de Fiscalías para la Justicia y la Paz a 29 de febrero de 2012, existen aproximadamente 3172 delitos en hechos de confesión de desaparición forzada.

Con respecto a las fosas exhumadas, se han hallado 3.649, en las cuales se han encontrado 4.503 cadáveres, siendo los cuerpos con identificación indiciaria (espera resultados de ADN) 866; cuerpos plenamente identificados con ADN o carta dental 1.651, cuerpos entregados a familiares 1.669 y finalmente cuerpos identificados pendientes de entrega 144 , según la Unidad Nacional de Fiscalías para la Justicia y la Paz (2012).

Para la zona del departamento de Santander, la Fiscalía General de la Nación Seccional Bucaramanga, manifestó que a 31 de enero de 2012 había encontrado 112 cadáveres y entregado 42. A pesar de esto, frente al impacto psicosocial que todos estos procesos le generan a las víctimas, no se hace tangible dentro de las estadísticas, por ello es necesario dimensionar el daño psicosocial que causa a los esfuerzos de las víctimas y organizaciones el retardo o frustración de obtener verdad, justicia y más aún reparación integral teniendo en cuenta que a la fecha aún no ha habido el primer pronunciamiento definitivo para el Magdalena Medio.

Específicamente Barrancabermeja, puerto petrolero ubicado a orillas del magdalena, en una región fuertemente azotada por el paramilitarismo en los últimos años, ha sido el escenario de una estrategia represiva de desestabilización social como lo es la desaparición forzada y 
homicidios sistemáticos de cientos de personas, todo lo anterior bajo la preocupante impunidad al no obtener plena justicia, verdad y reparación de las víctimas directas e indirectas.

Según el testimonio de un defensor de derechos humanos de esa región, miembros de grupos paramilitares ejercen control social hacia la población civil, entre febrero de 2000 y diciembre de 2003, en el casco urbano de Barrancabermeja y en los municipios de Sabana de Torres, Lebrija, Puerto Wilches y Simacota (Santander), Yondó y Puerto Berrío (Antioquia), San Pablo y Cantagallo (Bolívar), se llevaron a cabo más de 1.000 asesinatos y desaparecieron forzadamente unas 300 personas, sobre la mayoría de desaparecidos no se ha vuelto a saber nada y de quienes se han encontrado los cadáveres o restos de ellos, se han hecho evidentes signos de tortura (CINEP, 2004).

Definir el delito de la desaparición forzada parece fácil, pero debido a la multicausalidad de este fenómeno y de su comisión con el acompañamiento de otros delitos como la tortura, ejecuciones extrajudiciales, detenciones arbitrarias, amenazas previas, violencia sexual, entre otros, se hace necesario delimitar el fenómeno a través de definiciones oficiales.

Claramente la desaparición forzada atenta contra el derecho a la libertad personal y diversos instrumentos normativos nacionales e internacionales se han dado a la tarea de especificar en qué consiste y una definición adoptada de desaparición forzada, es:

que se arreste, detenga o traslade contra su voluntad a las personas, o que éstas resulten privadas de su libertad de alguna otra forma por agentes gubernamentales de cualquier sector o nivel, por grupos organizados o por particulares que actúan en nombre del gobierno o con su apoyo directo o indirecto, su autorización o su asentimiento, y que luego se niegan a revelar la suerte o el paradero de esas personas o a reconocer que están privadas de la libertad, sustrayéndolas así a la protección de la ley (Declaración sobre la 
Percepción de reparación en familias de víctimas de desaparición forzada | 36

protección de todas las personas contra las desapariciones forzadas de las Naciones Unidas, 1992)

Así mismo, según el Estatuto de la Corte Penal Internacional en Roma, la desaparición forzada es uno de los once crímenes de lesa humanidad, que se aplican generalizada o sistemáticamente a la población civil (Naciones Unidas, 1998).

En el artículo II de la Convención Interamericana sobre Desaparición Forzada de Personas se describe este delito de la siguiente manera:

Se considera desaparición forzada la privación de la libertad a una o más personas, cualquiera que fuere su forma, cometida por agentes del Estado o por personas o grupos de personas que actúen con la autorización, el apoyo o la aquiescencia del Estado, seguida de la falta de información o de la negativa a reconocer dicha privación de libertad o de informar sobre el paradero de la persona, con lo cual se impide el ejercicio de los recursos legales y de las garantías procesales pertinentes (Convención Interamericana sobre Desaparición Forzada de Personas, 1994).

La corte constitucional de Colombia, por su parte, ha considerado que la definición del artículo $2^{\circ}$ de la Convención Interamericana sobre Desaparición Forzada de Personas establece un mínimo que debe ser protegido por los Estados partes, sin perjuicio de que estos adopten definiciones más amplias dentro de sus ordenamientos internos.

La legislación Colombiana tipificó el delito de la desaparición forzada luego de seis proyectos desde 1988; en el año 2000, mediante la citada ley 589 del 6 de julio del 2000 y luego mediante la promulgación del código penal (ley 599 de 24 de julio del 2000), más adelante, fue como la ley 589 incorporó al código penal el tipo de desaparición forzada en los siguientes términos: 
Percepción de reparación en familias de víctimas de desaparición forzada | 37

Artículo 268 : Desaparición Forzada: El particular que perteneciendo a un grupo armado al margen de la ley somete a otra persona a privación de su libertad cualquiera que sea la forma, seguida de su ocultamiento y de la negativa a reconocer dicha privación o de dar información sobre su paradero, sustrayéndola del amparo de la ley, incurrirá en prisión de 25 a 40 años.

A la misma pena, quedará sometido el servidor público o el particular que actué bajo la determinación o la aquiescencia de aquel, y realice la conducta descrita en el inciso anterior.

El código penal de la ley 599 adoptado, algunos días después de la ley 589 de 2000, incorporó un tipo penal similar en cuanto a la descripción de la conducta punible, pero modificó el régimen punitivo del ilícito, antes previsto de 25 a 40 años y ahora de 26,6 y 45 años (320 a 540 meses). En efecto, el tipo penal de desaparición forzada descrita en el artículo 165 del código penal suscribe:

El particular que perteneciendo a un grupo armado al margen de la ley someta a otra persona a privación de su libertad cualquiera que sea la forma, seguida de su ocultamiento y de la negativa a reconocer dicha privación o de dar información sobre su paradero, sustrayéndola del amparo de la ley, incurrirá en prisión de 320 a 540 meses(...) El tipo penal adoptado tanto por la ley 589 y el código penal resultaba problemático y no estaba en conformidad con la definición del crimen de desaparición forzada de personas y otros instrumentos o estándares internacionales. La corte constitucional de Colombia al examinar la constitucionalidad del artículo 165 del código penal, declaro mediante la sentencia de constitucionalidad $\mathrm{n}^{\circ}$ 100/11 inexequible el texto "perteneciendo a un grupo armado al margen de la ley”. Así que el crimen de desaparición forzada quedó tipificado de la siguiente forma: 
El particular que someta a otra persona a privación de su libertad cualquiera que sea la forma, seguida de su ocultamiento y de la negativa a reconocer dicha privación o de dar información sobre su paradero, sustrayéndola del amparo de la ley, incurrirá en prisión [...]. A la misma pena quedará sometido, el servidor público, o el particular que actúe bajo la determinación o la aquiescencia de aquél, y realice la conducta descrita en el inciso anterior” Ley 599/00, Art. 165.

¿Quién es víctima de desaparición forzada de personas?

Como lo manifiesta Albaladejo (2009), la normativa internacional consagra una definición de víctima que incluye a la persona desaparecida y a toda persona física que haya sufrido un perjuicio directo como consecuencia de una desaparición forzada, incluyendo así a los familiares de la víctima.

Por ende, las principales características de la desaparición forzada son según Albaladejo (2009):

La desaparición forzada es una violación múltiple y continuada de numerosos derechos humanos, tales como el derecho a la libertad y seguridad personal, el derecho a la integridad personal, a un trato humano y a la prohibición de la tortura, el derecho al debido proceso, a un recurso efectivo y a las garantías judiciales, y el derecho a la vida. Se entiende que es un delito continuado y permanente, es decir, que el delito se sigue cometiendo todos los días desde la desaparición de la persona hasta que se establezca el destino o paradero de la misma. Es un delito imprescriptible, lo que supone que el delito y la acción penal derivada del mismo no desaparecen por el paso del tiempo (p. 4). 
Percepción de reparación en familias de víctimas de desaparición forzada | 39

El proceso de desmovilización paramilitar en el contexto reciente, reparación integral y origen de la Ley 975 de Justicia y Paz

A lo largo de la historia de Colombia se han aprobado una serie de normativas encaminadas a intentar buscar la paz a través de negociaciones con aquellos grupos armados al margen de la ley.

El Congreso de la República, aprobó el 22 de junio del año 2005, durante el mandato de Álvaro Uribe Vélez, la ley de Justicia y Paz o ley 975 de 2005, cuya finalidad es administrar el proceso de desmovilización de las estructuras paramilitares y a futuro para otros grupos armados. En aplicación de dicha ley están siendo procesados 3.442 de un total de 30.000 miembros paramilitares que participaron en los procesos de desmovilización llevados a cabo entre el año 2002 y el 2006; según las cifras de la Oficina del Alto Comisionado de Paz en el 2009, de este total cerca de 50 desmovilizados están encarcelados y 14 extraditados, mientras que de los demás se desconoce su paradero (Quintero, 2010).

Según el cuarto informe rendido por el Observatorio Internacional (OI) sobre DDR y la Ley de Justicia y Paz, la implementación de la Ley 975 de 2005 no carece de antecedentes en Colombia. Concebir a la víctima como sujeto procesal, reconociendo los derechos que le son propios, no es una iniciativa del procedimiento penal especial en el marco de Justicia y Paz. Por ejemplo "desde el año 2002, la Corte Constitucional se había pronunciado en Colombia, en sentencia $\mathrm{N}^{\circ} \mathrm{C}-228$, en el sentido de reconocerle a las víctimas, además del derecho a la reparación económica, los derechos a la verdad y a la justicia en cada caso concreto" (Observatorio Internacional sobre el proceso de DDR y la Ley de Justicia y Paz, 2011). 
Percepción de reparación en familias de víctimas de desaparición forzada 40

De acuerdo con Albaladejo (2009), en Colombia existen en la actualidad dos procedimientos penales para la investigación y sanción de los delitos de desaparición forzada, los cuales son:

1. Procedimiento penal ordinario, aplicable a todos los casos de desaparición forzada, con independencia de quienes sean los autores o las víctimas. Su procedimiento ha sido objeto de reforma a través de la instauración de un nuevo sistema llamado "sistema penal acusatorio", el cual otorga un papel destacado a la víctima y a sus derechos. El marco normativo procesal está compuesto en la actualidad por dos leyes principales: Ley 600 de 2000 y Ley 906 de 2004 que expide el nuevo Código de Procedimiento Penal.

2. Procedimiento en el marco de la Ley de Justicia y Paz, aplicable cuando los hechos sean cometidos por grupos armados al margen de la ley, cuyos miembros se han desmovilizado colectiva o individualmente, y se han acogido al procedimiento penal que dicha ley establece. La Ley 975 de 2005, conocida comúnmente como Ley de Justicia y Paz, establece un modelo para la persecución de los delitos entre ellos la desaparición forzada de personas. En el marco de la Ley 975 las investigaciones son responsabilidad de la Unidad Nacional para la justicia y la paz de la Fiscalía General de la Nación.

A fin de intervenir en las investigaciones que adelanta la Unidad Nacional de Fiscalías para la Justicia y la Paz, la víctima o el familiar de la persona desaparecida forzosamente debe solicitar y diligenciar en su totalidad el formato de "Registro de hechos atribuibles a los miembros de los grupos armados al margen de la ley", así como el "Formato nacional para la búsqueda de las personas desaparecidas”, presentándolos ante la Unidad, los grupos satélites o 
Percepción de reparación en familias de víctimas de desaparición forzada | 41 ante la Procuraduría General de la Nación, la Defensoría del Pueblo, las personerías municipales o la Comisión Nacional de Reparación y Reconciliación.

La entrega y el diligenciamiento de ambos formatos son gratuitos. Los funcionarios de las instituciones competentes deben brindar a la víctima y a sus familiares la asesoría necesaria para el diligenciamiento de estos formularios (Albaladejo, 2009 p. 13).

\section{Reparación integral}

Ahora bien, en materia de reparación integral es posible identificar algunas leyes y decretos sobre los cuales es importante hacer una breve revisión estableciendo las posibilidades de reparación integral de las víctimas desde el panorama de las posibilidades legales para su realización efectiva; estas son: la Ley 418 de 1997 y 782 de 2002, la Ley 589 de 2000, la Ley 971 de 2005, la Ley 975 de 2005 o Ley de Justicia y Paz, el Decreto 1290 de 2008 o de Reparación por Vía Administrativa, el decreto 929 de 2007, el Decreto 3391 de 2006, el Decreto 315 de 2007 y la Ley de Víctimas: ley 1448/11, sin embargo para el presente proyecto se profundizaran en los determinados por la ley 975/05 y la Ley 1448/11.

Cabe mencionar una oportuna recomendación realizada por la Procuraduría General de la Nación (2009) en el informe: Valoración de los programas oficiales de atención a las víctimas del conflicto armado interno en Colombia, citado por Jiménez (2010), en el que hacen un llamado a pasar de brindar una atención netamente psicojurídica a bridar una intervención psicosocial a las víctimas del conflicto armado, en el sentido de garantizar una atención integral a las mismas independientemente de si se inicia o no un proceso judicial, basado en la necesidades de las víctimas y no de los procedimientos judiciales o administrativos.

Los avances en materia de reparación integral para las víctimas y sus familiares, no dependen exclusivamente de los instrumentos legales que regulan la actuación de las autoridades 
Percepción de reparación en familias de víctimas de desaparición forzada 42 responsables de garantizar el acceso a la justicia, sino también de la voluntad política de los actores del conflicto, por ello resulta complicado ver materializados en todos los casos los componentes de la reparación.

Hoy en día el posible alcance en materia de reparación de las víctimas de desaparición forzada surge de lo anotado en la resolución A/RES/60/147 de los principios y directrices básicos sobre el derecho de las víctimas de violaciones manifiestas de las normas internacionales de derechos humanos y de violaciones graves del derecho internacional humanitario a interponer recursos y obtener reparaciones, aprobada por la Asamblea General de las Naciones Unidas (2006), que define los principios de reparación integral, a saber, la restitución, la indemnización, la rehabilitación, la satisfacción y las garantías de no repetición, resumidos en la siguiente tabla:

Tabla 1

Principios de reparación

\section{Forma de}

reparación *

\section{Definición}

Siempre que sea posible, ha de devolver a la víctima a la situación anterior a la violación manifiesta de las normas internacionales de derechos humanos o la La violación grave del derecho internacional humanitario. La restitución comprende, restitución según corresponda, el restablecimiento de la libertad, el disfrute de los derechos humanos, la identidad, la vida familiar y la ciudadanía, el regreso a su lugar de residencia, la reintegración en su empleo y la devolución de sus bienes. 


\section{(...continuación) Tabla 1}

\section{Principios de reparación}

Ha de concederse, de forma apropiada y proporcional a la gravedad de la violación y a las circunstancias de cada caso, por todos los perjuicios económicamente evaluables que sean consecuencia de violaciones manifiestas de las normas internacionales de derechos humanos o de violaciones graves del derecho internacional humanitario, tales como los siguientes:

La $\quad$ a) El daño físico o mental;

indemnización b) La pérdida de oportunidades, en particular las de empleo, educación y prestaciones sociales;

c) Los daños materiales y la pérdida de ingresos, incluido el lucro cesante;

d) Los perjuicios morales;

e) Los gastos de asistencia jurídica o de expertos, medicamentos y servicios médicos y servicios psicológicos y sociales.

\footnotetext{
La Ha de incluir la atención médica y psicológica, así como servicios jurídicos y rehabilitación sociales.
} 


\section{(...continuación) Tabla 1}

\section{Principios de reparación}

Ha de incluir, cuando sea pertinente y procedente, la totalidad o parte de las medidas siguientes:

a) Medidas para conseguir que no continúen las violaciones;

b) Verificación de los hechos y la revelación pública y completa de la verdad, en la medida en que esa revelación no provoque más daños

c) La búsqueda de las personas desaparecidas, de las identidades de los niños secuestrados y de los cadáveres de las personas asesinadas, y la ayuda para recuperarlos, identificarlos y volver a inhumarlos según el deseo explícito o presunto de la víctima o las prácticas culturales de su familia y comunidad;

La d) Una declaración oficial o decisión judicial que restablezca la dignidad, la satisfacción reputación y los derechos de la víctima y de las personas estrechamente vinculadas a ella;

e) Una disculpa pública que incluya el reconocimiento de los hechos y la aceptación de responsabilidades;

f) La aplicación de sanciones judiciales o administrativas a los responsables de las violaciones;

g) Conmemoraciones y homenajes a las víctimas;

h) La inclusión de una exposición precisa de las violaciones ocurridas en la enseñanza de las normas internacionales de derechos humanos y del derecho internacional humanitario, así como en el material didáctico a todos los niveles. 
(...continuación) Tabla 1

Principios de reparación

a) Control efectivo por las autoridades civiles sobre las fuerzas armadas y de seguridad;

b) La garantía de que todos los procedimientos civiles y militares se ajustan a las normas internacionales relativas a las garantías procesales, la equidad y la imparcialidad;

c) El fortalecimiento de la independencia del poder judicial;

d) La protección de los profesionales del derecho, la salud y la asistencia sanitaria, la información y otros sectores conexos, así como de los defensores

Las garantías de de los derechos humanos;

no repetición e) La educación de todos los sectores de la sociedad respecto de los derechos humanos y del derecho internacional humanitario

f) La promoción de la observancia de los códigos de conducta y de las normas éticas, en particular las normas internacionales;

g) La promoción de mecanismos destinados a prevenir, vigilar y resolver los conflictos sociales;

h) La revisión y reforma de las leyes que contribuyan a las violaciones manifiestas de las normas internacionales de derechos humanos y a las violaciones graves del derecho humanitario o las permitan.

\footnotetext{
* Tomado de la resolución A/RES/60/147 Asamblea General de las Naciones Unidas (2006).
}

Es así, que a nivel internacional se ha establecido, de un lado la obligación de los Estados de garantizar las medidas tendientes a obtener reparación y de otro, el derecho de la víctima a 
recibir dicha reparación. Esta afirmación encuentra respaldo en el artículo 25 de la Convención Americana de Derechos Humanos y en el artículo 2.3 a) del Pacto Internacional de Derechos Civiles y Políticos.

En este sentido Beristain. C (2006) establece alrededor del concepto de reparación integral que: "El derecho a la reparación está basado tanto en términos morales como legales, a través de una creciente legislación y tratados internacionales que apoyan este derecho. En ellos se formulan cinco dimensiones de reparaciones plasmadas en un documento de las Naciones Unidas sobre los derechos de las víctimas y la responsabilidad del Estado”.

Asimismo, Beristain, C (2006) cita a Magarrell (2004) donde él manifiesta que:

Las políticas de reparación responden a dos finalidades principales: primero el reconocimiento de la dignidad y el estatus de víctimas como tales, como personas y grupos merecedores del pleno respeto y goce de sus derechos. La otra finalidad es el establecimiento - en algunos casos por primera vez - de relaciones de confianza cívica y solidaridad con las víctimas. A través de las reparaciones, las víctimas ven una manifestación concreta de que tienen derechos y serán respetados por sus conciudadanos y por el Estado mismo. (De Grieff, 2005). El conjunto de las políticas orientadas a la reparación incluye modificaciones legislativas, programas específicos para un amplio abanico de necesidades, memoriales y conmemoraciones, además de la reparación económica y pensiones, de forma que se atiendan globalmente a los diferentes grupos de afectados, p 69 .

Por su parte, la Comisión de Derechos Humanos (2005) en el Consejo Económico y Social de las Naciones Unidas refiere que el derecho de las víctimas a obtener reparación frente a violaciones manifiestas de derechos humanos comprende todos los daños y perjuicios sufridos 
Percepción de reparación en familias de víctimas de desaparición forzada 47

por las víctimas; así como medidas de restitución, indemnización, rehabilitación y satisfacción según lo establece el derecho internacional. En los casos de desapariciones forzadas, la familia de la víctima directa tiene el derecho imprescriptible a ser informada de la suerte y/o el paradero de la persona desaparecida y, en caso de fallecimiento, se le debe restituir el cuerpo en cuanto se identifique, independientemente de que se haya establecido la identidad de los autores o se los haya encausado.

La Comisión de Derechos Humanos de las Naciones Unidas (2005), en su resolución 2005/35 estableció los principios y directrices básicos sobre el derecho de las víctimas de violaciones manifiestas a las normas internacionales de derechos humanos y de violaciones graves del derecho internacional humanitario, a interponer recursos y a obtener reparaciones. Para precisar el tema de la reparación, se estableció que:

“Una reparación adecuada, efectiva y rápida tiene por finalidad promover la justicia, remediando las violaciones manifiestas de las normas internacionales de derechos humanos o las violaciones graves del derecho internacional humanitario. La reparación ha de ser proporcional a la gravedad de las violaciones y al daño sufrido. Conforme a su derecho interno y a sus obligaciones jurídicas internacionales, los Estados concederán reparación a las víctimas por las acciones u omisiones que puedan atribuirse al Estado y constituyan violaciones manifiestas de las normas internacionales de derechos humanos o violaciones graves del derecho internacional humanitario. Cuando se determine que una persona natural o jurídica u otra entidad está obligada a dar reparación a una víctima, la parte responsable deberá conceder reparación a la víctima o indemnizar al Estado si éste hubiera ya dado reparación a la víctima”. 
Concretamente, al hacer referencia al derecho a la reparación, la ley 975 de 2005 establece en su artículo 8: El derecho de las víctimas a la reparación comprende las acciones que propendan por la restitución, indemnización, rehabilitación, satisfacción; y las garantías de no repetición de las conductas.

Restitución es la realización de las acciones que propendan por regresar a la víctima a la situación anterior a la comisión del delito.

La indemnización consiste en compensar los perjuicios causados por el delito.

La rehabilitación consiste en realizar las acciones tendientes a la recuperación de las víctimas que sufren traumas físicos y sicológicos como consecuencia del delito.

La satisfacción o compensación moral consiste en realizar las acciones tendientes a restablecer la dignidad de la víctima y difundir la verdad sobre lo sucedido.

Las garantías de no repetición comprenden, entre otras, la desmovilización y el desmantelamiento de los grupos armados al margen de la ley.

Se entiende por reparación simbólica toda prestación realizada a favor de las víctimas o de la comunidad en general que tienda a asegurar la preservación de la memoria histórica, la no repetición de los hechos victimizantes, la aceptación pública de los hechos, el perdón público y el restablecimiento de la dignidad de las víctimas.

La reparación colectiva debe orientarse a la reconstrucción psico-social de las poblaciones afectadas por la violencia. Este mecanismo se prevé de manera especial para las comunidades afectadas por la ocurrencia de hechos de violencia sistemática.

Otro concepto importante frente a reparación integral es el que propone la Ley 1448 de 2011 en su artículo 69 y siguientes: 
Percepción de reparación en familias de víctimas de desaparición forzada 49

Artículo 69. Medidas de reparación. Las víctimas de que trata esta ley, tienen derecho a obtener las medidas de reparación que propendan por la restitución, indemnización, rehabilitación, satisfacción y garantías de no repetición en sus dimensiones individual, colectiva, material, moral y simbólica. Cada una de estas medidas será implementada a favor de la víctima dependiendo de la vulneración en sus derechos y las características del hecho victimizante.

Artículo 70. El Estado colombiano, a través del Plan Nacional para la Atención y Reparación Integral a las Víctimas, deberá adoptar un programa integral dentro del cual se incluya el retorno de la víctima a su lugar de residencia o la reubicación y la restitución de sus bienes inmuebles.

\section{Desarrollo del concepto de Percepción}

Una vez abordados los conceptos de víctima, victimización, reparación integral, revictimización, daño psicosocial y el contexto de la investigación, es posible pasar a identificar y definir el concepto percepción de reparación que tienen las víctimas, pero primero, se hace un abordaje del concepto de percepción desde la psicología para luego desplegar su concepto en el contexto legal.

El estudio del concepto de percepción ha contribuido a denominar a la psicología como ciencia, siendo el movimiento Gestalt uno de los pioneros en establecer sus principios explicativos. Este movimiento de origen alemán, impulsado por Wertheimer, Koffka y Köhler, durante las primeras décadas del siglo $\mathrm{XX}$, ha considerado la percepción como el proceso fundamental de la actividad mental y establece que las demás actividades psicológicas como el aprendizaje, la memoria y el pensamiento, dependen del adecuado funcionamiento del proceso de organización perceptual. Como aporte crucial para la psicología, la escuela Gestalt rompe 
Percepción de reparación en familias de víctimas de desaparición forzada $\mid 50$

esquemas al considerar a la percepción como un proceso primordial de la actividad mental y no un derivado cerebral de estados sensoriales, es decir que la actividad mental no es una copia idéntica del mundo percibido y en vez de ello, entiende a la percepción como un proceso selectivo que extrae información relevante, dando como resultado un estado de claridad y lucidez de la conciencia que permite el desempeño dentro del mayor grado de racionalidad y coherencia posibles con el mundo circundante (Oviedo, 2004).

Desde otra perspectiva, la percepción es entendida como un proceso biocultural, que involucra estímulos físicos, sensaciones y su subsecuente selección y organización. De esta manera, las experiencias sensoriales se interpretan y adquieren significado al ser moldeadas por pautas culturales e ideológicas aprendidas desde la infancia. En términos generales, la percepción es el proceso cognitivo de la conciencia que consiste en el reconocimiento, interpretación y significación para la elaboración de juicios en torno a las sensaciones obtenidas del ambiente físico y social, en el que intervienen otros procesos psíquicos entre los que se encuentran el aprendizaje, la memoria y la simbolización (Vargas-Melgarejo, 1994).

Otra postura frente al concepto de percepción es la de Guski (1992) quien explica que la percepción es el conocimiento sensible, es el reflejo de la realidad en la conciencia de los hombres, que es transmitida a través de unos órganos sensoriales y a través de la actividad nerviosa (p. 13). Este autor también explica los factores internos que afectan la percepción como diferentes estados perceptivos. Por un lado, está la motivación, que son las necesidades que hacen variar nuestras percepciones. Las instrucciones y el contexto influyen en nuestro estado perceptivo; las expectativas e incentivos motivacionales; los factores culturales, las creencias y costumbres; las recompensas y castigo; las emociones, que son las respuestas psicogalvánicas de la piel (Guski, 1992). 
Percepción de reparación en familias de víctimas de desaparición forzada $\mid 51$

Teniendo en cuenta las anteriores definiciones se puede distinguir otros tipos de percepción. Así, la percepción social es la que hace referencia a la valoración que un individuo hace de una determinada situación social y de su papel o posibilidades en ella. Un aspecto importante para la percepción social es el proceso por el cual nos formamos una primera impresión de una persona y establecemos una relación con ella. Incluye aquellos procesos de índole cognitivo mediante los cuales elaboramos juicios relativamente elementales acerca de otras personas (Bruner y Tagiuri, 1954).

Otra postura frente aquella valoración o captación que cada sujeto realiza en una situación de interacción social es la propuesta por Munné (1989) quien afirma:

"La teoría de la atribución se refiere a la percepción de la causalidad de la conducta social. Se basa en el análisis ingenuo de la acción. El hombre atribuye lo que ocurre en su ambiente a unos factores causantes determinados y esta explicación causal de las acciones, ya sean propias o de los otros, influye en su conducta en tanto que contribuye al significado de ésta y por lo mismo a su posible predicción y control." (pág. 193).

Otro de los aportes al estudio de la percepción es el realizado por Bruner, quien hizo un gran esfuerzo por demostrar la influencia que tienen las variables cognitivas y motivacionales en la percepción. Desde este punto de vista, distingue tres fases en la percepción: 1) Una fase preperceptiva, en la que el sujeto está a la expectativa de un determinado acontecimiento, llevado por sus esquemas intelectuales o motivacionales. 2) La fase de la recepción de la información. 3) La fase de evaluación de las hipótesis perceptivas, en la que el sujeto juzga la adecuación existente entre sus expectativas anteriores y la información recibida. Si las hipótesis se confirman, estamos en presencia de un nuevo precepto. Si no se confirman, se formulan nuevas 
Percepción de reparación en familias de víctimas de desaparición forzada $\mid 52$

hipótesis. Algunas veces, si los objetos percibidos no corresponden con las expectativas del sujeto, se generan distorsiones perceptivas, sobrevalorando las características que se corresponden con las expectativas del perceptor. La percepción se asienta pues sobre la formulación de hipótesis y sobre la toma de decisiones, influyendo en ella las necesidades, valores y deseos del sujeto (Oyarbide, 2004).

De acuerdo a lo anterior, varios fenómenos sociales, incluidos los que tienen lugar en el ámbito psicojurídico pueden abordarse desde el estudio de la percepción, en este sentido la presente investigación hace una aproximación a lo que perciben y esperan las familias participantes frente a las alternativas de reparación en su caso particular, percepción que se ha visto influenciada por los daños psicológicos y psicosociales encontrados como consecuencia de la desaparición forzada de los seres queridos y por el impacto del proceso judicial adelantado, en el que se descubren situaciones de revictimización..

Ahora bien, la utilización del concepto de reparación según Guillis (2001) en el ámbito de la justicia o de los procesos de reparación, se da por la vía de una medida externa, en donde se ubica la culpa en el plano concreto y no en el imaginario propio. Es decir, con una medida o con un acto, el perpetrador o culpable da un libre testimonio donde reconoce su culpabilidad a través, por ejemplo, de la entrega de un bien que puede tener efectos reparadores en su víctima. Que ese acto tenga efectos reparadores dependerá de la significación que la víctima le pueda otorgar a esa medida y de su capacidad para integrarla a su proceso de reconstrucción de su proyecto de vida, en otras palabras sería que esos actos de reparación están expuestos a la relación absolutamente singular que puede establecer la victima entre lo que la reparación ofrece, y aquello que ha perdido. 
Percepción de reparación en familias de víctimas de desaparición forzada $\mid 53$

En este sentido, Guilis (2001) habla de que toda reparación es simbólica cuando entendemos que esta pretende una compensación que transforma el daño real a un acto de justicia o a una medida concreta de indemnización, y pretende representarlo en magnitud cualitativa o cuantitativa, pero nunca podrá reparar el daño real producido sobre la víctima.

Esta naturaleza simbólica de la reparación es la que permite a las victimas hacer una elaboración singular a partir de lo que ellas sufrieron con lo perciben sobre aquello que se les ha entregado o se les entregará, brindándoles la posibilidad de construir otras significaciones más allá de lo otorgado para continuar con sus proyectos de vida, siendo éste el trabajo importante para los profesionales psicosociales.

Por otro lado, se establece que las víctimas esperan de la reparación una manifestación más tangible de los esfuerzos del Estado por remediar el daño que han sufrido, pero para ello, se requiere avanzar tanto en los criterios para hacer que sea más positiva y esté adaptada a las necesidades de las víctimas, respondiendo a su cumplimiento efectivo. Por otra parte, para el Estado la reparación es percibida como una oportunidad de integrar a las víctimas en la sociedad, pero también de prevenir nuevas violaciones en el futuro (Beristain, 2008).

\section{Marco normativo en el contexto nacional e internacional sobre desaparición forzada}

A nivel internacional la desaparición forzada de personas es un delito que particularmente contraviene los artículos 3, 5, 8, 9 y 10 de la Declaración Universal que consagran los derechos a la vida, la libertad y la seguridad, (Arias y Muñoz, 2008)

La Asamblea General de la ONU el 18 de diciembre de 1992 promulgo la Declaración sobre la Protección de Todas las Personas contra las Desapariciones Forzosas en la que se establece que "(...) las desapariciones forzosas afectan los valores más profundos de toda sociedad respetuosa de la primacía del derecho, de los Derechos Humanos y de las libertades 
Percepción de reparación en familias de víctimas de desaparición forzada $\mid 54$

fundamentales, y que su práctica sistemática representa un crimen de lesa humanidad". Como se mencionó en líneas anteriores, dicha Declaración también define quienes son las víctimas del delito de la desaparición forzada.

El artículo 3 de los Convenios de Ginebra establece que en casos de conflictos armados que no sean de índole internacional, las partes en conflicto deberán abstenerse de atentar contra la vida, la integridad corporal y la dignidad personal. Adicionalmente detalla las normas referidas a las personas desaparecidas, que afirman el derecho de las familias a ser informadas sobre el paradero de sus familiares desaparecidos; la obligación de las partes en conflicto a buscar a las personas desaparecidas, establecer responsabilidades, intercambiar información sobre la ubicación de las sepulturas; de respetar, conservar y marcar dichas sepulturas y proporcionar información sobre las personas que se encuentran sepultadas (Arias y Muñoz, 2008).

Según el artículo 7 del Estatuto de Roma de la Corte Penal Internacional la desaparición forzada de personas se considera como un crimen de lesa humanidad y también la define tal como se anotó en párrafos anteriores. El artículo 8 del Estatuto tipifica como crímenes de guerra las infracciones graves a los Convenios de Ginebra, entre ellas, matar intencionalmente, someter a una persona a tortura $\mathrm{u}$ otros tratos inhumanos, infligir deliberadamente grandes sufrimientos, atentar gravemente contra la integridad física o la salud y cometer ultrajes contra la dignidad de la persona.

Tras las desapariciones forzadas surgidas en muchos países de América Latina se adoptaron mecanismos vinculantes para los Estados miembros de la Organización de Estados Americanos (OEA), la cual aprobó la Convención Interamericana Sobre Desaparición Forzada de Personas el 9 de junio de 1994. Este instrumento compromete a los Estados a que prevengan, 
Percepción de reparación en familias de víctimas de desaparición forzada | 55

sancionen, erradiquen y promulguen leyes para adoptar medidas administrativas y judiciales que permitan aplicarla. Así mismo, los obliga a que no se practique, permita o tolere la desaparición forzada. En Colombia, se ratificó mediante la Ley 797 de noviembre de 2001 (Arias y Muñoz, 2008).

A nivel mundial se promulgó la Convención Internacional para la Protección de Todas las Personas contra la Desaparición Forzada por parte del Consejo de Derechos Humanos de las Naciones Unidas y por la Asamblea General de las Naciones Unidas, que para entrar en vigor requirió su ratificación por 20 Estados (Asamblea General de las Naciones Unidas, 2006).

Por otra parte la Constitución Política de la República de Colombia , 1991, prohibió de manera expresa en su artículo 12 la desaparición forzada, norma que tuvo posterior desarrollo legal a través de la Ley 589 del 2000, donde se tipificó la conducta como delito, así como la Ley 971 del 2005, que reglamentó el mecanismo de búsqueda urgente.

En años recientes la Ley de Justicia y Paz fue aprobada por el Congreso en junio de 2005, marco legal que según Amnistía Internacional, no cumple las normas internacionales sobre el derecho de las víctimas a la verdad, la justicia y la reparación; además, agravará el problema endémico de la impunidad en Colombia, y entraña el peligro de que los paramilitares desmovilizados se reintegren en el conflicto armado (Amnistía Internacional, 2005).

La Ley de Justicia y Paz, fijó como pena máxima ocho años, la cual resulta efímero comparado con otros procesos de justicia transicional en el mundo (Arias y Muñoz, 2008).

La precaria implementación de la reparación por parte del Estado colombiano obliga a las comunidades víctimas a acudir a mecanismos legales internacionales para hacer valer sus derechos. En este sentido, la Corte Interamericana de Derechos Humanos tiene competencia jurisdiccional en Colombia por lo que la Corte Constitucional ha reconocido su jurisprudencia en 
Percepción de reparación en familias de víctimas de desaparición forzada 56

el derecho interno. Hasta el momento la Corte Interamericana de Derechos Humanos ha proferido alrededor de 12 sentencias condenatorias relacionadas con múltiples delitos como homicidio, tortura o desplazamiento forzado, 3 de ellas específicamente relacionadas con casos de desaparición forzada, a saber:

Tabla 2

Sentencias condenatorias contra Colombia en casos de desaparición forzada-CIDH*

Caso Resumen de reparaciones

- Fija monto que el Estado de Colombia debe pagar antes del 31 de

julio de 1997 en carácter de reparación a los familiares de Isidro

Caballero Delgado y de María del Carmen Santana.

Caso Caballero - Fija la suma que deberá pagar el Estado directamente a la señora

Delgado y Santana, María Nodelia Parra Rodríguez como resarcimiento de los gastos sentencia de fondo del incurridos en sus gestiones ante las autoridades colombianas.

08 de Diciembre de -Que no proceden las reparaciones no pecuniarias solicitadas.

1995 - Que el Estado de Colombia está obligado a continuar los esfuerzos para localizar los restos de las víctimas y entregarlos a sus familiares.

- Supervisar el cumplimiento de la Sentencia de Reparaciones y Costas y sólo después dará por concluido el caso. 
Percepción de reparación en familias de víctimas de desaparición forzada $\mid 57$

\section{(...continuación) Tabla 2}

Sentencias condenatorias contra Colombia en casos de desaparición forzada-CIDH

Caso de los 19 Comerciantes, sentencia de fondo del 05 de julio de 2004.
- La Sentencia de Fondo, Reparaciones y Costas constituye per se una forma de reparación.

- El Estado debe investigar efectivamente los hechos del presente caso, con el fin de identificar, juzgar y sancionar a todos los autores materiales e intelectuales de las violaciones cometidas en perjuicio de los 19 comerciantes y que el resultado de este proceso deberá ser públicamente divulgado.

- El Estado debe efectuar, una búsqueda seria, en la cual realice todos los esfuerzos posibles para determinar con certeza lo ocurrido con los restos de las víctimas y, en caso de ser posible, para entregarlos a sus familiares

- El Estado debe erigir un monumento en memoria de las víctimas y, mediante una ceremonia pública y en presencia de los familiares de las víctimas, debe poner una placa con los nombres de los 19 comerciantes.

- El Estado debe realizar un acto público de reconocimiento de su responsabilidad internacional en relación con los hechos de este caso

- El Estado debe brindar gratuitamente, el tratamiento médico y psicológico requerido por los familiares de las víctimas.

- El Estado debe establecer todas las condiciones necesarias para que los miembros de la familia de la víctima Antonio Flórez Contreras que están en el exilio puedan regresar a Colombia, si así lo desean, y debe cubrir los gastos en que incurran por motivo del traslado.

- El Estado debe ocuparse particularmente de garantizar la vida, integridad y seguridad de las personas que rindieron declaración ante el Tribunal y sus familias.

- El Estado debe pagar por concepto de los ingresos dejados de percibir por cada una de las 19 víctimas.

- El Estado debe pagar por concepto de los gastos en que incurrieron los familiares de las víctimas, con el fin de indagar el paradero de éstos.

- El Estado debe pagar por concepto de indemnización del daño inmaterial de cada una de las 19 víctimas.

- El Estado debe pagar por concepto de indemnización del daño inmaterial ocasionado a los familiares de las víctimas

- Que el Estado debe pagar por concepto de costas y gastos a la Comisión Colombiana de Juristas y al Centro por la Justicia y el Derecho Internacional (CEJIL).

- El Estado deberá rendir a la Corte un informe sobre las medidas tomadas para darle cumplimiento. 


\section{(...continuación) Tabla 2}

\section{Sentencias condenatorias contra Colombia en casos de desaparición forzada-CIDH}

- La Sentencia de Fondo, Reparaciones y Costas constituye per se una forma de reparación. - El Estado debe realizar inmediatamente las debidas diligencias para activar y completar eficazmente, en un plazo razonable, la investigación para determinar la responsabilidad de todos los partícipes en la masacre, así como la de quienes hubiesen sido responsables por acción o por omisión del incumplimiento de la obligación estatal de garantizar los derechos violados.

- El Estado debe adoptar las medidas pertinentes para que las violaciones a los derechos humanos cometidas sean efectivamente investigadas en procesos en los que se otorguen todas las garantías judiciales, con el fin de evitar la repetición de hechos tan graves como los que ocurrieron en la masacre de Pueblo Bello.

- El Estado debe informar a la Corte cada seis meses sobre las medidas adoptadas y los resultados obtenidos. - El Estado debe adoptar inmediatamente las medidas pertinentes para buscar e identificar a las víctimas desaparecidas, así como para entregar los restos mortales a sus familiares y cubrir los gastos de entierro de aquéllos, en un plazo razonable. Para estos efectos, deberá completar las acciones emprendidas para recuperar los restos de las personas desaparecidas, así como cualesquiera otras que resulten necesarias, para lo cual deberá emplear todos los medios técnicos y científicos posibles, tomando en cuenta las normas internacionales pertinentes en la materia. - El Estado debe garantizar que, independientemente de las acciones específicas señaladas en el punto resolutivo anterior, las entidades oficiales correspondientes hagan uso de dichas normas internacionales como parte de su instrumental para efectos de la búsqueda e identificación de personas desaparecidas o privadas de la vida. - El Estado debe proveer un tratamiento médico o psicológico, según sea el caso, a todos los familiares de las 37 personas desaparecidas y de las seis privadas de la vida que lo

Caso Masacre de Pueblo 31 de enero de 2006 Bello, sentencia de fondo de requieran, a partir de la notificación de la Sentencia de Fondo por el tiempo necesario. - El Estado deberá realizar las acciones necesarias para garantizar las condiciones de seguridad para que los familiares de las personas desaparecidas y privadas de la vida, así como otros ex pobladores de Pueblo Bello, que se hayan visto desplazados, puedan regresar.

- El Estado debe realizar, en el plazo de un año, contado a partir de la notificación de la Sentencia de Fondo, Reparaciones y Costas, un acto de disculpa pública y reconocimiento de responsabilidad internacional, como consecuencia de las faltas del Estado a sus deberes de prevención, protección e investigación, así como por las violaciones a los derechos de acceso a la justicia, protección judicial y garantías judiciales cometidas en su perjuicio. - El Estado debe construir, en el plazo de un año, contado a partir de la notificación de la Sentencia de Fondo, Reparaciones y Costas, un monumento apropiado para recordar los hechos

- El Estado debe publicar, dentro del plazo de seis meses, contado a partir de la notificación de la Sentencia de Fondo, Reparaciones y Costas, por una vez, en el Diario Oficial y en otro diario de circulación nacional, la sección de esta Sentencia denominada Hechos Probados, sin las notas al pie de página correspondientes, así como la parte resolutiva de la misma. - El Estado debe pagar las cantidades fijadas en el Anexo I de la Sentencia de Fondo, Reparaciones y Costas, a favor de los familiares de las personas desaparecidas y privadas de la vida, por daño material. - El Estado debe pagar las cantidades fijadas en el Anexo II de la Sentencia de Fondo, Reparaciones y Costas, a favor de los familiares de las personas desaparecidas y privadas de la vida, por daño inmaterial. - La Corte supervisará el cumplimiento íntegro de Sentencia de Fondo, Reparaciones y Costas y dará por concluido el presente caso una vez que el Estado haya ejecutado lo dispuesto en la misma. Dentro del plazo de un año, contado a partir de la notificación de la Sentencia de Fondo, Reparaciones y Costas, el Estado deberá rendir a la Corte un informe sobre las medidas adoptadas para darle acatamiento.

*Tomadas de las fichas técnicas de los casos contenciosos de la Corte Interamericana de Derechos Humanos. 
Percepción de reparación en familias de víctimas de desaparición forzada 59

\section{Estudios nacionales e internacionales}

Al momento de iniciar la búsqueda de trabajos investigativos en el tema del delito de desaparición forzada y los impactos psicosociales que sufren las víctimas al afrontar estos hechos violentos encontramos escasas experiencias escritas y sistematizadas que nos pudieran ayudar a construir la metodología para el desarrollo de una investigación científica. Sin embargo encontramos que a nivel latinoamericano se han llevado algunas investigaciones en materia de las afectaciones psicosociales en víctimas de desaparición forzada y otros delitos sociopolíticos.

Para el caso de México, se ha documentado el caso de Rosendo Radilla víctima de desaparición forzada donde:

Este trabajo buscó conocer el impacto psicosocial de la desaparición forzada de Rosendo Radilla en sus familiares (esposa, hijos y nietos) y en la comunidad, considerando que se trata de un líder comunitario, en el marco de la práctica sistemática de la desaparición forzada como modalidad represiva. Al mismo tiempo, la presente investigación busca conocer el impacto psicosocial de la impunidad a nivel familiar y comunitario en el caso de la desaparición forzada de Rosendo Radilla. A partir de la valoración del daño, con este trabajo buscamos establecer de manera participativa, con los familiares de Rosendo Radilla, una serie de medidas para la reparación integral del daño en los tres niveles: individual, familiar y comunitario (Antillón, 2008, p. 43).

Por otro lado, en Chile también se han desarrollado investigaciones relacionadas con el delito de desaparición forzada, tales como la realizada por Cabanillas (2005), quien desarrolla una investigación teniendo como objetivo exponer la desaparición forzada como modalidad represiva central en la guerra psicológica desarrollada por la dictadura militar de Pinochet en Chile (1973-1990) y analizar sus efectos en la sociedad chilena a través del concepto de trauma 
psicosocial, en un contexto de impunidad concluyendo que esta dictadura configuró un trauma psicosocial durante el período dictatorial que se reactiva ante las actuales condiciones de impunidad de la mayoría de los crímenes de desaparición forzada.

En Guatemala, Gómez (2009) estructura un libro donde brinda como resultado de un esfuerzo de varios años concluyendo en la reflexión y construcción de una metodología apropiada para documentar casos de graves violaciones a derechos humanos, asimismo que éstos puedan aportar conocimientos desde la psicología que auxilien al derecho, especialmente en el diseño de metodologías para realizar peritajes psicológicos que documentaran el daño a la integridad mental en casos de delitos de lesa humanidad.

Para Colombia, dentro de los trabajos de grado universitarios de pregrado y posgrado se han realizado ciertos estudios uno de ellos es el siguiente:

Este trabajo realizado en la Pontificia Universidad Javeriana desde la facultad de Ciencia Política y Relaciones Internacionales, describe y analiza el fenómeno de la Desaparición Forzada en Colombia desde sus inicios en la década de los 70`s hasta la actualidad. Teniendo en cuenta que es un crimen que se viene ejerciendo sistemáticamente por el Estado o por algunos sectores vinculados a este, con el fin de eliminar y disciplinar a la oposición política y a la sociedad en general a pesar de vivir en un sistema político democrático. El desarrollo de este fenómeno no ha tenido el reconocimiento de la sociedad colombiana, así como tampoco el de la academia, especialmente desde la Ciencia Política. Las herramientas teóricas de autores enmarcados dentro del campo de la Teoría Política como Michel Foucault, Hannah Arendt, Giorgio Agamben y Norberto Bobbio, resultan útiles para analizar y estudiar las características y el desarrollo social y político de este fenómeno (Cáceres, 2008, p.7-8). 
Percepción de reparación en familias de víctimas de desaparición forzada 61

Un segundo artículo investigativo realizado en Colombia en la Universidad Autónoma de Bucaramanga por Aguilera (2006) propone una reflexión desde la psicología política; para desarrollar específicamente dos cuestionamientos: 1) ¿cuáles son las secuelas y costos emocionales de los hechos de violencia política tanto en las víctimas directas del conflicto armado como en las familias, la población civil en general y el tejido social? y 2) ¿cómo deben ser abordadas estas secuelas emocionales en una futura propuesta de paz y convivencia? Puesto que es de suma importancia reconocer y visibilizar el daño y el dolor que ha sufrido en medio de la dinámica del conflicto. Asimismo, el artículo propone como base para la convivencia entre los colombianos, que la reconciliación nacional se dé por medio de voluntades libres de sentimientos como el odio y la venganza y no de los acuerdos de paz que se den en el momento.

Recientemente, desde la Maestría en Psicología Jurídica de la Universidad Santo Tomás en una investigación realizada por Suarez y Valdés (2013) se identifican y describen los significados frente al daño psicosocial, el proceso de reparación de las víctimas y el papel de la comunidad frente a este rescatando el papel que tiene el sujeto en la construcción y reconstrucción de la realidad.

Por su parte en diciembre 2006, la Oficina del Alto Comisionado de Naciones Unidas para los Derechos Humanos (OACNUDH), el Comité Internacional de la Cruz Roja (CICR), la Corporación AVRE y el Instituto Interamericano de Derechos Humanos (IIDH) fueron convocados por la Unidad Nacional de Derechos Humanos y Derecho Internacional Humanitario de la Fiscalía General de la Nación (FGN) para tratar el tema del apoyo psicosocial a los familiares de personas desaparecidas. La FGN, insistió en la necesidad de fortalecer la preparación de los fiscales e investigadores para ofrecer una atención adecuada a las víctimas durante todo el proceso, mitigar su dolor durante los procesos de búsqueda, exhumación e 
Percepción de reparación en familias de víctimas de desaparición forzada | 62

identificación, así como proteger al funcionario que realiza el acompañamiento de las víctimas Con esta experiencia se buscaba, además, promover lineamientos para el desarrollo de la atención psicosocial a víctimas, así como la conformación de un espacio interinstitucional entre el personal estatal, las organizaciones no gubernamentales especializadas y las organizaciones de familiares de personas desaparecidas (Oficina del Alto Comisionado de Naciones Unidas para los Derechos Humanos y Comité Internacional de la Cruz Roja, 2009).

A su vez, en Colombia, la Corporación de Desarrollo y Paz del Magdalena Medio CORDEPAZ (2013), desarrolla un protocolo que contiene el sustento teórico, la conceptualización de la desaparición forzada como crimen de lesa humanidad desde un planteamiento jurídico; además, los impactos psicosociales a nivel individual, familiar, comunitario y colectivo. Este tuvo en cuenta la participación de las entidades gubernamentales y no gubernamentales y las normas mínimas de la atención psicosocial a los familiares de los desaparecidos. Posteriormente, establecen los lineamientos generales para la atención en sus diferentes etapas. Dicho protocolo pretende ahondar en la intervención psicosocial, caracterización y plan terapéutico con una propuesta de actividades para implementar según las necesidades de las víctimas. De este protocolo, nace la construcción de un formato de seguimiento y sistematización en la atención a familiares de las víctimas de la desaparición forzada.

Otro trabajo de investigación en relación con el delito de desaparición forzada fue el que se realizó en la Pontificia Universidad Javeriana desde el programa de maestría en política social realizado por Paris. L (2009), donde propone que algunas consideraciones necesarias para la optimización de la política pública en torno a la desaparición forzada en Colombia y recomendaciones para la reparación integral de los familiares sobrevivientes a partir del estudio 
Percepción de reparación en familias de víctimas de desaparición forzada | 63

del proceso de reconocimiento de la desaparición como un problema de interés público, la formulación de soluciones y la implementación de los mecanismos que la legislación ha posibilitado. El estudio evidencia importantes dificultades en el desarrollo de la política pública y significativos avances generados a partir del trabajo de las organizaciones de víctimas y de la sociedad civil en compañía de organismos internacionales y defensores de derechos humanos.

Para finalizar, Ulloque, M (2009) realizan un trabajo para optar al título de maestría en política social de la Pontificia Universidad Javeriana titilado Análisis de la reparación integral desde el marco de la ley 975 de 2005 sobre justicia y paz, estudio de caso (Asociación De Trabajadores Campesinos Del Carare -ATCC-) en donde:

El presente documento está dividido en tres capítulos: El primero busca avanzar en la construcción de un marco conceptual de referencia para el análisis del concepto de reparación integral, reparación colectiva. Seguidamente se explica el concepto de víctima; lo que se entiende por justicia transicional aplicada al caso colombiano desde la jurisprudencia nacional e internacional y el contexto de lo que presenta la ley de justicia y paz. Por último, se presentan las conclusiones del estudio que cabe realizar a la luz del análisis presentado en ambos capítulos sobre el desarrollo de la ley 975 aplicado al caso de la ATCC para lograr una reparación colectiva integral, p. 12-13.

Desde que se ha venido aplicando la justicia transicional a nivel nacional, se han fomentado varios estudios y encuestas para conocer sus avances y las percepciones de los colombianos al respecto, sin embargo estas han sido implementadas en la población en general, a nivel macro, no obstante poco se ha documentado sobre lo que piensan las victimas desde casos puntuales. 
Percepción de reparación en familias de víctimas de desaparición forzada | 64

Por último, los referentes de este documento servirán de base para la construcción de la discusión científica del presente trabajo investigativo que surge a partir de la pregunta central: ¿Cuál es la percepción frente a las alternativas de reparación y su relación con el daño psicosocial y el impacto de los procesos judiciales en dos familias víctimas de desaparición forzada de personas? 
Percepción de reparación en familias de víctimas de desaparición forzada | 65

\section{Objetivos}

\section{Objetivo general}

Describir la percepción frente a las alternativas de reparación integral y su relación con el daño psicosocial y el impacto de los procesos judiciales en dos familias víctimas de desaparición forzada en la ciudad de Barrancabermeja (Santander).

\section{Objetivos específicos}

1. Identificar en los participantes el daño psicológico y psicosocial y su relación con la percepción de las alternativas de reparación integral.

2. Determinar el impacto del proceso judicial y su influencia en la percepción de las alternativas de reparación. 


\section{Conceptualización de categorías y variables}

Teniendo en cuenta la naturaleza de esta investigación de tipo mixto, se analizaron, en principio, las categorías y variables agrupadas de la siguiente manera:

Variables: ansiedad, depresión y trastornos de personalidad (paranoide y evitación)

Categorías: daño psicológico, daño psicosocial (a nivel individual y familiar), percepción de reparación y revictimización.

\section{Variable 1}

Ansiedad. Según el DSM IV los trastornos de ansiedad son un conjunto de categorías diagnosticas que se califican de la siguiente manera: trastornos de angustia sin agorafobia, trastorno de angustia con agorafobia, agorafobia sin historia de trastorno de angustia, fobia específica, fobia social, trastorno obsesivo-compulsivo, trastorno por estrés postraumático, trastorno por estrés agudo, trastorno de ansiedad generalizada, trastorno de ansiedad debido a enfermedad médica, trastorno de ansiedad inducido por sustancias y trastorno de ansiedad no especificado. Estos trastornos pueden manifestarse como crisis de angustia y agorafobia, tal como se describe a continuación:

La crisis de angustia (panic attack) se caracteriza por la aparición súbita de síntomas de aprensión, miedo pavoroso o terror, acompañados habitualmente de sensación de muerte inminente. Durante estas crisis también aparecen síntomas como falta de aliento, palpitaciones, opresión o malestar torácico, sensación de atragantamiento o asfixia y miedo a «volverse loco» o perder el control.

La agorafobia se caracteriza por la aparición de ansiedad o comportamiento de evitación en lugares o situaciones donde escapar puede resultar difícil (o embarazoso), o bien donde sea imposible encontrar ayuda en el caso de que aparezca en ese momento una 
Percepción de reparación en familias de víctimas de desaparición forzada 67

crisis de angustia o síntomas similares a la angustia. American Psychiatric Association. DSM-IV (1995).

Para la medición de esta variable se empleó el Cuestionario de Ansiedad Estado-Rasgo STAI, instrumento que permite evaluar dos conceptos independientes de la ansiedad, la $\underline{\text { Ansiedad }}$ como estado $(A / E)$ entendido como un estado emocional transitorio, caracterizado por sentimientos subjetivos, conscientemente percibidos, de atención y aprensión y por hiperactividad del sistema nervioso autónomo. Por otro lado evalúa la Ansiedad como rasgo $\underline{(A / R})$ que es una propensión ansiosa, relativamente estable, que caracteriza a los individuos con tendencia a percibir las situaciones como amenazadoras (Spielberg, Gorsuch y Lushene, 1982).

\section{Variable 2}

Depresión. Según la Organización Mundial de la Salud, la depresión es un trastorno mental frecuente, que se caracteriza por la presencia de tristeza, pérdida de interés o placer, sentimientos de culpa o falta de autoestima, trastornos del sueño o del apetito, sensación de cansancio y falta de concentración. La depresión puede llegar a hacerse crónica y dificultar el desempeño en el trabajo o la escuela y la capacidad para afrontar la vida diaria. En su forma más grave, puede conducir al suicidio. Si es leve, se puede tratar sin necesidad de medicamentos, pero cuando tiene carácter moderado o grave se pueden necesitar medicamentos y psicoterapia profesional (OMS, 2013).

Según el DSM- IV el trastorno depresivo mayor se caracteriza por uno o más episodios depresivos mayores de al menos 2 semanas de estado de ánimo depresivo o pérdida de interés acompañados por al menos otros cuatro síntomas de depresión). American Psychiatric Association. DSM-IV (1995). 


\section{Variable 3}

Trastornos de personalidad. "Un trastorno de la personalidad es un patrón permanente e inflexible de experiencia interna y de comportamiento que se aparta acusadamente de las expectativas de la cultura del sujeto, tiene su inicio en la adolescencia o principio de la edad adulta, es estable a lo largo del tiempo y comporta malestar o perjuicios para el sujeto" American Psychiatric Association. DSM-IV (1995).

Para el caso de esta investigación se evaluaron las escalas de los trastornos paranoide y de evitación a través del IPDE.

\section{Categoría 1}

Daño psicológico o psíquico. Varios autores definen el daño psicológico haciendo referencia tanto a las lesiones psíquicas (daño agudo) producidas por un delito violento, como a las secuelas emocionales (daño crónico) que persisten en la victima de forma y que interfieren de manera negativa en su vida cotidiana. Se altera la capacidad de afrontamiento y de adaptación de la víctima una nueva situación (Pynoos, Sorensen y Steinberg, 1993 citado en Echeburúa y Corral, 2005). Otra definición adoptada de daño psíquico es la de un perjuicio apropiado para calificar, cuantificar y pronosticar científicamente, es decir que se corrobora su existencia real con técnicas de evaluación válidas y confiables (Navia, 2007 citado en Cañas y Tapias, 2012).

El daño psicológico típico esperado en los familiares víctimas de desaparición forzada de esta investigación y los instrumentos empleados para su identificación se resumen en la siguiente tabla: 
Tabla 3

Categoría 1. Daño psicológico

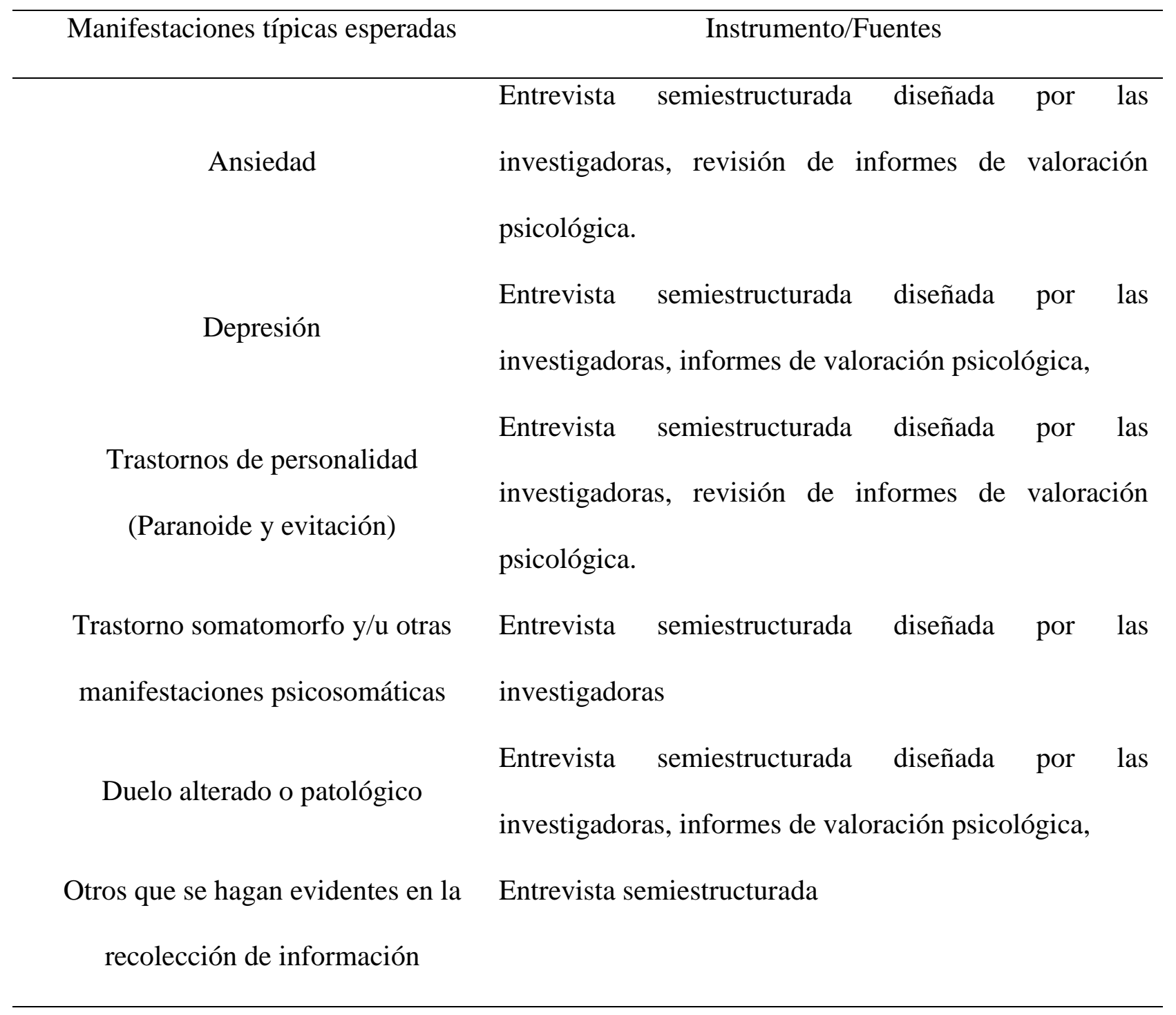

\section{Categoría 2}

Daño psicosocial. Hace referencia a la valoración del sufrimiento humano, destrucción de proyectos de vida, que no solo tiene repercusión individual en la persona victimizada, sino que constituye una afectación clara en su capacidad de establecer relaciones satisfactorias con estructuras sociales más amplias (Rebolledo y Rondón, 2010). 
Tabla 4

Categoría 2. Daño psicosocial

Manifestaciones típicas esperadas Instrumentos

\section{Disfunción familiar}

Alteración de las relaciones sociales

Rechazo social-estigmatización

Grupo focal, revisión de informes de

Cercanía - proximidad- de los victimarios valoración psicológica e historias de

Percepción de inseguridad o miedo al delito vida

Alteración de proyecto de vida

Cambio cultural: Alteración de creencias, desarraigo, cambio hábitos. Disminución de la calidad de vida

\section{Categoría 3}

Percepción de reparación: Según Beristain, (2008) se entiende que:

Para las víctimas, la reparación debería ser la manifestación más tangible de los esfuerzos del Estado por remediar el daño que han sufrido. Pero para ello, [...] se necesita avanzar tanto en los criterios para hacer que sea más positiva y esté más adaptada a las necesidades de las víctimas, como en su cumplimiento efectivo. Para el Estado la reparación es una oportunidad de integrar a las víctimas en la sociedad, pero también de prevenir nuevas violaciones en el futuro. (p.12) 
Tabla 5

Categoría 3. Percepción de reparación

Forma de
reparación * Indicadores


(...continuación) Tabla 5

Categoría 3. Percepción de reparación

a) Verificación de los hechos y conocimiento público de la verdad Grupo

b) restauración de los derechos y actos de desagravio. focal

c) Aplicación de sanciones judiciales o administrativas a los perpetradores

La d) Conmemoraciones y homenajes a las víctimas.

satisfacción $\quad$ e) Búsqueda de los desaparecidos y su identificación

f) Disculpa pública que incluya el reconocimiento de los hechos y la aceptación de responsabilidades

g) asistencia a cursos de capacitación en materia de DD.HH a los perpetradores 
(...continuación) Tabla 5

Categoría 3. Percepción de reparación

a) Control efectivo de las autoridades civiles sobre las fuerzas Grupo armadas y de seguridad;

focal

b) Garantía de que los procedimientos civiles y militares se ajusten a las normas internacionales.

c) Fortalecimiento de la independencia del poder judicial.

d) Protección de los profesionales del derecho, la salud y la asistencia sanitaria, la información, los defensores de los derechos

Las garantías humanos, etc.

de no e) La educación, de modo prioritario y permanente, de todos los repetición sectores de la sociedad respecto de los D.D.H.H. y del D.I.H. y la capacitación en esta materia de los funcionarios, fuerzas armadas y de seguridad.

f) Promoción de mecanismos destinados a prevenir, vigilar y resolver los conflictos sociales.

g) Revisión y reforma de las leyes en instituciones que contribuyan

a las violaciones manifiestas de las normas internacionales de D.D.H.H.

* tomadas de la Ley 975 de 2005. 


\section{Categoría 4}

Revictimización. Esta también se conoce como victimización secundaria y se define como toda acción u omisión que empeore el estado físico y/o psíquico de la víctima cuando busca ayuda y se relaciona con el sistema legal, instancias en las que puede encontrar insensibilidad, incomprensión, nuevas agresiones, que se ponga en tela de juicio, dilaciones o falta de información (Echeburúa, Corral, Amor, 2004 citado en Hernández, 2011) (p.22)

Tabla 6

Categoría 4. Revictimización

\begin{tabular}{|c|c|}
\hline Manifestaciones típicas esperadas & Instrumento \\
\hline \multicolumn{2}{|l|}{ Maltrato y negligencia institucional } \\
\hline \multicolumn{2}{|l|}{ Reiteración del relato } \\
\hline $\begin{array}{l}\text { Información errónea por parte de los } \\
\text { funcionarios. }\end{array}$ & Grupo Focal \\
\hline $\begin{array}{l}\text { Dilación en los procesos judiciales y de } \\
\text { reparación por parte de autoridades }\end{array}$ & \\
\hline
\end{tabular}


Percepción de reparación en familias de víctimas de desaparición forzada $\mid 75$

\section{Método}

\section{Diseño y tipo de investigación}

Esta investigación corresponde a un estudio de tipo mixto, con predominancia cualitativadescriptiva el cual implica una recolección y análisis de datos cuantitativos y cualitativos, así como su integración y discusión conjunta, para realizar inferencias producto de toda la información recabada y lograr un mayor entendimiento del fenómeno bajo estudio, según lo señalan Hernández, Fernández y Baptista, (2010). De acuerdo con estos autores los estudios descriptivos buscan desarrollar una imagen o fiel representación (descripción) del fenómeno estudiado a partir de sus características, busca especificar propiedades, características y rasgos importantes de personas, grupos, comunidades o cualquier otro fenómeno que se analice, lo que concuerda con la pretensión de este proyecto que consistente en analizar la percepción frente a las alternativas de reparación y su relación con el daño psicosocial y el impacto de los procesos judiciales en dos familias víctimas de desaparición forzada de personas.

Esta investigación se desarrolló empleando un diseño de estudio de caso, el cual es definido como "una investigación que mediante los procesos cuantitativo, cualitativo y/o mixto; se analiza profundamente una unidad integral para responder al planteamiento del problema, probar hipótesis y desarrollar teoría" (Hernández Sampieri y Mendoza, 2008 citado en Hernández et al., 2010). Por su parte Yin (2009) citado en Hernández et al., (2010) advierte que un estudio de caso es una indagación empírica que investiga un fenómeno contemporáneo dentro de su contexto en la vida real, en especial cuando los límites entre el fenómeno y el contexto no son claramente evidentes. El estudio de caso no está definido por un método específico, sino por su objeto de análisis. Entre más concreto y único sea éste, y constituya un sistema propio, con mayor razón podemos denominarlo estudio de caso (Hernández et al., 2010). 
Percepción de reparación en familias de víctimas de desaparición forzada | 76

En la presente investigación se contó con la participación de 2 familias (casos) que sobrellevaron la desaparición forzada de Benjamín Duarte y Jeisson Duarte de la Ossa en la ciudad de Barrancabermeja, con un total de 6 integrantes adultos.

La recolección de los datos se realizó mediante diversas técnicas e instrumentos, que más adelante se describen, e incluyó dos etapas donde los resultados de las etapas cuantitativa y cualitativa son integrados durante la interpretación, partiendo de una perspectiva teórica amplia debido a que se hizo una revisión previa de la literatura en materia de desaparición forzada, alternativas de reparación, daños psicológicos y psicosociales típicos en víctimas de delitos de lesa humanidad y los impactos del proceso de judicial incluyendo la subsecuente revictimización a que son sometidas este tipo de víctimas, que constituyó el marco conceptual que orientó está investigación, encontrando que varias investigaciones proponen fórmulas de reparación basadas en lo desarrollado por los instrumentos jurídicos nacionales e internacionales, pero pocos estudios apuntan a documentar lo que esperan los familiares de víctimas de desaparecidos en materia de reparación, siendo este un delito con gran tendencia hacia la impunidad, pues las reglas de la reparación están escritas, pero su aplicación aún se ve obstaculizada debido a las condiciones sociopolíticas del contexto colombiano, por ello se preestablecieron categorías y variables y a lo largo de la recolección de datos emergieron nuevas categorías las cuales fueron confirmadas con las ya establecidas. Finalmente la, información se codificó de manera abierta y nuevamente fue contrastada con la literatura existente.

Para el análisis de los resultados cualitativos se constituyó un paso de estructuración, delimitación, organización y presentación de la información recolectada de una manera lógica y coherente con la intención de condensar dicha información reduciéndola a un número de unidades de análisis limitada, es decir que se codificó la información, a través de un proceso 
mediante el cual se agrupan las narraciones obtenidas en categorías que concentran los conceptos preestablecidos por las investigadoras (Rubin y Rubin, 1995 citado por Fernández, 2006).

Una vez que se encontraron esos conceptos y temas individuales, se relacionaron entre sí para poder elaborar una explicación integrada. En primer lugar, el material se analizó y comparó dentro de cada categoría. Luego, el material se comparó entre las diferentes categorías, buscando los vínculos que puedan existir entre ellas. Posteriormente, se relacionó las categorías obtenidas en el paso anterior, entre sí y con los fundamentos teóricos de la investigación.

En lo referente a la validez de los hallazgos se usaron los criterios enunciados por Porta y Silva (2003):

- Exhaustividad: Agotar el contenido de la totalidad de los datos recogidos.

- Exclusión mutua: Unidad de registro, puesto que, no puede pertenecer a varias categorías.

- Pertinencia: Adaptación del análisis seleccionado y perteneciente al diseño metodológico elegido.

- Productividad: Un conjunto de categorías es productivo si proporciona resultados ricos, tanto en índices de inferencia como en nuevas hipótesis.

Adicionalmente se elaboró la triangulación, entendida esta como el proceso de corroborar la información obtenida mediante la experiencia directa, la observación, el uso de pruebas estandarizadas, entrevistas, el apoyo con otros informantes e investigadores, el empleo de las grabaciones y de otros documentos (Álvarez, 2005)

\section{Participantes}

La muestra con la cual se desarrolló este proyecto de investigación correspondió a seis adultos, familiares de víctimas del delito de desaparición forzada entre los 23 y 50 años de edad, representados y asesorados jurídica y psicológicamente en la ciudad de Barrancabermeja 
(Santander), quienes voluntariamente decidieron participar en el estudio bajo consentimiento informado, de acuerdo con las normas éticas para la investigación con humanos (American Psychological Association, 2002) (anexo A). Por lo tanto, el tipo de muestreo realizado fue no probabilístico, y bajo los siguientes criterios de inclusión a la muestra:

$\checkmark$ Ser mayores de 18 años

$\checkmark$ No presentar discapacidad física o mental que limite su interacción con la sociedad.

$\checkmark$ Ser familiar directo (padres, hermanos, hijos o cónyuges) de una víctima de desaparición forzada.

$\checkmark$ La libre decisión de aceptación en participar de la investigación y de las actividades que se requieran para la misma.

$\checkmark$ Reconocerse a sí mismos en condición de víctimas de desaparición forzada.

$\checkmark$ Participar en la ONG Corporación Nación y estar en la última etapa del proceso de Justicia y Paz.

\section{Técnicas de recolección de información e instrumentos}

La recolección de los datos en esta investigación se llevó cabo a nivel individual y grupal mediante el empleo de varios métodos de recolección de información como el grupo focal (focus groups) a través de una guía de preguntas (anexo B) el diseño de una entrevista semiestructurada individual (anexo $C$ ), las escalas de evitación y paranoia del Examen Internacional de los Trastornos de Personalidad IPDE, módulo DSM-IV (Organización Mundial de la Salud, 1996) (anexo D), Cuestionario de Ansiedad Estado-Rasgo STAI (Spielberger, Gorsuch y Lushene, 2011) (anexo E), el Inventario de Depresión Estado-Rasgo IDER (Spielberger, 2008) (anexo F) y la revisión de informes de las valoraciones psicológicas e historias de vida realizadas a cada uno de los familiares entre los meses de febrero y agosto del año 2011, que fueron facilitados por 
Percepción de reparación en familias de víctimas de desaparición forzada | 79

Corporación Nación-ONG que ha brindado atención psicojurídica a los participantes en Barrancabermeja. Estos instrumentos fueron sometidos a consenso por el equipo investigativo para seleccionar y diseñar aquellos que más se ajustaron al nivel cultural y educativo de las familias participantes. Cabe aclarar que para el cuestionario IPDE, solamente se usaron los ítems que evalúan los trastornos paranoide y de evitación que son los esperados según lo descrito en la Categoría 1.

Los Grupos de Discusión, fueron propuestos a finales de los años ochenta y principios de los noventa, el grupo de discusión permite el diálogo, la conversación y la discusión entre personas desconocidas sobre un tema específico ( Ibáñez, 1994).

Para el trabajo investigativo se hace pertinente la realización del grupo focal que permitió proporcionar un dialogo de saberes entre los distintos tipos de participantes, otorgándoles iguales posibilidades de ser escuchados e incorporados a los saberes técnicos, académicos y populares; valorar la experiencia desde los aportes de los participantes basados en sus vivencias y experiencias, evitándose la preponderancia de expertos y especialistas en el tema y la construcción de los significados que dan los participantes a partir de su realidad dejando claro que se buscó específicamente que fueran personas que no tuvieran dominio de la temática con el fin de enriquecer el discurso.

Para la elaboración de la guía de preguntas del grupo focal presentada en el anexo B, se tuvieron en cuenta las siguientes categorías previamente establecidas: preguntas de la categoría percepción de reparación, preguntas de la categoría revictimización y preguntas de la categoría daño psicosocial.

Los 6 familiares participaron en una única sesión de 3 horas, aclarándoles que el objetivo de la misma era conocer cómo vivieron la desaparición forzada de su familiar y se recordaron los 
conceptos de reparación para que entendieran las preguntas. El registro de la información se obtuvo mediante la grabación en video.

Posteriormente se trascribió la grabación para facilitar el análisis del contenido, se señalaron las narraciones relevantes y estas se agruparon de acuerdo a las categorías prestablecidas. Teniendo en cuenta que algunas narraciones eran similares de un participante a otro, solamente se tuvieron en cuenta las que se relacionan en el apartado de resultados y discusión y que conformaron las unidades de análisis. Este mismo procedimiento se realizó para analizar el contenido de los relatos obtenidos en las entrevistas, las historias de vida y la revisión de informes psicológicos previos.

La entrevista utilizada se basó en los lineamientos propuestos en la ficha técnica elaborada por la Comisión Nacional de Reparación y Reconciliación (CNRR) en Colombia denominada evaluación del daño psicológico de las víctimas de violaciones a los derechos humanos ocurridos en el marco del conflicto armado colombiano, toda vez que el área de reparación y atención a víctimas y la sede regional centro de la CNRR, convocaron en el año 2009 una Mesa de expertos en evaluación y atención de víctimas de delitos ocurridos en el contexto del conflicto armado. Dicha mesa adelanto sesiones de discusión y análisis a partir de las cuales se logró construir una guía de consulta al Comité Nacional de Reparaciones Administrativas y un protocolo (ficha técnica) para la evaluación del daño en casos en donde se han justificado lesiones psicológicas, contando con la validación del instrumento en el territorio colombiano. 


\section{Procedimiento}

En primer lugar El procedimiento de la presente investigación se divide en cuatro fases que son las siguientes fases:

Fase I: Contacto y acercamiento. Fase en la que se establece contacto con los participantes para propiciar un clima de confianza, se explican los propósitos y alcances de la investigación y se obtiene el consentimiento informado, aclarando a los participantes la siguiente información:

1. El objetivo de la investigación.

2. El procedimiento de la investigación, dando a conocer las características generales y la duración de la aplicación de los instrumentos, el grupo focal y entrevistas, advirtiéndoseles que algunas preguntas pueden ser molestas o generar sentimientos de vergüenza, tristeza o rabia.

3. La posibilidad de no aceptar participar en la investigación o de retirarse durante la aplicación de los instrumentos, sin que ello conlleve repercusiones.

4. El anonimato en la contestación de los cuestionarios y el mantenimiento de los cuestionarios aplicados en un lugar reservado.

5. La opción de ofrecer retroalimentación de los resultados obtenidos con cada participante, si éste los solicita o requiere en el proceso judicial adelantado, tras la recolección de los mismos.

6. La independencia de la investigación con respecto a su proceso judicial adelantado.

Una vez obtenido dicho consentimiento informado voluntariamente, se administraron todos los instrumentos de forma colectiva, a excepción de las entrevistas. A su vez, el procedimiento del desarrollo de la investigación tuvo como guía el enfoque de la acción sin daño, que según la Corporación AVRE (2009), es un enfoque ético basado en el antiguo principio hipocrático de la medicina de "no hacer daño", donde se señala que la primera 
Percepción de reparación en familias de víctimas de desaparición forzada $\mid 82$

consideración al optar por un tratamiento es la de evitar el daño. Es por ello, que para las autoras se desprende de allí una obligación moral, reflexión y crítica sobre lo que se va a hacer y sobre "lo actuado" en tanto sus principios, consecuencias e impactos en los participantes.

\section{Consideraciones Éticas}

La presente investigación ha sido diseñada atendiendo a lo planteado por la ley 1090 del 6 septiembre del 2006 por el cual se reglamenta el ejercicio de la profesión de psicología, se dicta el código deontológico y bioético y otras disposiciones rigiendo este estudio bajo los principios universales consagrados como la solidaridad, la confidencialidad, la no maleficencia y la beneficencia, además de los art, 2: puntos 1, 3, 5 y 9, art, 29, 30, 49 y 50 en los que se apoyó este estudio.

Asimismo, la Resolución No. 008430 de octubre 4 de 1993 por la cual se establecen las normas científicas, técnicas y administrativas para la investigación en salud, la presente investigación atiende a lo planteado en el artículo 4, en donde se menciona que la investigación para la salud debe comprender el desarrollo de acciones que contribuyan: a) al conocimiento de los procesos biológicos y sociológicos en los seres humanos. Y al título II en su capítulo I de los aspectos éticos de la investigación en seres humanos, desarrollando nuestra metodología contemplando los aspectos éticos y operativos necesarios para proteger la integridad del participante, sus derechos y bienestar contemplados en el art.5 de la resolución.

Fase II: Selección de los instrumentos y técnicas de recolección de datos. Se hace una revisión de herramientas o técnicas para identificar y valorar el daño psicológico, el daño psicosocial, la percepción de reparación y revictimización durante los procesos judiciales en las dos familias seleccionadas en la ciudad de Barrancabermeja. 
Percepción de reparación en familias de víctimas de desaparición forzada 83

Fase III: Recolección de datos mediante el empleo de los instrumentos cuantitativos y herramientas cualitativas con los participantes: se procede a la aplicación de las herramientas e instrumentos previamente seleccionados y a desarrollar la dinámica de grupo focal, la aplicación de pruebas psicológicas, obtención de historias de vida y entrevistas bajo el consentimiento informado de los participantes en la investigación.

Fase IV: análisis de resultados: Análisis de los resultados obtenidos y desarrollo de la discusión, conclusión según la información obtenida en el proceso de investigación. Como ética de las investigadoras se harán las pericias de cada familia como signo de reciprocidad por su colaboración. 


\section{Resultados y discusión}

A partir de la combinación de las diferentes técnicas de recolección de información e instrumentos empleados, se evaluó el daño psicosocial, el impacto de los procesos judiciales y la percepción de reparación posible en dos familias victimas de desaparición forzada en la ciudad de Barrancabermeja (Santander). Dicha información fue recolectada mediante el empleo de una dinámica de grupo focal y la entrevista individual con cada uno de los participantes. Adicionalmente se adelantó la elaboración de historias de vidas como forma de establecer contacto y empatía con los participantes y su vez para entender su situación antes y después de los hechos de desaparición ocurridos hace más de 10 años, abordando las áreas de ajuste global (Anexo G). Así mismo, se analizó el contenido de los informes de valoración psicológica facilitados por la ONG que atiende a los participantes y que se guardan bajo reserva en medio magnético por ser información confidencial, que sirvió como insumo para analizar las categorías y variables preestablecidas en la presente investigación.

Aunque el énfasis de los resultados se pone en la percepción de la posible reparación, se inició con el análisis de los datos cuantitativos en torno al daño psicológico, seguido del análisis de los hallazgos cualitativos en torno a lo psicosocial, al impacto del proceso judicial para finalmente relacionar los daños con las atribuciones de reparación. 
Percepción de reparación en familias de víctimas de desaparición forzada $\mid 85$

\section{Análisis cuantitativo}

Para determinar si los participantes reportaban síntomas de ansiedad, depresión o un trastorno de personalidad, posiblemente derivados de los hechos victimizantes se emplearon test psicológicos y a continuación se muestran los resultados.

Variable 1 Ansiedad.

Para evaluar esta variable se empleó la Escala de Ansiedad Estado/Rasgo (STAI), diseñada por Spielberger, Gorsuch, y Lushene (1982) con la adaptación española realizada por los autores, con la que se evaluó en los participantes el nivel actual de ansiedad y la predisposición de estos a responder al estrés. El cuestionario STAI consta de 40 ítems y cuenta con escalas separadas de autoevaluación que miden dos conceptos independientes de la ansiedad, como estado (E) y como rasgo (R). La mitad de los ítems pertenecen a la subescala Estado, formada por frases que describen cómo se siente la persona en ese momento. La otra mitad, a la subescala Rasgo, que identifican como se siente la persona habitualmente.

Tabla 7.

Puntaciones por participantes del Cuestionario de Ansiedad Estado - Rasgo (STAI).

\begin{tabular}{lll}
\hline \multirow{2}{*}{ Participante } & \multicolumn{2}{l}{ Puntuaciones en Decatipos } \\
\cline { 2 - 3 } & A-Estado & A-Rasgo \\
\hline JD & 4 & 3 \\
RD & 6 & 6 \\
AD & 7 & 6 \\
SO & 6 & 7 \\
EO & 9 & 9 \\
JJ & 9 & 9 \\
\hline
\end{tabular}


Con base en la tabla anterior se puede inferir que en la aplicación del cuestionario de ansiedad estado - rasgo STAI, dos de los seis familiares obtuvieron una puntuación alta, tomando la media para las puntuaciones en decatipos de 5,50 con una desviación de 2, es decir puntuaciones superiores a 7 .

En general los participantes que puntuaron ansiedad rasgo (AR) positivo pueden ver muchas más situaciones amenazadoras puesto que tienen una relativa estabilidad de propensión ansiosa, es decir, disposiciones que permanecen latentes hasta que son activadas por algunos estímulos de la situación, estas disposiciones comportamentales son adquiridas por residuos de experiencias pasadas, manifestando una tendencia de alta respuesta a un episodio de carácter emocional transitorio ansiedad estado (AE) de tensión e hiperactividad del sistema nervioso autónomo que implique alguna amenaza a la autoestima.

\section{Variable 2 Depresión.}

Para medir la variable depresión se utilizó el instrumento IDER, un inventario muy breve (20 elementos) destinado a evaluar por una parte el grado de afectación (estado) y por otra la frecuencia de ocurrencia (rasgo) que el sujeto muestra en relación con los componentes afectivos de la depresión. Además, los elementos de la prueba están construidos para apreciar tanto la presencia de depresión (distimia) como la ausencia de ésta (eutimia). 
Percepción de reparación en familias de víctimas de desaparición forzada $\mid 87$

Tabla 8.

Puntaciones en percentiles por participantes del Inventario de Depresión Estado - Rasgo (IDER).

\begin{tabular}{|c|c|c|c|c|}
\hline \multirow[t]{2}{*}{ Participante } & \multicolumn{2}{|c|}{ Estado } & \multicolumn{2}{|c|}{ Rasgo } \\
\hline & \%il Eutimia & \%il Distimia & \%il Eutimia & \%il Distimia \\
\hline JD & 60 & 1 & 40 & 1 \\
\hline $\mathrm{RD}$ & 20 & 70 & 1 & 80 \\
\hline $\mathrm{AD}$ & 15 & 70 & 10 & 50 \\
\hline SO & 45 & 75 & 10 & 60 \\
\hline EO & 90 & 45 & 95 & 60 \\
\hline $\mathrm{JJ}$ & 98 & 90 & 85 & 90 \\
\hline
\end{tabular}

Para la interpretación de esta categoría es relevante tener en cuenta que la familia conformada por SO, EO y JJ ha perdido a otro familiar por muerte violenta hace 4 meses a la fecha de la evaluación, además JJ acaba de tener un grave accidente automovilistico. A partir de los datos arrojados en la anterior tabla se puede observar que las puntuaciones altas (por encima de 75) se encuentran en tres personas, probablemente para EO y JJ su estado de ánimo estará relacionado con el hecho victimizante recientemente.

Por lo tanto JJ, presenta en la actualidad un alto grado de afectación (Estado) y frecuencia de ocurrencia (Rasgo) del componente afectivo de la depresión, es decir que, se identifica posiblemente la presencia de episodios o de reacciones depresivas más propensas en ciertas situaciones tales como malestar general, tristeza, soledad, pérdida del entusiasmo, en ocasiones una actitud pesimista, y desesperanza frente al diario vivir, como respuesta al tener que afrontar 
Percepción de reparación en familias de víctimas de desaparición forzada $\mid 88$ su grave accidente automovilístico sumado al hecho victimizante actual más no una reacción netamente relacionada con la desaparición forzada de Jeisson Duarte de la Ossa.

Por otra parte, EO evidencia una alta puntuación en los ítems Eutimia-Estado y EutimiaRasgo, lo que significa que al momento de aplicar el IDER su estado de ánimo pudo presentar bajo nivel de energía, pérdida del entusiasmo, pobre esperanza frente al futuro. De la misma manera se puede observar que EO generalmente mantiene en el tiempo una actitud desinteresada frente a algunas situaciones y sentimientos permanentes de desesperanza probablemente por la ocurrencia de hechos violentos con sus dos hermanos.

Por último, RD y JJ obtuvieron un alto resultado en Distimia-Rasgo de la cual se puede interpretar como la disposición general para responder de manera negativa a las diversas situaciones de la vida donde él interpreta algunos acontecimientos de manera desfavorable más que las demás personas a su alrededor.

De lo anterior, se puede inferir que SO, EO y JJ evidencian una posible disposición a reaccionar mediante un estado de ánimo triste con desesperanza frente a situaciones estresantes, difíciles de afrontar en sus actividades cotidianas reaccionando con mayor malestar que otras personas frente a una misma situación.

\section{Variable 3 Trastornos de personalidad.}

Para determinar si en los participantes la presencia de esta variable se empleó el IPDECuestionario de screening del módulo CIE-10: Examen internacional de los Trastornos de la Personalidad de Loranger, Sartorius, Andreoli, Berger, Buchheim et al, que consta de un instrumento de screening y la propia entrevista. 
Percepción de reparación en familias de víctimas de desaparición forzada $\mid 89$

Siguiendo la nomenclatura del diagnóstico multiaxial del DSM-IV-TR (American Psychatric Association, 2002), enumeramos los Criterios diagnósticos generales para un Trastorno de la personalidad paranoide y de evitación.

Por lo tanto, los criterios para el diagnóstico de F60.0 Trastorno paranoide de la personalidad (301.0) con base en la entrevista realizada según el examen internacional de los desórdenes de personalidad IPDE módulo DSM-IV con sus respectivas puntuaciones son los siguientes:

Tabla 9.

Puntaciones por participantes de los criterios diagnósticos del trastorno paranoide de la personalidad IPDE

\begin{tabular}{|c|c|}
\hline Participante & Puntuación \\
\hline JD & 1 \\
\hline $\mathrm{RD}$ & 2 \\
\hline $\mathrm{AD}$ & 1 \\
\hline $\mathrm{SO}$ & 3 \\
\hline $\mathrm{EO}$ & 1 \\
\hline $\mathrm{JJ}$ & 2 \\
\hline
\end{tabular}

A partir de la tabla anterior se podría decir que los seis participantes presentan un diagnostico negativo para el trastorno de personalidad paranoide toda vez que según el criterio A, relacionado con la desconfianza y suspicacia general desde el inicio de la edad adulta, de forma que las intenciones de los demás son interpretadas como maliciosas, no aparecen en más de cuatro de los puntos anteriores, asimismo, las características del criterio B no aparecen 
exclusivamente en el transcurso de una esquizofrenia, un trastorno del estado de ánimo con síntomas psicóticos u otro trastorno psicótico y no son debidas a los efectos fisiológicos directos de una enfermedad médica.

Ahora bien los criterios para el diagnóstico de F60.6 Trastorno de la personalidad por evitación (301.82) con base en la entrevista realizada según el examen internacional de los desórdenes de personalidad IPDE módulo DSM-IV son los siguientes con sus respectivas puntuaciones:

Tabla 10.

Puntaciones por participantes de los criterios diagnósticos del trastorno de la personalidad por evitación IPDE

\begin{tabular}{ll}
\hline Participante & Puntuación \\
\hline JD & 2 \\
RD & 3 \\
SO & 0 \\
EO & 2 \\
JJ & 1 \\
\hline
\end{tabular}

Se puede inferir de la anterior tabla que los cinco participantes que obtuvieron más de 3 respuestas señaladas en el cuestionario de evaluación IPDE, pero al realizar la entrevista a profundidad indicaron entre dos o tres criterios del trastorno de evitación, lo que descarta un diagnóstico para este trastorno, puesto que un patrón general de inhibición social, unos sentimientos de inferioridad y una hipersensibilidad a la evaluación negativa, que comienzan al 
principio de la edad adulta y se dan en diversos contextos, tendrían que sumar cuatro (o más) de los ítems que refiere en DSM-IV (2002).

Además es importante anotar que un trastorno de personalidad debe cumplir los siguientes criterios según el DMS-IV (2002):

A. Un patrón permanente de experiencia interna y de comportamiento que se aparta acusadamente de las expectativas de la cultura del sujeto. Este patrón se manifiesta en dos (o más) de las áreas siguientes:

1. Cognición (p. ej., formas de percibir e interpretarse a uno mismo, a los demás y a los acontecimientos)

2. Afectividad (p. ej., la gama, intensidad, labilidad y adecuación de la respuesta emocional)

\section{Actividad interpersonal}

4. Control de los impulsos

B. Este patrón persistente es inflexible y se extiende a una amplia gama de situaciones personales y sociales.

C. Este patrón persistente provoca malestar clínicamente significativo o deterioro social, 1 aboral o de otras áreas importantes de la actividad del individuo.

D. El patrón es estable y de larga duración, y su inicio se remonta al menos a la adolescencia o al principio de la edad adulta.

E. El patrón persistente no es atribuible a una manifestación o a una consecuencia de otro trastorno mental. 
Percepción de reparación en familias de víctimas de desaparición forzada | 92

F. El patrón persistente no es debido a los efectos fisiológicos directos de una sustancia (p. ej., una droga, un medicamento) ni a una enfermedad médica (p. ej., traumatismo craneal).

Por tal motivo, se concluye que los participantes no cumplen los criterios para tener un trastorno de personalidad. Posiblemente los participantes de la investigación presentan episodios de evitación específicos derivados de algunas situaciones donde han visto amenazada su vida, lo que genera reacciones acompañadas con ideas paranoides tales como reticencia a confiar en los demás por miedo a que la información que compartan vaya a ser utilizada en su contra, percibir ataques o amenazas en comentarios o conductas contra a su persona y desconfiar de las demás personas. También se identifica que probablemente la respuesta de preferir trabajar solo, no relacionarse con la gente o no participar en actividades sociales que podrían resultarles comprometedoras, responde a la pérdida de confianza derivada de los hechos de desaparición forzada y las amenazas que tuvieron vivir esto familiares más que a un trastorno de personalidad por evitación ya que no se evidencia en ellos un temor, preocupación constante por ser criticado o ridiculizado.

Del análisis de las puntuaciones obtenidas en los instrumentos empleados para determinar la presencia o no de las variables establecidas, se concluye que existen manifestaciones de ansiedad, tristeza, comportamientos evitativos y de alerta permanente, aunque no se confirma un trastorno mental en los participantes de esta investigación en el momento de la evaluación. Dichas manifestaciones son esperables en personas que han sido víctimas de algún evento violento, como lo es en este caso la desaparición forzada de un miembro de la familia.

Por otra parte, las secuelas a nivel psicológico encontradas en los familiares participantes tienden a mantenerse por diversas razones, tales como desconocer el paradero de Benjamín 
Duarte y Jeisson Duarte de la Ossa, la ocurrencia de situaciones revictimizantes relacionadas con la larga espera para obtener una reparación palpable producto del proceso judicial emprendido y la muerte reciente de otro familiar en circunstancias que aún no se han esclarecido.

Lo anterior concuerda con lo encontrado en otras investigaciones sobre el tema, en las cuales se ha documentado que situaciones como la desaparición forzada u homicidio de un ser querido, no siempre dejan evidencias de maltrato físico en las familias, pero si generan secuelas psicosomáticas, emocionales, psicológicas y psicosociales, tales como, tristeza, desasosiego, duelo alterado, abuso de sustancias psicoactivas, deterioro de las relaciones familiares y sociales, perdidas económicas, estigmatización, frustración tras la impunidad de los hechos, terror extremo (angustia) manifestado en el temor a hablar y denunciar, al llegar al lugar de las exhumaciones o temor a que les pueda ocurrir lo mismo que a sus seres queridos (Quintero, 2010; Gómez, 2009; Aguilera, 2006).

Vale la pena aclarar que los resultados individuales por si solos no dan cuenta de la magnitud de los daños, sin embargo, son un punto de partida que se confirma al observar los daños psicosociales y que juegan un papel fundamental a la hora de coadyuvar a que las victimas definan lo que esperan en materia de reparación. 
Percepción de reparación en familias de víctimas de desaparición forzada | 94

\section{Análisis Cualitativo}

Tras la realización del grupo focal, las entrevistas, la revisión de informes de valoración psicológica e historias de vida de los participantes, se transcribieron las narraciones para proceder a realizar el análisis cualitativo, seleccionando los relatos (unidades de análisis) de los participantes que evidencian manifestaciones de algún tipo de daño psicológico, daño psicosocial, la percepción y expectativas de reparación que tienen los familiares participantes y situaciones de revictimización vividas en los procesos judiciales adelantados tras las desaparición de los seres queridos, para después categorizarlos manualmente. A continuación se presentan los resultados del análisis cualitativo de este trabajo investigativo, organizados por categorías.

\section{Categoría 1 Daño psicológico.}

Ansiedad: desde el momento en que ocurren los hechos de la desaparición forzada de Jeisson Duarte de la Ossa y Benjamín Duarte hasta la actualidad, persisten en los familiares manifestaciones de daño psicológico, es este caso secuelas emocionales que coinciden con síntomas de ansiedad que son esperables en víctimas de desaparición forzada.

El relato de RD muestra su reacción en el momento en que se enteró de la desaparición de su padre Benjamín Duarte: “cuando me contaron lo que pasó, me sentí angustiado, desesperado no sabía qué hacer para dónde coger, es muy duro no saber nada de su ser querido”. Así mismo, la señora SO madre de Jeisson Duarte de la Ossa, comenta lo que continúa sintiendo por no saber nada del paradero de su hijo: "siento incertidumbre, oprimida, me siento desprotegida, miedo frecuente". Por su parte EPO, uno de los hermanos de Jeisson Duarte de la Ossa también describe lo que experimenta actualmente como consecuencia de la desaparición de su familiar: "tengo mucho miedo a morir, cuando hablo de esas cosas tengo sensación de ahogo". 
Percepción de reparación en familias de víctimas de desaparición forzada $\mid 95$

Relacionando lo encontrado en los hallazgos cuantitativos con los cualitativos, como es propio de un estudio mixto, las autoras ratifican la presencia de rasgos de ansiedad que no responden a la presencia de un trastorno como tal. Desde esta perspectiva, bien puede ser que un trastorno psíquico constituya un modo anormal de reaccionar frente a una situación normal; pero bien puede ocurrir también que se trate de una reacción normal frente a una situación anormal (Martín-Baró, 1990). En aras a esto, la reparación debería comprender un tratamiento integral como un acompañamiento psicosocial adecuado a violencia sociopolítica y no como un abordaje clínico y farmacológico.

En tal sentido, autores como Aguilera (2006) y Cabanillas (2005) coinciden en afirmar que tras experimentar la pérdida abrupta de un ser querido aparecen reacciones normales de tristeza, ansiedad, desasosiego, y que la angustia y ansiedad vividas tras la búsqueda no necesariamente conforman patologías, es decir que son reacciones normales ante este tipo de eventos traumáticos, tal como ha venido sucediendo con los familiares participantes de esta investigación.

Tristeza: otra de las secuelas a nivel emocional evidenciadas en el relato de los familiares víctimas de desaparición forzada, son las que tienen que ver con manifestaciones de tristeza, pues de acuerdo a los resultados del IDER, se pudo determinar que actualmente no existe un trastorno de depresión, no obstante, se evidencia en algunos participantes pérdida de interés por las actividades que antes resultaban agradables, llanto, aislamiento, entre otras reacciones que se aproximan a los síntomas característicos de un cuadro depresivo.

La señora SO, madre de uno de los familiares desaparecidos llora constantemente, especialmente cuando de alguna manera recuerda los hechos victimizantes ella manifiesta: "lloraba mucho de día y de noche”. La señora SO también expresa no disfrutar de sus 
Percepción de reparación en familias de víctimas de desaparición forzada | 96 actividades cotidianas como lo hacía antes y reporta distanciamiento de los demás: "me siento triste, desanimada, no disfruto las cosas como antes, aún lloro por mis hijos, no duermo muy bien, busco estar sola”. El señor RD expresa: “No disfruto las cosas como antes”. Por su parte, el señor JD, relata que tras el hecho de desaparición forzada de su padre presenta dificultades para expresar lo que siente, lo que le genera en él sentimientos de tristeza: "es una experiencia para adultos, porque uno no sabe cómo vivirlo y expresarlo, es cómo si le atropellarán todo el mundo a uno... a veces solo me siento triste”. Por su parte, cuando AD habla de su padre sus ojos se tornan llorosos: "siento que me han segado, era mi consejero y eso me da tristeza, me sentía seguro con sus consejos de padre (ojos llorosos)"

Tal como se evidencia en otros casos latinoamericanos documentados, como el de Rosendo Radilla, una víctima mexicana de desaparición forzada (Antillón, 2008) o el trabajo realizado en Guatemala por Gómez (2009), en donde se brindan herramientas para realizar peritajes psicológicos en situaciones de daño a la integridad mental producto de delitos de lesa humanidad, las manifestaciones de tristeza son un rasgo común en los familiares de víctimas de la violencia sociopolítica, constituyéndose este como uno de los daños psicológicos que perduran inclusive durante décadas.

Al complementar esta información con lo analizado en los resultados cuantitativos se ratifica la postura en que se encuentran daños que no necesariamente son de carácter patológico, lo que sugiere una atención oportuna que tenga el carácter de prevención secundaria, es decir que logre amortiguar la prolongación de la tristeza, no obstante el hecho de desconocer el paradero de los familiares y la impunidad que implica el delito de desaparición forzada, permiten suponer que la tristeza acompañará a largo plazo a estas familias. 
Percepción de reparación en familias de víctimas de desaparición forzada | 97

Ideas paranoides y de evitación: en el análisis cuantitativo se descartó algún trastorno de personalidad de tipo paranoide o de evitación, sin embargo de la sesión de grupo focal y de la revisión de informes de valoración psicológica se recopilaron algunos relatos que indican que los participantes se encuentran en alerta permanente $\mathrm{y}$ mantienen ideas en torno a peligros inminentes derivadas de situaciones reales y de evitación como se ejemplifica a continuación:

"Siempre estoy alerta después de todo lo que pasó, me paro a ver quién está por ahí como raro parqueado" (JD)

"Tengo que esforzarme mucho para evitar actividades, lugares y personas que me recuerdan lo que paso” (JD)

“A veces siento distanciamiento frente a los demás, poco interés en participar en actividades" (SO)

“Estoy siempre atenta a los comentarios y a las personas que están a mi alrededor, por mi seguridad" (SO)

"Me sobresalto alarmándome más fácilmente que otras personas después de los hechos" (EO)

Después de los hechos de la desaparición forzada de Benjamín Duarte y Jeisson Duarte de la Ossa, los familiares han adoptado comportamientos de evitación de lugares y actividades, aislamiento social y desconfianza hacia los demás, que no necesariamente responden a un trastorno de personalidad paranoide o de evitación, pero que a raíz de las situaciones en donde se ha visto comprometida la vida e integridad de estas personas, es esperable que se generen ciertos comportamientos evitativos dentro de un contexto de vulnerabilidad recurrente dentro del marco del conflicto armado en la región del magdalena medio. 
Percepción de reparación en familias de víctimas de desaparición forzada | 98

No obstante, los rasgos o trastornos de personalidad pueden tener comorbilidad con otros trastornos. En este sentido Palacios y Heinze (2002) reportan lo siguiente:

El Trastorno por Estrés Postraumático se asocia con frecuencia a otros trastornos psiquiátricos comórbidos, como el trastorno depresivo mayor, trastorno de angustia, fobia social, trastorno de ansiedad generalizada, trastorno por uso de sustancias, principalmente alcohol, trastorno de personalidad (p.ej., limítrofe, evitativo, antisocial, etc.) y los trastornos disociativos.

Por lo anterior se concluye que las manifestaciones de ideas paranoides o evitativas de los familiares participantes son comportamientos funcionales que refuerzan estrategias de autoprotección frente a un entorno represivo los cuales constituyen un aprendizaje para el afrontamiento de riesgos posibles y reales, con el fin de recomponer sus proyectos de vida. Probablemente en un contexto social seguro estas víctimas lograrían disminuir tales conductas hipervigilantes, lo cual se lograría en un contexto de garantías de no repetición, situación improbable con la realidad colombiana actual, por lo tanto esta reparación además de satisfacer a estas víctimas en particular, favorecería a la sociedad en general.

Según describe Gómez (2009), los acontecimientos traumáticos desencadenan respuestas propias de un Trastorno por Estrés Postraumático caracterizado por: a) respuestas de reexperimentación del acontecimiento traumático; b) anestesia afectiva y evitación de cualquier tipo de personas, lugares, pensamientos que le recuerden el acontecimiento traumático; y c) respuestas de aumento de activación o hipervigilancia. Esta sintomatología concuerda con lo experimentado por los familiares tras el evento traumático de la desaparición de Benjamín Duarte y Jeisson Duarte de la Ossa y coexiste con otro tipo de daños psicológicos encontrados en 
los familiares participantes que se han descrito en la presente investigación y que al momento de llevarla a cabo aun en los participantes.

Manifestaciones psicosomáticas: en la actualidad no se evidencian manifestaciones psicosomáticas fuertes en los familiares participantes, sin embargo ellos recuerdan cambios en sus hábitos de sueño, alimentación y algunos padecimientos físicos como dolores de cabeza derivados de su estado emocional durante los primeros años que transcurrieron tras la desaparición de sus seres queridos tal como se muestra a continuación:

“mi mamá dejo de comer, lloraba mucho de día y de noche, se enfermó, bajo de peso" (SO)

“los primeros días no podía dormir y menos comer" (SO)

“mantenía con dolor de cabeza y el ritmo cardiaco acelerado” JD

“cuando hablo de los hechos me da dolor de cabeza y puntadas en el pecho, sensación de ahogo, tuve miedo de volverme loca los primeros años” SO

"Los primeros años después de los hechos tenía dificultad para dormir y estar concentrado” JD

Los sucesos traumáticos dejan huellas a modo de cicatrices psicológicas y hacen a las personas más vulnerables a los trastornos mentales y a las enfermedades psicosomáticas (Echeburúa, Corral y Amor, 2004). A través del cuerpo, la persona expresa su malestar psicológico, y sobre todo en situaciones de estrés extremo y/o en situaciones de tensión psicológica permanente y la exposición a graves riesgos para la salud (Gómez, 2009). Las manifestaciones psicosomáticas son un rasgo esperable en víctimas de delitos violentos. Dolores de cabeza, pérdida del apetito, sensación de ahogamiento, aumento del ritmo cardiaco y dificultades para dormir se han evidenciado en los familiares participantes. 
Con este hallazgo se podría suponer que las victimas requieren atención médica de emergencia y no esperar hasta que se restablezcan por si mismas o hasta que un fallo judicial así lo ordene. Siguiendo esta línea de pensamiento, se anticipa que las víctimas participantes pierdan interés en una rehabilitación a manera reparación.

Proceso de duelo: El duelo es un proceso normal ante la pérdida de un ser querido, que genera dolor y sufrimiento y que en casos como la desaparición forzada, en donde los familiares viven con la incertidumbre constante por no haber tenido la oportunidad de encontrar el cuerpo del familiar ni realizar el ritual de entierro, se generan dificultades para cerrar el duelo y se prolonga el dolor (Antillón, 2008). En los familiares de Benjamín Duarte y Jeisson Duarte de la Ossa el duelo esta inconcluso, con ilusiones de que el familiar este aún vivo y con la impotencia de no poder dar con su paradero. Esto a su vez ha dificultado el esclarecimiento de los hechos y la búsqueda de la verdad. Sin embargo, se logra determinar que estas familias han vivido el duelo de una forma esperable en este tipo de situaciones, que no necesariamente sugiere un duelo patológico en todos los participantes, como lo demuestran las siguientes narraciones:

"yo siento que mi hijo está vivo, que él está en tierra y no en el agua como dicen ellos (paramilitares), no acepto que él está muerto y menos sin ver su cadáver guardo la esperanza y no acepto que él esté muerto así los paras lo hayan confesado"(SO)

“Para mí fue un proceso muy duro y difícil de superar debido a que todos los días debía llegar a la misma casa, lugar, habitación y ver los recuerdo de mi padre allí sin ninguna noticia, todos mis hermanos afrontaron el dolor en silencio y reserva, cada uno a su manera por aquello de que los hombres no lloran”. (RD) 
"con mis hermanos no hablamos de lo que sentimos o como nos sentimos, pero la reacción de nosotros después de los hechos fue de desorden, solo nos encontrábamos para tomar" JD

"La verdad a mí me gustaría que estuviese al lado de nosotros" $R D$

“yo no lloré pero pensaba mucho en él, por qué, quién lo hizo" $R D$

“cuando hay fechas especiales, siento mucha melancolía y tristeza porque no se nada de mi padre" RD

"Después de los hechos perdí el interés por celebrar cualquier fecha especial, no me gusta que celebren mis cumpleaños" EO

"yo nunca hablo de eso y menos de lo que siento, pero es duro, me siento mal porque era con quien jugaba, con quien más pasaba tiempo, lo recuerdo mucho" EO

"Mi abuela se enfermó y no volvió a sonreír como lo hacía cada vez que la íbamos a visitar, por el contrario cada vez que íbamos ella me decía: "llego mi hijo y lloraba mucho", pues yo me parezco mucho a mi padre. La abuela se deprime lloraba mucho, no comía y perdió la motivación para seguir viviendo, por eso ella muere de "pena moral" (JD)

Como lo demuestran los anteriores relatos, los familiares de Benjamín Duarte y Jeisson Duarte de la Ossa han pasado por un proceso de duelo en medio de la violencia política, en donde no se ha podido constatar la muerte del ser querido, lo que obstaculiza la elaboración del duelo, logrando alterarse y prolongarse. Autores como Prigerson (1995) citado en Antillón (2008) sugieren que los síntomas de duelo complicado se caracterizan por la búsqueda del pariente desaparecido, desear fuertemente la presencia del otro, rumiación y preocupaciones constantes en relación al desaparecido, incapacidad de creer verdaderamente en la muerte del familiar, sentirse impactado o con estupor por el acontecimiento traumático, rechazo de aceptar 
la muerte, que para el caso de los familiares de Benjamín Duarte y Jeisson Duarte de la Ossa es una constante por el hecho de no haber encontrado los restos de sus familiares y llanto frecuente. Los anteriores síntomas están presentes en los familiares participantes, en algunos con mayor intensidad que en otros.

De lo anterior se colige que son dos las necesidades de estas víctimas, la primera el conocimiento de la verdad y la segunda la búsqueda, identificación y entrega de los cuerpos, idealmente la reparación debería apuntar a ambas, como se aprecia en las sentencias proferidas por la Corte Interamericana de Derechos Humanos, sin embargo el fallo judicial no garantiza que las dos necesidades sean satisfechas, por lo cual las víctimas deberán ajustarse a la realidad de los avances de la investigación judicial.

Sentimientos de culpa: Conjuntamente, por ser la desaparición un fenómeno sin lógica posible, generalmente se desarrollan sentimientos de culpabilidad entre aquellos con mayor identificación afectiva hacia la víctima, que hacen aún más difícil soportar el ciclo nunca cerrado de dolor. El fracaso en la búsqueda y la falta de respuesta de las autoridades confrontan a los familiares con la pregunta: “¿estará vivo o muerto?”. La aceptación de la desaparición se asocia con fantasías de tortura y otros vejámenes (Antillón, 2008). Esto facilita la aparición de culpa y el sentimiento de pérdida de los seres más cercanos. Hay mucha angustia y aparición de cuadros de depresión que se manifiestan en periodos de mayor frustración. Los relatos recopilados permiten identificar sentimientos de culpa en los familiares participantes:

"lo hubiera sacado a tiempo como lo hice la primera vez ó le hubiera puesto más pantalones y manos firme. Debería haber previsto cual iba a ser el curso de los hechos y haber encontrado la manera de cambiarlo... No hice todo lo que podría haber hecho para evitar lo que pasó” (SO) 
"Yo no puedo dormir tranquila... para ese momento hubiera sido más dura al corregirlo por eso tengo la culpa, pienso que estoy siendo castigada por algo” (SO)

“me siento culpable en bastantes ocasiones por lo que paso, si hubiera estado en Yondó, yo hubiera estado con él” JD

“me sentí culpable de lo que paso y empecé a preguntarme qué fue lo que paso, en qué momento una vida se va de un momento a otro" EO

Estos sentimientos de culpa generalmente son irracionales y la reparación debería apuntar a mitigarlos con un tratamiento. Aunque existen diferencias individuales, se denota que en algunos familiares esta culpa persiste y no remite espontáneamente como sucedió con los síntomas somáticos.

Sentimientos de ira: La falta de justicia por parte de las autoridades, desencadena en los familiares expresiones de ira, rabia, frustración o deseos de tomar justicia por sus propias manos. A su vez, el estado de ánimo irritable se vuelve habitual en estas personas. Esta rabia se extiende hacia cualquier grupo militarizado, sea que se trate de fuerzas armadas del estado o ilegales. No obstante, estas son ideas y sentimientos que han mantenido los familiares, sin que ellos hayan gestado algún plan de venganza, por el contrario manifiestan abiertamente su rechazo ante cualquier vía armada para solucionar los conflictos. Para ilustrar los sentimientos de ira se presentan las siguientes narraciones:

"parecía que todo el mundo se acababa y no deseaba tampoco seguir adelante con mi proyecto de vida, me llene de odio, rabia y tristeza, con ganas de vengarme y sacarme el odio con la persona que me arrebato la vida de mi hermano” (EP) 
Percepción de reparación en familias de víctimas de desaparición forzada | 104

"no puedo ocultar que he vivido durante todos estos años con un profundo odio hacia los responsables de lo ocurrido, aún hoy en día, odio y guardo mucha rabia y resentimiento a los autores del hecho" (EP)

"Pasaron 5 años para resignarme a que mi papá está muerto, y eso se dio solo cuando "Pocalucha” hablo, sé que está muerto, pero aún no me resigno del todo y menos sin saber el lugar exacto de donde lo lanzaron" (JD)

"El odio hacia quienes tuvieron que ver, la sed de venganza, acaban con cualquier pensamiento bueno y con el interés propio” JD

“Al principio sentí mucha rabia por la injusticia, no tome venganza por la crianza que tuve" $A D$

“mantuve muchos años irritable a veces con explosiones de ira por nada” JD

“tengo explosiones de ira con frecuencia, a veces estoy irritado” EO

"después de lo que paso sentí mucha rabia hacia cualquier grupo armado tanto que hasta la fuerza pública la detesto y hacia cualquier persona que porte armas, no es mala idea acabar con ellos" EO

Los sentimientos de ira ante la falta de sanción de los perpetradores de la desaparición forzada de Benjamín Duarte y Jeisson Duarte de la Ossa coinciden con lo encontrado por Gómez (2009), en donde situaciones similares acompañadas de impunidad dejan impactos sobre la salud mental derivadas en reacciones de cólera, rabia, enojo o tristeza.

Los sentimientos de ira evidenciados en los familiares se derivan en dos sentidos, uno por los hechos victimizantes y dos por la impunidad, solo a esto último podría favorecer la reparación. 
En este sentido, el solo hecho de obtener un fallo puede producir un alivio en la salud mental de las víctimas, es decir, de obtenerse una oportuna solución de la justicia se puede obtener una recuperación de la salud física y mental de las víctimas, potenciando las intervenciones a nivel psicoterapéutico (Cañas y Tapias, 2012).

No obstante, puede ocurrir lo contrario, que tras un tiempo prolongado el proceso judicial termine y las familias presenten dificultades para reconstruir sus vidas, pues su identidad y sentido de vida giraban en torno a la búsqueda de justicia aferrándose al recuerdo de su familiar. Es en la culminación del proceso que las familias toman mayor consciencia del daño que les ha hecho el sistema de justicia. Además en la mayoría de los casos, los tiempos del proceso legal son distintos al ritmo emocional de asimilación de los hechos traumáticos, en donde se obtiene un sentencia o acuerdo, sin que se haya logrado el cierre psicológico pues este sigue abierto hasta el cumplimiento efectivo de la reparación (Beristain, 2010), lo que en la práctica, para casos de desaparición forzada, es poco frecuente.

\section{Categoría 2 Daño psicosocial}

El impacto de la desaparición forzada de Benjamín Duarte y Jeisson Duarte de la Ossa ha ocasionado en sus familiares secuelas a nivel psicosocial, que concuerdan con lo descrito por Gómez (2009), en el sentido en que se han alterado las relaciones interpersonales, se evidencia un deterioro las relaciones de confianza, se inhibe la comunicación, los familiares han tenido aislamiento social, estigmatización y señalamientos, han convivido en el mismo lugar con los victimarios, existe un grado de inseguridad, miedo y tensión permanente, han buscado apoyo en servicios de salud, ONG`s, han presentado cambios en la estructura comunitaria y cultural, modificación de roles y dinámica familiar, desplazamiento forzado entre otras consecuencias. A 
Percepción de reparación en familias de víctimas de desaparición forzada $\mid 106$

continuación se extraen algunos relatos que evidencian el impacto psicosocial en los participantes tras la desaparición de sus seres queridos:

Alteración de las relaciones familiares: Los hechos de desaparición forzada han propiciado en estos familiares, múltiples impactos a nivel familiar, evidenciado en sobreprotección de parte de la madre hacia los demás hijos, cambio en las costumbres y actividades familiares, silencio o evitación para hablar de lo ocurrido. También se vieron cambios en los roles familiares. Esta alteración en las relaciones familiares está muy relacionada con otras afectaciones como el desplazamiento forzado sufrido y la ruptura de un proyecto de vida.

"No hice todo... por eso ahora como sea defiendo a mis hijos de lo que sea, al menor vivo encima de él para que no se me vaya a mal encaminar, trato de estar muy pendiente de ellos"(SO)

"La integración y unión familiar cambió radicalmente, los primeros días fueron muy duros debido a que era el mayor y no sabía qué hacer en ese momento” (RD)

"La relación con mis tíos se rompió por completo y los primeros años nos alejamos de mi tía, el trato no era igual que antes. Luego con el tiempo mi tía al ver nuestras necesidades, cambio un poco apoyándonos en los estudios". (JD)

“...empecé a consumir de bebidas alcohólicas y a llegar borracho a la casa, peleaba mucho con mi padrastro, por eso me fui de la casa a vivir en una habitación en arriendo. (JD)

"La integración y unión familiar que se tenía con mis tíos y tías se rompió totalmente, no se volvieron hacer asados ni comidas familiares" (FD)

“...todo se derrumbó, para mí no ha sido fácil, la vida ha sido muy dura...” RD 
“Todo fue como cuando se deja caer un racimo de uvas, todas se dañan, si ve...ya nada volvió a ser por lo menos igual en mi familia” JD

“como familia los domingos nos reuníamos para hacer asados en la casa, para compartir, después de la muerte de mi padre todo se acabó” AD

“Después de los hechos la comunicación con mi madre disminuyó, porque mi tía no me dejaba hablar mucho” EO

"se truncó la relación con mis hermanos porque se alejaron de mi” SO

"yo me pongo a pensar que mis hijos no van a tener los consejos de un abuelo, yo no se ni que decirle a veces donde esta cuando me preguntan por él”

La desaparición forzada tiene repercusiones sobre los familiares, generando enfriamiento de las relaciones familiares, disminución en la comunicación, sentimientos de sobreprotección, cambio en las costumbres familiares y perdida de interés por actividades familiares que antes resultaban agradables (asados familiares), lo cual es esperable y comprensible. La pérdida de interés por el mundo y las relaciones significativas, el silencio como mecanismo de evitación de conductas referidas a la posibilidad de muerte son descritas por Antillón (2008) en un caso documentado de desaparición forzada en México y concuerdan con los impactos encontrados en los familiares de Benjamín Duarte y Jeisson Duarte de la Ossa.

Alteración de las relaciones sociales: tras la desaparición de un ser querido, surge desconfianza hacia las demás personas y como consecuencia la familia decide aislarse de las demás esferas de la sociedad o se limitan a mantener contacto con ellas solo para lo necesario. Así mismo, algunos familiares participantes adoptan conductas negativas, como agresividad, alcoholismo o pandillismo.

"mi mamá dejo de trabajar y salir a la calle durante muchos meses" (SO) 
Percepción de reparación en familias de víctimas de desaparición forzada | 108

"Al enterarme de la desaparición de mi hermano, mi comportamiento empieza a cambiar, me hice amigo de personas raras y empiezo a tomar mucho alcohol" (EP)

“Antes de los hechos tenía muchos amigos, salía a bailar, me gustaba disfrutar de paseos familiares y de integración social, además tenía una estabilidad laboral” (SO)

"tomo una conducta de agresividad y venganza pero al mismo tiempo me alejo de las personas, amigos y de las actividades de recreación” (EP)

“no tengo la misma relación que tenía antes, no confío en la gente, se acabó mi alegría" $(\mathrm{SO})$

"En el colegio hace nuevas amistades, con las cuales comienza a robar pequeñas cosas, debido a esas conductas ilícitas es llevado a la correccional de menores, luego de 2 meses queda libre porque estaba estudiando y no tenía antecedentes"(JD)

"Hubo cambios con los amigos ya que tome una actitud más responsable y adulta, empecé a trabajar y hacer actividades que para muchos adolescentes no son sus responsabilidades, deje de hablarme con mis amigos y encontré nuevas amistades con las cuales empecé a robar, beber alcohol" JD

“Cuando era niño mis amigos eran de la misma edad mía, pero después los amigos los prefería más grandes porque quería asimilar las cosas como un adulto y comportarme como un adulto, esto al final me permitió ser más responsable.”JD

“imposible olvidar todo, mis amigos me lo recordaban y a veces me preguntan por él, prefiero alejarme un poco para que no me pregunten” $R D$

“yo jugaba mucho con mis amigos cuando iba al pueblo después de la desaparición de mi padre, no volví a bajar al pueblo, deje de jugar y me mude para barranca" AD 
“me volvi frio ante los problemas de los demás, me aísle de todos, quería estar solo con mis sentimientos" EO

“yo antes tenía muchos amigos, ahora creo no hay amigos uno tiene conocidos” EO

“el temor de hablar de los hechos causo desconfianza en todas las personas” JD

Luego de los hechos de la desaparición forzada, algunos familiares asumieron una postura apática y de desconfianza frente a los demás, restringiendo cada vez más el contacto con amigos y vecinos, y otros entablaron nuevas amistades que en su momento propiciaron la comisión de delitos y demás comportamientos destructivos, como el consumo de sustancias psicoactivas. Aunado a lo anterior, el temor a una nueva perdida incrementa la desconfianza hacia las demás estructuras sociales.

En otros casos latinoamericanos documentados sobre delitos de lesa humanidad, las relaciones de confianza se han visto notoriamente deterioradas, al igual que ha sucedido con las de los familiares participante, como lo refiere Gómez (2009): al no investigar y sancionar a los verdaderos culpables se buscan culpables que resultan siendo personas cercanas, como familiares vecinos o amigos.

Rechazo social: A nivel social, los familiares viven el drama del estigma y marginación, la denigración de las víctimas por parte de las autoridades, la pérdida de estatus y valoración social, los señalamientos y el rechazo social. Al mismo tiempo se conforman nuevas redes de apoyo en donde los familiares y organismos de derechos humanos tienen un papel fundamental.

“algunos de mis hermanos y familiares me tenían miedo, ellos pensaban que si yo estaba cerca de ellos les podía pasar lo mismo” (SO) 
"La relación social con los vecinos, amigos y grupos que reporta Sonia durante los primeros años fueron muy frustrantes, debido a que tuvo que afrontar simultáneamente los señalamientos y rechazo de la mayoría de personas en el municipio de Yondó” (SO)

"ahora hablo con muy pocas personas, tengo menos amigos, muy poco salgo a la calle, se fueron acabando las amistades y la desconfianza de todo aquel que se me acercaba."(EO) ...perdió la confianza en las personas, hubo señalamientos fuertes por parte de los vecinos y de algunas personas que conocían a sus padres. Además aún en él permanece el temor de hablar de los hechos con las demás personas. (JD)

"Hubo estigma social, por lo que la familia trato de mantener el hecho en reserva" (JD)

Luego de la denuncia de los hechos de la desaparición forzada de Benjamín Duarte y Jeisson Duarte de la Ossa, sus familiares han sido sometidos a señalamientos por parte de su círculo social, generando desconfianza hacia los demás, incluso hacia vecinos, familiares y amigos. Debido a este rechazo social los familiares viven un temor constante y evitan hablar de lo sucedido por miedo a nuevos señalamientos o amenazas.

Lo anterior genera una modificación de las relaciones sociales derivando bien sea en aislamiento o en dependencia emocional, tal como lo ha descrito Esbec (2000), citado en Echeburúa, Corral y Amor (2002). Por su parte Gómez (2009) analiza el clima emocional de las victimas sobrevivientes aduciendo impactos en las relaciones interpersonales, tales como respuestas de apoyo o rechazo social, existencia o no de acusaciones entre personas, la estigmatización o etiquetamiento de las víctimas y sobrevivientes, lo que concuerda con lo experimentado por los participantes de esta investigación.

En este sentido, el reconocimiento público de la responsabilidad por parte de los perpetradores y la publicación en prensa para dignificar el nombre de las victimas contribuiría a 
minimizar el estigma generado sobre los familiares víctimas. Se esperaría que las victimas pidieran la reparación en este sentido, para así restaurar el vínculo social.

Alteración del proyecto de vida: El proyecto de vida es entendido como el conjunto de expectativas, metas, deseos y visión de uno mismo en el futuro; en un ámbito familiar, social, cultural, económico, educativo, personal, laboral y afectivo (Gómez, 2009). Puede observarse que tanto a nivel individual como familiar, muchos de los planes que tenían los familiares antes de los hechos se vieron truncados o aplazados, teniendo como repercusión la pérdida de oportunidades laborales, económicas y de educación.

"no pude continuar mis estudios de soldadura y menos brindarle seguridad educativa a mi hijo menor. El trabajo que tenía en Ecopetrol lo perdí, del cual todos los compañeros de la época quedaron fijos en la empresa” (SO)

"El dinero que tenía ahorrado antes de los hechos, lo gaste en su totalidad porque debido a mi crisis nerviosa y mi tristeza vivía de un lugar para otro y ese dinero me sostuvo por un tiempo, no pude arreglar mi casa y perdí el lote donde vivía, ahora vivo en la casa de mi mamá" (SO)

"Poco a poco fue afrontando de forma improvisada su rol de padre y hombre cabeza del hogar para Fermín específicamente puesto que Alexander y Juan Carlos deciden ir con su madre para Barrancabermeja a estudiar. Todo esto conllevo con el pasar de los días a Robinson a perder el interés y la importancia por continuar estudiando y prepararse mejor para un futuro" (RD)

“Como consecuencia de la muerte de su padre Juan Carlos empezó a trabajar para pagarle la comida a su hermano a su mamá y para él, empezó a asistir poco a clases y por ende fue perdiendo el deseo e interés de superarse, sumado a esto su sentimiento de odio y la sed de 
Percepción de reparación en familias de víctimas de desaparición forzada | 112 venganza acabaron por ese momento cualquier "pensamiento bueno" y se decía que en ese instante lo menos importante era lo académico” (JD)

"Después de los hechos Fermín no pudo continuar sus estudios, debió asumir una vida improvisada (hacer las cosas al ensayo y error, para aprenderlas), le toco asumir una vida laboral activa (independiente) para garantizar su sustento” (FD)

“acabaron con un ejemplo para mí y para mis hijos, y acabaron con su proyecto de pronto él quería ser alguien mejor mas adelante” $R D$

La alteración en el proyecto de vida es uno de los daños más significativos, debido a que sus efectos se ven reflejados tanto a nivel individual como colectivo y a su vez limita el acceso a mejores oportunidades académicas, laborales y de vivienda, lo que supone una fuerte barrera para la consecución de una mejor calidad de vida. Gómez (2009), describe los cambios súbitos en el proyecto de vida individual, familiar y comunitario tras acontecimientos violentos, lo que dificulta el proceso de duelo, genera retraumatizaciones, disminuyen las expectativas de progreso, desaparecen los líderes o referentes al interior de un grupo y se genera una abandono de actividades económicas tradicionales.

A la luz de estos daños, es posible que los familiares pidan, como en el caso de la Masacre de la Rochela, ayudas en materia de vivienda, educación o trabajo, sin embargo se esperaría que realizaran de manera autónoma acciones para solventar estas necesidades.

Proximidad de los victimarios: como ha sucedido en varias regiones de Colombia, los grupos paramilitares han tomado parte en la vida cotidiana de las personas, especialmente de las que habitan en municipios y sus zonas rulares aledañas, a través de acciones represivas como el despojo tierras, asesinatos, torturas, desapariciones e imponiendo sus propias normas, afectando así la privacidad de las personas y constituyéndose en una amenaza para la seguridad de la 
Percepción de reparación en familias de víctimas de desaparición forzada | 113

población civil. La región del Magdalena Medio, región en donde ocurrieron los hechos de desaparición forzada objeto de eta investigación, ha sido militarizada históricamente por grupos armados tanto legales como al margen de la ley, los siguientes relatos muestran la cercanía con este tipo de grupos paramilitares:

"no era seguro ir a pescar porque uno no sabía si iba a regresar con vida y tampoco era bueno tener buena productividad en su finca, ya que era objeto de "vacunas" por parte de los grupos armados ilegales"(SO)

“Después de los hechos las cosas empeoraron, la presencia de los grupos paramilitares ilegales volvió muy difícil a vida en el campo hasta el punto en que los campesinos se volvieron desconfiados y aislados”. (RD)

“Como los paramilitares vivían en la región podían ser hasta vecinos, se perdió la confianza en las personas porque uno no sabía quién era o no. ” JD

"Se perdió la libertad de poder salir y llegar a cualquier hora a la casa, porque los paramilitares colocaban horarios en los barrios" JD

"no podíamos reclamar porque nos amenazaban, no podíamos frecuentar la finca porque ellos se querían apoderar del terreno" $A D$

"Ellos vivan en el mismo barrio que nosotros" EO

"la gente en el pueblo rumoraba que los grupos al margen de la ley que estaban en ese momento en el pueblo tenían que ver con la decisiones políticas que se tomaban en la administración” (SO)

"tuve una tentativa de reclutamiento forzado por parte de los paramilitares, lo cual tuve que irme del pueblo y eso fue un desplazamiento" EO 
La proximidad y poder de los victimarios deja como secuela un grave daño en la estructura social. La desaparición forzada de personas no solo afecta al individuo, sino a este en relación con su familia y comunidad. Es así como las estructuras ilegales comienzan a influir en las decisiones del estado y en ocasiones operan mancomunadamente con la Fuerza Pública. Según la Comisión Colombiana de Juristas (2004), la consolidación y expansión del paramilitarismo en Colombia, contribuyó a la actitud tolerante y de apoyo a los grupos de paramilitares por parte de la Fuerza Pública, lo cual facilitó la entrada y acción de estos grupos en zonas nuevas.

Tal permisividad hacia los grupos paramilitares ha permitido que estos, de manera arbitraria, involucren a la población civil en el conflicto armado, afectando el bienestar y tranquilidad de las familias y controlando sus actividades productivas y culturales.

Como se evidencia en este caso, los victimarios y la violencia persisten de manera estructural a pesar de los procesos de justicia transicional adelantados, en los cuales las autodefensas resurgieron como bandas criminales, así mismo, sucede con las situaciones posteriores a éxitos judiciales nacionales e internacionales, que igualmente pasará con el actual proceso de paz en el que se espera un escenario postconflicto, pero realmente será necesario un postacuerdo en el cual posiblemente perseveraren conductas antisociales debido a que la violencia ha generado hábitos transgeneracionales (Movimiento Nacional de Víctimas de Crímenes de Estado, 2009).

Percepción de inseguridad: luego de sucedidos los hechos de la desaparición forzada de Benjamín Duarte y Jeisson Duarte de La Ossa, los familiares fueron objeto de amenazas por parte de los perpetradores del crimen, lo que ha generado en ellos temor y amenaza a su integridad hasta el día de hoy. La inseguridad percibida, hizo que las familias se demoraran en 
entablar la denuncia del delito. De hecho una de las familias recientemente perdió a uno de sus miembros bajo circunstancias que sugieren que la muerte no fue accidental sino un asesinato. Los siguientes relatos demuestran el miedo e inseguridad percibidos por los familiares:

"Debido a las amenazas y al temor que estas me daban, no podía salir a la calle, porque parecía que me iban a matar, no podía pasar por mi lado una moto, un carro porque pensaba que ya me iban a matar, por lo tanto no podía ir a trabajar, con esto he tratado de luchar por muchos años y aunque he mejorado todavía siento temor y persecución... (SO)

"el miedo que tiene uno hizo perder la inclinación de hacer una carrera militar, el temor que en cualquier momento llegaran y acabaran con todo hizo perder la felicidad de la vereda y las ganas de seguir uno viviendo ahi"'JD

“Al principio de los hechos por aspectos de protección como nos amenazaban y nos dijeron que lo dejáramos de buscar, durante 2 años guardamos silencio, no informamos por miedo a las amenazas" JD

"Nunca he dejado de sentir miedo" JD

“Como nos quedamos viviendo en la finca, nos sentíamos en peligro por las amenazas, pero nunca nos ha pasado nada gracias a Dios..." RD

“pensaba que a mi también me podian hacer algo” AD

"tuve una tentativa de reclutamiento forzado por parte de los paramilitares, lo cual tuve que irme del pueblo y eso fue un desplazamiento" EO

El delito de desaparición forzada atenta contra la libertad y seguridad de las personas, situación que naturalmente atemoriza a las familias y comunidades, ocasionando que no solo se perciba el medio cotidiano como inseguro, sino que realmente aparecen acontecimientos amenazantes. Las intimidaciones recibidas tras la denuncia de la desaparición del familiar, el 
desplazamiento forzado, los intentos de reclutamiento forzado y el despojo de tierras son solo algunas de las consecuencias más comunes en este tipo de delitos de lesa humanidad.

Lira (2005) citado en Antillón (2008) plantea que el poder represivo del Estado tras una detención arbitraria, que equivale a una desaparición forzada, genera inseguridad, terror y sentimientos de desprotección en las personas, independientemente de sus ideas o participación política. De ahí que la percepción de inseguridad en los familiares sea una constante, más aún mientras no se obtengan respuestas efectivas por parte del estado para esclarecer los hechos e impartir justicia.

Cambio cultural: tras los hechos y la denuncia de la desaparición forzada de Benjamín Duarte y Jeisson Duarte de la Ossa, los familiares reportan cambios en su rutina y costumbres, que de alguna manera afectaron su calidad de vida. Por ejemplo, surgen amenazas contra la vida y la integridad, por lo que estos familiares ven la necesidad de proteger su vida y algunos se ven obligados a abandonar sus lugares de origen, surgiendo así el fenómeno de desplazamiento forzado, que contribuyó a la desintegración de estos núcleos familiares y afectó seriamente sus recursos económicos. En términos psicológicos, estos cambios culturales suponen una pérdida de apoyo social además de ser un potente generador de estrés crónico.

De igual manera, ciertas actividades cotidianas, como ir a pescar, labores propias de los campesinos, ir a la misa, entre otras costumbres, dejaron de ser seguras para los familiares. Las actividades de la vida cotidiana se empezaron a vivir como actividades peligrosas, pues la represión por parte de los grupos ilegales en esta región estaba dirigida a toda la población. Además, los participantes manifiestan que el paramilitarismo tomo parte en las decisiones de las autoridades de la región asumiendo el control sociopolítico de esta zona del Magdalena Medio. 
Soportar el desplazamiento conllevó a la pérdida de referentes culturales, pérdida de la relación con la tierra en estas familias de origen campesino y cambios en la propia identidad. A nivel social, se propicia una gran desconfianza hacia los demás, las redes sociales cambiaron totalmente, manifestando rechazo y prejuicios ante los hechos. A continuación se presentan narraciones que ilustran el cambio cultural vivido por los familiares:

“Cuando desaparece mi hijo todo se me truncó, mi vida dio un vuelco de dolor y tristeza, me tocó desplazarme debido a la denuncia que puse, tuve que rodar a barranca por 3 años cuya permanencia no fue consecutiva, es decir, habito por distintos lapsos (iba a Yondó por días a ver a su progenitora enferma) a sufrir sin casa, sin trabajo, sin saber qué hacer con mi dolor y con esta situación” (SO)

“Después de los hechos las cosas empeoraron, la presencia de los grupos paramilitares ilegales volvió muy difícil a vida en el campo hasta el punto en que los campesinos se volvieron desconfiados y aislados”. (RD)

“Después de los hechos no volví a participar de la santa misa los domingos, como era de costumbre asistir todos los domingos (FD)

"todo el mundo en el pueblo sabía que los paramilitares tenían infiltradas las autoridades militares y policía” SO

“tuve que irme a vivir con una tía a otro pueblo donde todo era nuevo y mejor” EO

“Después de los hechos tuve que cambiar de vivienda, dejar a las personas más conocidas y el temor de hablar de los hechos causó desconfianza en todas las personas" JD

“... (Suspiro), se perdió la tranquilidad de la vereda y de las personas...” JD 
Percepción de reparación en familias de víctimas de desaparición forzada 118

"Cuando llegué a Barranca me toco aprender otras costumbres, la gente hablaba diferente, el colegio era diferente, mi acento era de campesino y algunos compañeros se burlaban" $A D$

Antillón (2008), al documentar un caso de desaparición forzada en México, describe impactos similares a los encontrados en los familiares de Benjamín Duarte y Jeisson Duarte de la Ossa sobre las costumbres y cultura, en donde se inhibe la participación política de la población, hay ruptura de creencias básicas, inhibición de mecanismos de afrontamiento comunitarios, impacto negativo en el desarrollo sociocultural y polarización social.

\section{Categoría 3 Percepción de reparación}

El estado colombiano ha impulsado varias iniciativas para afrontar la violación de Derechos Humanos por parte de grupos armados ilegales, una de ellas es la promulgación de la Ley 975 de 2005 (Ley de Justicia y Paz), en donde se establecen como formas de reparación la indemnización, la rehabilitación, la satisfacción y las garantías de no repetición. En la sesión de grupo focal, se pudo evidenciar que los familiares no ven una forma ideal de reparación, pues para ellos es imposible resarcir los daños causados por la desaparición de sus seres queridos. Sin embargo, tienen ciertas expectativas sobre el proceso legal y búsqueda de la verdad a pesar de que hasta el momento es poco lo que han obtenido en el sentido de la reparación integral y las medidas de indemnización económica, por ejemplo en el caso de Benjamín Duarte una dificultad en el proceso de Justicia y Paz es que los autores materiales del hecho están fallecidos por muerte violenta y Rodolfo Morales comandante del bloque estaba postulado sin embargo nunca lo capturaron y en la actualidad goza de libertad y lo excluyeron del proceso, todo lo anterior obstaculiza la consecución de la verdad, el hecho de no conocer el paradero de los cuerpos de sus familiares por haber sido arrojados al rio según lo confesaron los perpetradores de crimen, 
dificulta cualquier proceso de reparación y de construcción de verdad, memoria histórica como medidas de satisfacción, asimismo desde hace 2 años se encuentran esperando asignación de fecha para el incidente de reparación.

Por otra parte, en el caso de Jeisson Duarte de la Ossa aunque en justicia ordinaria ya se dictó sentencia condenatoria a un civil y otros paramilitares, los familiares víctimas no ha obtenido ninguna medida de reparación frente al daño moral ni reparación por vía administrativa, quedando en ambos casos aun en espera de la indemnización. Además, los familiares manifiestan inconformismo especialmente frente a las garantías de no repetición pues los grupos ilegales que aun hacen presencia en la región donde habitan los familiares se han ido reorganizando, y en otras ocasiones a raíz de las sentencias emitidas han tenido que afrontar nuevos episodios de amenazas. Los relatos que dan cuenta de la percepción frente a la reparación que tienen los familiares participantes se muestran a continuación.

Percepción de indemnización: los indicadores de indemnización se dan en varios niveles, uno de ellos es el que tiene que ver con el daño físico o mental, frente al cual los familiares manifiestan que nada es suficiente para sentirse como antes y que la desaparición de sus familiares ha generado en ellos huellas imborrables a nivel mental, JD uno de los hijos de Benjamín Duarte lo expresa de la siguiente manera: "Nunca va a ser igual y aunque en ese tiempo era menor tampoco sabría cómo describirlo, son cosas que quedan en la mente y nunca se podrán borrar. Cuando se es menor, las cicatrices son más profundas”

La desaparición forzada de Benjamín Duarte y Jeisson Duarte de la Ossa generó en sus familiares pérdida de oportunidades de empleo, educación y prestaciones sociales, lo que según la Ley de Justicia y Paz sería objeto de indemnización, en tal sentido uno de los familiares percibe la indemnización de la siguiente manera: "No sabría cómo especificar una 
indemnización pues pienso que cualquier intento sería en vano en términos de dinero, pero me gustaría que me apoyaran a terminar mi carrera profesional..." JD. Otro familiar expresa la expectativa que tiene frente a la indemnización así: "perdi mi estabilidad laboral, por eso quisiera que el Estado entregue proyectos productivos para una estabilidad laboral” RD.

Los hechos de desaparición forzada también generaron en los familiares daños materiales y la pérdida de ingresos, incluido el lucro cesante, frente a este tipo de daño los participantes tienen puntos de vista opuestos, para algunos la indemnización en este sentido podría ser algo positivo, mientras que para otros lo material tiene poca importancia y no responde a la reparación que esperan por parte del estado, así lo demuestra lo narrado por algunos familiares: “tomaría lo económico como una herencia de mi padre para arreglar su finca y mantenerla como él quería." $R D$

“eso es dinero sucio con sangre de nuestros familiares, perdi mi tranquilidad, mi trabajo, mi casa y debería ser indemnizada por ello, por la violencia de este país, no porque perdí a mi hijo, él no tiene precio..." SO

Al reflexionar sobre una posible indemnización $\mathrm{AD}$ dice: “lo único que quiero es que le ayuden a encontrar el cuerpo de mi padre y que los culpables del hecho paguen por este delito pero que antes digan toda la verdad en lo que tiene que ver con motivos y responsables de los hechos, pude salir adelante solo, ahora no necesito plata."

EO al responder esta pregunta deja claro que: “...el dinero que le puedan dar ya no va a cerrar las heridas que dejó este hecho violento pues el daño que me hicieron a mí y a mi familia no tiene precio."

JJ refiere que: "como reparación pido un castigo para las personas que sean encontradas culpables del hecho y que no se limite todo a una reparación económica." 
Percepción de reparación en familias de víctimas de desaparición forzada 121

AD manifiesta: "La indemnización sería utilizada para el estudio de sus hijos pero no sabe cómo cuantificar esta pérdida pues aún no ha podido realizar el duelo y se niega a aceptar que su ser querido pueda estar muerto."

Es una constante en las familias afectadas por estos hechos, el no tener suficientemente claro qué implica para ellos un escenario de reparación, cómo garantizar la memoria de sus víctimas y la satisfacción de un derecho como víctimas que son, la reparación se les convierte en una especie de " sensor moral", frente a la posibilidad de emprender acciones legales y administrativas tendientes a su reparación, sienten estar haciendo algo indebido, sumado a esto hay una desinformación social, que por esta razón, censura el legítimo derecho de las familias sobrevivientes a ser reparados, so pena de ser apreciados por casi el conjunto de la sociedad como vendiendo por pocos pesos su dolor y la memoria de sus familiares. Aunque los actuales instrumentos de justicia transicional han mejorado en algo la percepción social, aún se mantiene un temor en las victimas de adelantar estos procesos, sin embargo se puede inferir que para algunos de los participantes el hecho de ser destinatarios de una indemnización económica les aportaría colateralmente a mejorar su proyecto de vida pero no a mejorar su estado emocional.

Frente a los perjuicios morales y sociales los familiares participantes consideran que no es posible compensar con dinero los daños ocasionados.

A su vez, Ulloque, M (2009) manifiestan que es necesario que la reparación a las víctimas no se aplique sobre el "daño" sino sobre los derechos, es decir, no puede limitarse al aspecto económico y mucho menos a suplir la responsabilidad del Estado en lo concerniente a la asistencia social (salud, vivienda, educación, etc.). Debe tomar como principios el concepto de reparación integral internacional en el contexto de una justicia transicional: Restitución del derecho, Indemnización, Rehabilitación, Satisfacción y Garantías de no repetición. 
En este sentido, para los familiares la indemnización pasa a un segundo plano, dando prioridad a otras medidas de reparación como la sanción a los responsables, el conocimiento de la verdad o la ubicación de los cuerpos.

Aunque los familiares perciban que la indemnización nunca será suficiente para reparar su tranquilidad, aceptan su derecho a solicitarla y no consideran lo pecuniario como algo aislado, porque se generaron gastos emergentes y el lucro cesante. Adicionalmente, lo económico lo asocian a la asistencia jurídica y en salud, es decir al acceso a la justicia y al mejoramiento de su salud a través de un tratamiento oportuno.

“....Indemnización o carta cheque, como sea, el pago de mi familiar, que es nada, siempre es un sacrificio, una burla para tenerla, uno va y se pierden los papales que llevo en la defensoría o en Acción social, le piden otra vez los papeles, extrajuicios que cuando valen, ahh, el gasto del bus hasta Barranca, ahh y sin olvidar a nosotros lo que nos han desaparecido un familiar nos piden, eso... mmm ... lo de muerte presunta... es eso?, y más plata para poner eso y más años de espera... para que... (Silencio)...” ED

“... ahh si, ¿y tanto papel, tiempo y plata gastada para qué? Si yo cómo hermano no voy a recibir pago por acción social..." EO.

Se evidencia entonces que la ruta a la indemnización ha generado fuertes impactos a nivel psicológico en los familiares, además que desesperanza aprendida por el tiempo y respuesta que han tenido del proceso, como también lo refiere Paris (2009) en su investigación: hoy en día en la práctica es posible notar como para recibir la ayuda humanitaria, se exige adelantar el proceso de Muerte Presunta, con las consecuencias como castrar la oportunidad de un beneficio internacional y para el contexto nacional esa persona ya sale de la lista de desaparecidos y evidente obstáculo en la reparación de los familiares de desaparecidos, especialmente en su 
Percepción de reparación en familias de víctimas de desaparición forzada 123

rehabilitación. Asimismo la reparación integral de los familiares debe responder a las necesidades de búsqueda de sus familiares pero también a garantizar la indemnización, la rehabilitación, las medidas de satisfacción y las garantías de no repetición de acuerdo con los estándares internacionales.

También se observa que cuando a los familiares se les pregunta por lo que esperan en la indemnización, ellos aluden otros aspectos como acceso a un buen servicio de salud o una asistencia jurídica de calidad. Así lo sugiere Beristain (2008) en el sentido que las medidas son integrales y el cumplimiento de unas favorece el de las otras.

Percepción de rehabilitación: este tipo de reparación incluye la atención médica, psicológica, los servicios jurídicos y sociales. Frente a esto la percepción de los familiares es la misma que se incluyó en la indemnización, quienes consideran que los servicios de rehabilitación deben implementarse de manera continua y desde el momento inmediato a la ocurrencia de la desaparición forzada: "Poder tener el acompañamiento psicológico permanente o por lo menos hubiese sido ideal tenerlo los primeros años" $J D-A D$ - SO

“que el acompañamiento psicológico no se de 10 años después a las víctimas más recientes, como nos pasó a nosotros" EO

Por otro lado, los gastos de asistencia jurídica o de expertos, medicamentos, servicios médicos, servicios psicológicos que requieren los familiares víctimas de la desaparición forzada de Benjamín Duarte y Jeisson Duarte de la Ossa no han sido cubiertos de manera continua, además para tenerlo debían viajar hasta Barrancabermeja y estos deberían haber sido otorgados desde el momento inmediato en que sucedieron los hechos según la opinión de los participantes 
Percepción de reparación en familias de víctimas de desaparición forzada 124

“crear una entidad especial en el municipio de Yondo para la ayuda y orientación a las víctimas, porque en la actualidad no hay entidades que lo hagan y la gente está sin mucho conocimiento y atención" SO

Respecto a la anterior perspectiva, la Ley 1448/11 en su artículo 137, para responder a la rehabilitación como medida de reparación, brinda como respuesta el Programa de Atención Psicosocial y Salud Integral a Víctimas del Conflicto Armado, en adelante PAPSIVI, el cual recientemente ha formado parte de las medidas de asistencia y teniendo en cuenta el enfoque psicosocial, la ley estipula que el gobierno nacional debe implementar un programa en el que se incluyan medidas de rehabilitación tanto a nivel individual como colectivo, orientadas a superar las afectaciones en salud y psicosociales relacionadas con el hecho victimizante, que permitan a las victimas desempeñarse en su entorno familiar, cultural, laboral y social y ejercer sus derechos y libertades. Dicho programa, PAPSIVI, debe ser ejecutado por el Ministerio de Salud y Protección Social mediante Sistema General de Seguridad Social en Salud (SGSSS), del Sistema Nacional de Reparación y Atención Integral a Víctimas del Conflicto Armado (SNARIV) y de la sociedad civil. Sin embargo, este programa depende de la situación territorial en salud en la que se encuentre el municipio de Yondó, motivo por el cual seguramente deberán trasladarse hasta Barrancabermeja para recibir la atención.

La postura de los participantes permite identificar un nuevo escenario para la atención a las víctimas, derivada del sistema de salud y adicionalmente del poder ejecutivo, es decir, brindar una contención inicial que no dependa de tener éxitos legales.

La obtención de una atención en salud se dificulta por la falta de un ente responsable de materializar las intervenciones terapéuticas requeridas por las víctimas, antes y durante el proceso judicial. 
La tendencia actual de las cortes ha evolucionado hacia otorgar cada vez más el tratamiento médico y psicosocial integral de modo que no resta importancia a la este tipo de reparación.

Relacionando los hallazgos de esta categoría con los daños encontrados en estos participantes a nivel psicológico y psicosocial tales como rasgos de ansiedad, depresión, paranoides, evitativos, sentimientos de ira, de culpa, ruptura de las relaciones familiares, se esperaría que los familiares solicitaran esta medida de reparación y lo que se observa es lo contrario, y es que se han adaptado a vivir con el malestar, se han desensibilizado, habituado, dejando de lado expectativas positivas frente a esta medida.

Esta percepción pesimista frente a una rehabilitación se puede interpretar de dos maneras: la primera que tienen desesperanza en el sistema y la segunda que han adoptado una estrategia de afrontamiento inadecuada que es la evitación, que se hace evidente cuando los familiares tienen una reexperimentación traumática al hablar de lo acontecido por hecho de participar en la entrevista y el grupo focal. Participar en una investigación sobre la desaparición de Benjamín Duarte y Jeisson Duarte De la Ossa hizo revivir los hechos traumáticos acontecidos hace alrededor de 10 años, disparó reacciones de angustia y manifestaciones psicosomáticas. Esto hizo que algunas de las personas que al principio consintieron en participar en la investigación al final lo hicieran con cierta prevención.

Percepción de satisfacción: Las medidas de satisfacción están encaminadas a la verificación de los hechos y conocimiento público de la verdad, restauración de derechos y actos de desagravio, sanciones contra los perpetradores, tributos conmemoraciones, entre otros. Frente a la verificación de los hechos y el conocimiento público de la verdad, medida contemplada dentro de la reparación integral, los participantes no han recibido ningún tipo de reparación 
derivado del proceso de justicia y paz y esperan que los responsables de la desaparición de los hechos digan la verdad de manera pública con el fin de recuperar la dignidad humana: "que las personas que tuvieron que ver y aun vivan, digan la verdad ¿por qué lo hicieron? En un medio en que los demás puedan saber. Hace 10 años que no sé nada de mi papá...” JD y RD

“hacer publicaciones para contar la verdad de los hechos y la historia de mi hijo para limpiar su honor y dignidad como memoria histórica." SO

La aplicación de sanciones judiciales o administrativas a los perpetradores no ha sido del todo aplicada en los casos de la desaparición de Benjamín Duarte y Jeisson Duarte de la Ossa y sus familiares hasta el momento no han visto alguna sanción tangible hacia todos los perpetradores, por lo cual aún esperan que se haga justicia, así lo expresa uno de los familiares: “quiero justicia total para la persona que entregó a mi hermano a los paramilitares.” EO

Respecto a la restauración de los derechos y actos de desagravio, los familiares de Benjamín Duarte y Jeisson Duarte de la Ossa no han recibido ningún tipo de compensación por parte de los postulados, además uno de los perpetradores que confesó el crimen fue excluido del proceso de justicia y paz y otro murió, dificultándose así el proceso de reparación. SO refiere al respecto "algunos de los culpables han recibido su castigo, como el señor Pironieta y otros paramilitares, pero que, sin embargo, todavía falta que sean condenados los autores intelectuales de este hecho, y ya no sé qué sea mejor porque con la condena de Pironieta su esposa no ha mandado amenazas por ser los “culpables de que él este en la cárcel."

Las conmemoraciones y homenajes a las víctimas son otra forma de medida de reparación de satisfacción para conservar la memoria histórica frente a los hechos que debe ser concertada con las victimas pero que hasta el momento no se ha hecho, al respecto uno de los 
familiares manifiesta su anhelo: "me gustaría que le pusieran el nombre de mi padre a la escuela de Yondó o al coliseo como herramienta de memoria histórica. ” JD

La búsqueda e identificación de Benjamín Duarte y Jeisson Duarte de la Ossa ha sido una de las situaciones más complicadas en el proceso adelantando pues no se tienen noticias de sus paraderos ni del lugar exacto donde desaparecieron, esto ha incrementado el dolor en sus familiares y prolongado el duelo, haciendo que se pierda toda esperanza de reparación: "no me siento preparado para ser reparado, porque lo único que sería es que le devuelvan el cuerpo de mi hermano." EO

“nunca voy ni vamos a ser reparados, solo quería saber el punto exacto en donde tiraron a mi papá al río y eso no lo voy a saber porque el que lo hizo lo mataron y el jefe paramilitar lo excluyeron de justicia y paz. ”JD

Frente a las percepciones de los participante Paris (2009) también refiere en su investigación que el derecho a la verdad es la más grande dificultad en torno a la verdad; no obstante las confesiones de los miembros de grupos armados, que relatan los hechos pero no hacen referencia al paradero de las víctimas, lo que es considerado un problema de administración de la justicia y por parte de la fundación; a lo que puede sumarse que hay un gran número de miembros de grupos armados que no se han desmovilizado aún y por tanto el panorama sobre la información que puedan brindar es desolador.

SO "me gustaría que la dignidad y el buen nombre de la víctima directa y de la familia se limpien de todos los señalamientos y estigmas sociales de los cuales fueron acusados tanto por los paramilitares como por la comunidad, por medio de difusión en el periódico y la verdad en una audiencia de versión libre." 
JJ "me gustaría que colocaran una placa conmemorativa con el nombre e historia de vida de mi hermano en el centro del parque de Yondó."

Hasta el momento no ha habido una disculpa pública que incluya el reconocimiento de los hechos y la aceptación de responsabilidades por parte de los postulados, no obstante los familiares participantes esperan que esto se logre algún día: “Manifestación pública de perdón y arrepentimiento de los postulados y publicación de la verdad”SO.

Por otra parte, es importante conocer los beneficios socioeconómicos y el programa de reincorporación a la vida civil de las personas alzadas en armas a cargo del Ministerio del Interior y de Justicia. El Programa tiene los siguientes componentes: atención humanitaria, salud, educación formal y no formal, seguridad, jurídica, atención psicosocial y sistema de información dentro del marco de la Ley 975/05, puesto que estos beneficios han sido percibidos por las víctimas como privilegios que ellos no han tenido, afectando de esta manera la disposición para la generar mecanismos de reconciliación, procesos de perdón y confianza con el Estado.

$R D$ manifiesta lo siguiente al respecto “... el Estado primero se preocupó por darle beneficios a los asesinos que a nosotros que somos las víctimas, a ellos les da subsidio por haber matado gente, ahh, eso es inaudito"

EO “conozco a unos paramilitares que estudiaron por el estado, los protegen, y yo que fue a quien me quitaron mi hermano, he sufrido, no estudie porque mi mamá se desplazó, no tengo nada ni me han brindado apoyo para estudiar..."

Otros familiares expresan que no conocen si los victimarios han tenido acceso a cursos de capacitación en materia de DD.HH., sin embargo se percibe un sentimiento de resistencia y rabia por el hecho que los perpetradores obtuvieron beneficios mucho antes que las víctimas, cuando piensan que se debió llevar a cabo inversamente. 
Aunque los familiares se muestran insatisfechos de lo logrado hasta el momento, no descartan la posibilidad de obtener medidas de dignificación y conmemoración de los familiares desaparecidos.

En contraste con lo encontrado como expectativas de rehabilitación, allí las víctimas parecen abandonar sus pretensiones y aquí perseveran en las mismas y esto a pesar de notar que los victimarios recibieron beneficios antes que ellos.

Particularmente se observa que los participantes proponen estrategias de reparación diferentes, lo cual da cuenta de su creatividad y participación además de la versatilidad de esta medida.

Garantías de no repetición: son acciones, medidas y procesos encaminados a evitar las repetición de violaciones a los DDHH y DIH, generar cambios en el funcionamiento de las instituciones, transformar factores estructurales de la violencia y lograr una incidencia positiva en la cultura política, con el fin de fortalecer la política de prevención general según la Ley 1448/11 articulo 149 (p. 68)

Frente a este tipo de reparación los familiares participantes perciben que las autoridades no han hecho un control efectivo sobre los grupos paramilitares y las bandas criminales presentes en el municipio de Yondó (Antioquia), pues estos aún operan en la región del magdalena medio, han recibido amenazas e incluso se está analizando que una muerte reciente de otro familiar esté relacionada con algún grupo paramilitar, uno de los familiares expresa: "el Estado no ha hecho nada, en Yondó siguen los paramilitares, se están reagrupando y no han hecho nada, están apareciendo muertos sistemáticamente, incluso me mataron a mi hijo" SO. Otro familiar habla del hecho reciente de la muerte de un miembro más de la familia: "no creo en las garantías de repetición, es algo imposible, mire lo que le acabo de pasar a mi familia” EO. Frente a lo 
anterior los familiares esperan que mejoren las condiciones de seguridad: "que el Estado ponga medidas de seguridad para vivir con más tranquilidad” JD

SO "uno no sabe que es peor, si denunciar o no, mire mi caso, la mujer del señor que metieron a la cárcel por el caso de mi hijo, apenas se enteró que fue "por mi culpa" por denunciar, me mando unos tipos a la casa, me amenazo, yo denuncie eso y nada paso,"

La desaparición forzada de Benjamín Duarte y Jeisson Duarte de la Ossa, no responde a un hecho aislado, sino que se ha configurado como una forma de control sistemático y generalizado, por parte del paramilitarismo en varias regiones de Colombia. Este grupo aún tiene influencia en la vida cotidiana, en el manejo económico y político de la jurisdicción del magdalena medio, lo que se ha constituido como una forma de crimen organizado, que el Estado no ha sido capaz de frenar, a pesar de haber puesto en marcha la Ley 975 de 2005 más conocida como Ley de Justicia y Paz.

Se observa entonces que el Estado tiene en su norma clara las medidas para garantizar la no repetición de los hechos, sin embargo principales objetivos como evitar la repetición de hechos o conductas que generen violaciones a los Derechos Humanos en el nivel individual y colectivo, generar contextos de convivencia pacífica y reconstruir el tejido social en la prácticas del contexto real está contemplando vacíos y dificultades con el control de grupos al margen de la ley en los municipios como el de Yondó y Barrancabermeja, por otra parte con el ánimo oportuno de iniciar procesos de reconciliación en el país según lo soporta la Ley 975/05 en su artículo 48 y 49 se esta fortaleciendo el Estado social de derecho y de la ciudadanía logrando articulaciones con ONG`S, víctimas del conflicto armado e institución desarrollar la ruta de activación de mecanismo de búsqueda urgente a desaparecidos a nivel nacional, se espera que este gran logro sea de difusión y comunicación general como garantía de no repetición. 


\section{Categoría 4 Revictimización}

A partir de los relatos se identificó que los familiares de las víctimas de desaparición forzada objeto de esta investigación, han pasado por circunstancias de revictimización, también conocida como victimización secundaria, acompañadas de la impunidad derivada del lento avance del proceso judicial adelantado.

Según Echeburúa, Corral y Amor (2004), citado en Hernández (2011) se entiende como revictimización toda acción u omisión que empeore el estado físico y/o psíquico de la víctima cuando busca ayuda y se relaciona con el sistema legal, instancias en las que puede encontrar insensibilidad, incomprensión, nuevas agresiones, que se ponga en tela de juicio, dilaciones o falta de información. Así mismo, Cabrera y Martin B (2000) coinciden en que los mecanismos de impunidad consisten en obstaculizar las investigaciones de manera intencional, alterar pruebas, dificultades operativas en las exhumaciones, amenazas o intimidaciones a los testigos o agentes de la justicia, corrupción, falta de colaboración de jueces y fiscales o retrasos injustificados en los procesos.

De acuerdo a lo anterior, los familiares participantes dan testimonio del maltrato y negligencia institucional recibido: “cuando uno iba a preguntar por el caso la policía no le daba respuesta a uno o sea hacían como si no fueran con ellos” SO. Respecto a esta percepción se puede inferir que en algunas instituciones públicas se ha vulnerado el derecho que tienen las víctimas a la verdad y justicia contemplado en la Ley 975/05, asimismo los que contempla en el 2006, la Corte Constitucional que dio uno de los más importantes pronunciamientos mediante la sentencia C-370 de 2005 donde refiere que al interior de del proceso contemplado en la ley 975 de 2005 tienen el derecho a participar en todas las etapas y a acceder directamente al expediente desde la iniciación del proceso, esto en ejercicio de sus derechos a la verdad, a la justicia, a la 
reparación y a las garantías de no repetición, es por ello que Ulloque, M (2009) en este sentido, todas la instituciones estatales comprometidas en la aplicación de la ley 975 de 2005 deben ser especialmente cuidadosas en el respeto y garantía de los derechos de las víctimas, de conformidad especialmente con los artículos 1 y de esta ley.

De esta forma, se evitaría grandes reprocesos en los familiares, revictimizaciones y sentimientos de desconfianza para el acceso a la justicia.

Por otra parte, al acudir a las autoridades las víctimas han tenido que reiterar el relato de los hechos sin que se logren grades avances en la investigación: “hemos tenido que acudir a varias instituciones y en todas vuelven a preguntarnos lo mismo, volvemos a contar lo que pasó pero de nada ha servido” RD. Los familiares de Benjamín Duarte y Jeisson Duarte de la Ossa manifiestan que han recibido información errónea o confusa por parte de funcionarios: “la falta de conocimientos a quien acudir, algunos funcionarios, nos mandaban a otras cosas sin asumir su responsabilidad" JD-SO.

En similitud hace referencia, Paris (2009) los procesos de revictimización por parte de los funcionarios esto cobra especial importancia en la medida en que su afectación no representa una base sana de interacción con los funcionarios judiciales, con quienes al recibir posibles tratos indiferentes o displicentes, es muy difícil construir bases sólidas de entendimiento y mutua colaboración. Esto es, al daño ocasionado por la desaparición forzada de su familiar se suma el gasto emocional que implican los procesos de investigación, allanando aún más el terreno para hacer difícil que el proceso sea entendido como reparador desde sus inicios y para la generación de acciones de rehabilitación psicosocial.

También, reportan que ha habido dilación en los procesos judiciales y de reparación por parte de autoridades: “llevamos 10 años de esperar la verdad de los hechos y nada, ahora con el 
proceso de justicia y paz ya llevamos 2 años esperando la fecha para la audiencia de reparación" JD

"La policía tenia capturado al jefe paramilitar de Yondo, luego no se porque lo soltaron, y justicia y paz lo solicita cuando está libre, y él nunca se presentó porque si lo hacia lo cogían preso, yo les decía a los policías donde estaba, le daba la dirección y nunca lo quisieron capturar hasta que lo sacaron del proceso" JD

En el municipio de Yondó (Antioquia), durante la última década, la entidad de control encargada de brindar atención y orientación a las víctimas es la personería y la defensoría del pueblo, sin embargo por la "permeabilidad" de la institución con los grupos al margen de la ley según declaraciones de los participantes y el Banco de datos CINEP y Corporación Nación (2004), la falta de confianza que tienen las personas con la institucionalidad estatal y el poco conocimiento de los funcionarios sobre el delito de desaparición forzada y los mecanismos de búsqueda urgente, las víctimas se han trasladado a Barrancabermeja o Puerto Berrio a buscar orientación, asesoría o atención para la denuncia o investigación de los hechos eficaz y verazmente, es por esta razón que la mayoría de familiares víctimas desean que en el municipio de Yondó se asignen unos asesores de la Unidad de Atención y Reparación Integral a Víctimas que estén en la capacidad de brindar una información oportuna y segura, y además que los capacite sobre sus derechos según lo normado en la Ley 1448/11 y otros instrumentos legales.

Se observa entonces que entes como algunas alcaldías y gobernaciones no generan en la mayoría de los casos mecanismos de implementación que ejecuten de manera responsable los planes formulados desde el nivel nacional en cuanto a las obligaciones legales que les competen en la Ley 975/05. Adicionalmente, la falta de recursos técnicos, económicos y humanos genera obstáculos en la consecución de los objetivos planteados en la ley y el compromiso fiscal no es 
concordante con las necesidades que las instituciones tienen para el sostenimiento de sus actividades en desarrollo de la política, lo cual va en contravía con lo dispuesto en la declaración sobre la Protección de Todas Las Personas Contra Las Desapariciones Forzadas en su art 13:

Los Estados velarán por que la autoridad competente disponga de las facultades y los recursos necesarios para llevar a cabo la investigación, incluidas las facultades necesarias para exigir la comparecencia de testigos y la presentación de pruebas pertinentes, así como para proceder sin demora a visitar lugares.

Por otra parte, el proceso de muerte presunta, reglado por el artículo 10 de la Ley 589 de 2000, pretendía tener efectos sobre los derechos civiles de los afectados; sin embargo a la fecha de entrevista con los participantes del proyecto es utilizado como exigencia para la obtención de la ayuda humanitaria, lo que repercute en mayores y más tortuosos obstáculos para el goce efectivo de los derechos de los familiares de desaparición forzada, obligando a los familiares a adelantar los procesos por muerte presunta, desconociendo su dolor y las afectaciones emocionales que esto pueda generar en ellos.

“....Indemnización o carta cheque, como sea, el pago de mi familiar, que es nada, siempre es un sacrificio, una burla para tenerla, uno va y se pierden los papales que llevo en la defensoría o en Acción social, le piden otra vez los papeles, extrajuicios que cuando valen, ahh, el gasto del bus hasta Barranca, ahh y sin olvidar a nosotros lo que nos han desaparecido un familiar nos piden, eso... mmm... lo de muerte presunta... ¿Es, eso?, y más plata para poner eso y más años de espera... para que... (Silencio)...” ED

“...aunque en audiencias hayan confesado que mi hijo está muerto, mi corazón me dice que no, que él está vivo, lo he visto en sueños, para que tenga que ser yo misma quien lo declare por muerte presunta para acceder a la indemnización..." SO 
Asimismo, Paris (2009), refiere que Es fundamental mencionar que una de las formas en que los familiares de víctimas de desaparición resultan revictimizados es la "necesidad" que se establece por parte de algunos funcionarios judiciales de hacer adelantar el proceso de muerte presunta, con lo cual se da paso a derechos civiles entre los familiares respecto de los bienes y activos con los que contaba el desaparecido. La superación de este obstáculo requiere de un énfasis en la capacitación de los funcionarios judiciales que debe ser objeto de atención en el menor tiempo posible; toda vez que respecto de los derechos civiles de los familiares la Ley 589 de 2000, p.55-56.

Se observa que algunos de los familiares han tenido que afrontar revictimizaciones que surgen de las relaciones con el sistema jurídico y el aparato del Estado, asimismo como consecuencia de las sumadas situaciones de injusticia, re experimentación de la narración de los hechos y negligencia por algunos funcionarios públicos sienten el fenómeno de la desesperanza que en ocasiones hay la probabilidad de que la víctima se convierta con el tiempo en agresor verbal por la defensa de sus derechos o simplemente renuncie y deserte en la consecución de los mismos.

Lastimosamente se evidencian encuentros negativos de las víctimas con el sistema penal, lo cual depende de la atención recibida por los profesionales, las instituciones y la deficiencia en las rutas de atención establecidas para atender delitos de reparación forzada. 
Percepción de reparación en familias de víctimas de desaparición forzada $\mid 136$

\section{Conclusiones}

Para la presente investigación se contó con la participación de dos familias afectadas por el delito de la desaparición forzada de Benjamín Duarte y Jeisson Duarte de la Ossa, este delito de lesa humanidad, es un evento que ha generado en sus familiares afectaciones a nivel individual y familiar, en tal sentido, este trabajo investigativo requirió de una revisión teórica y metodológica que permitió identificar la opinión y percepción de las víctimas frente a las acciones de reparación integral adelantadas para mitigar las afectaciones de los hechos violentos, pues a pesar de contar con avances normativos y procedimentales, es poco lo que existe en materia de reparación desde las necesidades y subjetividad de las víctimas. Adicionalmente, son ellas las fuentes autorizadas para calificar la eficacia de los procesos judiciales y sus percepciones pueden retroalimentar el sistema judicial, para así orientar hacia mejores prácticas en torno a su restablecimiento de derechos.

Al abordar las expectativas de reparación en los familiares participantes, se encontró que desean obtener actos de dignificación de la memoria de sus víctimas de manera primordial y acceso a la verdad, pasando a un segundo plano las medidas relativas a indemnización económica, las cuales les generan gran ambivalencia en torno a que las merecen, las necesitan, empero la aceptación de dineros también tiene una connotación negativa, debido a que esta matizada por el precio de su dolor y la perdida de sus familiares en relación con la afectaciones encontradas.

Adicionalmente, el daño psicológico y psicosocial en estas familias es muy notorio y latente aún con el paso de los años, no obstante, las víctimas no manifiestan grandes expectativas en torno al tratamiento médico y psicológico, como quiera que se han habituado a vivir con la situación de desaparición del familiar y es tal la dilación de las respuestas judiciales, que las 
medidas de rehabilitación pasan a un tercer nivel. Esto último, demuestra que los amplios plazos del avance judicial, afectan negativamente la percepción de reparación en las víctimas, pues estas terminan declinando sus derechos y solicitando apenas unos mínimos en comparación con todo lo que podrían acceder.

Aunque estos hallazgos tienen poca posibilidad de generalización, en razón a que penas se derivan del estudio de caso de dos familias, permitieron ilustrar sobre elementos cruciales de la subjetividad de los beneficiarios del sistema de justicia, lo cual se contrapone a la política y prácticas de reparación administrativa genérica y en equidad para todas las víctimas, convirtiéndose en una tendencia que ha desarrollado la implementación de la Ley 1448 de 2011, aunque es comprensible este lineamiento, por el elevado número de víctimas, esta situación desconoce el derecho a la diferencia, a la singularidad de los casos, y sobre todo, a las expectativas particulares de los familiares de las personas en condición de desaparición forzada, de modo que se está vislumbrando dos aristas: una, la política de estado de una reparación general igualitaria y otra, la de las víctimas que reclaman un restablecimiento de derechos particular y dialogado conforme a sus expectativas.

Así mismo, se logró profundizar en el análisis de las lesiones psicosociales encontradas, las cuales coinciden con lo esperado para este tipo de delitos y con lo documentado en otros casos latinoamericanos. De esta manera, se constata la persistencia del sufrimiento psicológico como consecuencia del lento avance del aparato judicial, situación que con el trascurso del tiempo y los años en búsqueda de respuestas, también afecta todas las relaciones y áreas de desarrollo del individuo, es decir, sus relaciones inter e intrapersonales no continúan con la misma motivación que antes tenían, evidenciándose un impacto psicosocial en los familiares participantes. Cada uno de ellos, ha vivido los hechos victimizantes de manera particular, para 
algunos es preferible evitar hablar de lo sucedido, para otros hablar constituye una forma de desahogo y reclamación de derechos, no obstante, todos coinciden en que el hecho de desconocer el paradero de sus seres queridos, ha prolongado los procesos de duelo y síntomas como el llanto, los sentimientos de tristeza, estrés, ansiedad, desconfianza, miedo permanente y el aislamiento social, se mantienen, lo que a su vez dificulta ver materializada toda intención de reparación integral ofrecida por el estado a los familiares.

Adicionalmente, dentro de los impactos psicosociales encontrados, se identifica que a nivel cultural estas familias son de origen campesino, se generaron cambios en su vida cotidiana y en la de amigos y vecinos, debido a que el evento de la desaparición forzada de Benjamín Duarte y Jeisson Duarte de la Ossa no es un hecho aislado, sino que se trata de un delito generalizado en la región del Magdalena Medio, lo que ocasionó miedo e inseguridad en la comunidad. Los familiares participantes reportan que las labores del campo como la pesca y la agricultura se tornaron peligrosas, debido a la injerencia de grupos paramilitares, generando desplazamiento forzado, amenazas e imposición de nuevas normas, por lo cual se advierte un cambio significativo en las actividades rutinarias y culturales.

A nivel familiar y social, se encontró que debido a la falta de espacios para expresar las emociones, se deterioraron las relaciones, primando el silencio entre los miembros de la familia, desconfianza hacia los demás, estigmatización, surgieron comportamientos que van en contra vía de un estilo de vida saludable, como incremento de consumo de alcohol y detrimento de un proyecto de vida productivo a largo plazo.

Una de las ventajas de este estudio fue identificar el impacto de los procesos judiciales adelantados y resulta lamentable encontrar que las victimas manifiestan haber sido 
revictimizadas, de modo que los procedimientos de búsqueda de justicia se convirtieron en acciones lesivas adicionales, casi al punto de hacerlas renunciar a sus derechos.

La revictimización se ha centrado en la lentitud del proceso y en la inadecuada orientación, que ha obligado a las familias a acudir a varias entidades y perder esfuerzos, pese a esto, continúan esperando y perseveran en los procesos de justicia, principalmente impulsados por la necesidad de la verdad de los hechos.

Frente a las repercusiones del proceso judicial se observó que al principio, el impacto de recibir la noticia de la desaparición del familiar, sumado a las amenazas contra la vida y la integridad de los familiares sobrevivientes, hizo que estos no instauraran la denuncia de manera oportuna, desconociendo sus derechos y el acceso a la justicia. También se identificó que se ha avanzado poco en el proceso de búsqueda de la verdad y la justicia, lo que ha derivado en situaciones de revictimización e incremento en las afectaciones psicológicas en los participantes, pues hasta el día de hoy no se tienen noticias del paradero de sus familiares y no logran ver de qué manera el Estado podrá recompensarles la pérdida de los seres queridos. Además reportan que algunos funcionarios que han atendido sus requerimientos les han dado información errónea y confusa, llevándolos de una institución a otra sin obtener respuestas concretas. Esta situación, claramente ha tenido efectos negativos, como la negación del derecho a la pronta reparación e indemnización, al fácil acceso a la justicia, pérdida de credibilidad en las instituciones, falta de continuidad en los programas de atención a víctimas, desprotección de las familias que han sido objeto de nuevas amenazas y agresiones por parte de los grupos criminales que operan en la región, prolongándose el sufrimiento a nivel psicológico.

Pese a que los hechos de desaparición forzada de Benjamín Duarte y Jeisson Duarte de la Ossa afectaron fuertemente el colectivo, la única medida mencionada por uno de los 
participantes en relación con la memoria histórica, es colocar el nombre de las víctimas a un lugar representativo de la región, bien sea una institución educativa, un monumento o un parque, de modo que los familiares no conciben medidas de reparación propiamente colectivas y esto puede ser consecuencia del desplazamiento forzado subsecuente.

Los participantes no pensaron en reparaciones colectivas por un lado, porque se desplazaron y por otro lado, porque fue tal el temor de amigos y vecinos, que estos optaron por segregarlos, para evitar ser asociados con las víctimas y blanco de nuevas victimizaciones.

También se concluye que el proceso de reparación no ha sido integral y se ha visto obstaculizado por varias circunstancias, como ya se ha mencionado, el no tener noticias del paradero del familiar, la proximidad con victimarios y la exclusión de algunos perpetradores del delito del proceso de justicia y paz. Además una de las familias recientemente vivió la pérdida de otro ser querido, del cual se está investigando su muerte, pues al parecer no fue víctima de un hecho accidental, sino de un asesinato relacionado con bandas criminales que aún operan en la región del magdalena medio, lo que genera mayor impacto, impotencia y resistencia a superar y perdonar el dolor afrontado, disminuyendo así las expectativas de reparación en relación con las garantías de no repetición de los hechos.

Desde esta perspectiva, es vital que los procesos en la reparación integral requieran de acciones conjuntas que permitan, de manera idónea, el restablecimiento de los derechos a la verdad, la justicia y reparación, fundada en el respeto a la integridad y a la honra de las víctimas, asimismo, este proyecto de investigación logra visibilizar esta problemática para hacer un llamado a poner en práctica, las medidas que están contempladas en la Convención Interamericana de Derechos Humanos ratificadas por Colombia, con responsables claros en los entes territoriales para llevar a cabo una mejor prestación del servicio de atención y 
acompañamiento a la ruta de reparación integral a las víctimas del conflicto armado descrito en la Ley 1448/11.

Por otro lado, la importancia de determinar el grado de vulnerabilidad en el que se encuentran estas familias, fue importante porque permitió generar espacios de confianza para que pudieran hablar de las situaciones a las que se han enfrentado por años, a su vez, comprender los impactos ocasionados a nivel familiar, individual y colectivo tras el hecho ocurrido, posibilitó la diferenciación de los problemas psicosociales, las trasgresiones a los derechos humanos de otros problemas de salud, en tanto su origen se ubica en el ámbito sociopolítico. Lo anterior validó la persistencia del daño en la actualidad y por tanto la necesidad de su reparación integral, la cual puede no ser demandada por los familiares, pero si motivada y asesorada por los profesionales, debido a que es un derecho indiscutible.

Asimismo, el desarrollo de este proyecto investigativo aportó una nueva construcción conceptual entorno al significado de la reparación desde los diálogos y percepciones de la victimización en Colombia, en donde se entienda la reparación como un proceso que reconozca el dolor de las víctimas, que los transforme en sobrevivientes, que los ayude a resignificar su experiencia y que entienda su duelo no solamente como un síntoma personal, sino como una consecuencia de una trauma psicosocial que ha afectado a todo un grupo social.

Para los participantes, el Estado no ha adoptado las disposiciones apropiadas en relación con la situación legal de los familiares desaparecidos, cuya suerte no ha sido esclarecida, ni en sus allegados se ha establecido un mecanismo rápido para resolver cuestiones económicas, de protección social, el derecho a la familia y los derechos de propiedad tal como lo estipula la Convención Internacional para la protección de todas las personas contra las desapariciones 
forzadas en su artículo 24, pues sus derechos de sucesión y demás se vieron vulnerados siendo difícil la obtención de una reparación en satisfacción.

Por último, sería muy importante continuar con esta investigación, teniendo como base la identificación de la percepción de los impactos psicosociales y judiciales en los familiares víctimas del delito de desaparición forzada para construir un protocolo de intervención que permita eliminar las múltiples barreras de acceso a la justicia existentes, para la satisfacción de lo que demandan las víctimas y evitar revictimizaciones, con miras a garantizar la atención en salud mental que requieren las comunidades afectadas en sus procesos de reparación, de manera que se asegure el involucramiento y la participación activa de todos los miembros de la familia, que garantice su sano desarrollo afectivo, familiar, social e individual. Incorporar además el enfoque psicosocial y diferencial en los procesos de acompañamiento para cada delito, sería otra recomendación para mejorar la ruta de atención que se ofrece actualmente a las víctimas. 


\section{Referencias}

Aguilera, T.A. (2006). Las secuelas emocionales del conflicto armado para una política pública de paz. México: Red Convergencia, 2006 Tomado de http://site.ebrary.com/lib/bibliotecaustasp/Doc?id=10149381\&ppg=7

Albaladejo, I. (2009). La desaparición forzada de personas en Colombia. Cartilla para víctimas. Disponible: http://www.hchr.org.co/publicaciones/libros/desaparición_forzada_2009.pdf

Álvarez, J. (2005). Cómo hacer investigación cualitativa. Fundamentos y metodología. México: Paidós.

Alzate, J; Sierra, E; Mendez, J y Trujillo, C. (2006). Las victimas en el nuevo sistema acusatorio en Colombia. Trabajo de posgrado para optar al título de Especialistas en Derecho Probatorio Penal. Universidad de Medellín, Universidad La Gran Colombia. Facultad de Posgrados, Área de Derecho. Armenia (Colombia)

American Psychiatric Association. (1995). Manual diagnóstico y estadístico de los trastornos mentales DSM-IV. Versión española de la cuarta edición de la obra original en lengua inglesa Diagnostic and Statistical manual of Mental Disorders: DSM-IV. Barcelona (España) Editorial Masson S.A.

American Psychological Association. (2002). Ethical principles of psychologists and code of conduct. Disponible en: http://www.apa.org/ethics/code/principles.pdf.

Amnistía Internacional (2005). Informe Colombia: garantía de impunidad. Disponible en http://alainet.org/active/8318\&lang=es

Antillón, X. (2008). Investigación- La desaparición forzada de Rosendo Radilla en Atoyac de Álvarez-Informe de afectación psicosocial. Comisión mexicana de defensa y promoción 
Percepción de reparación en familias de víctimas de desaparición forzada | 144

de los derechos humanos, a.c. Mexico. Recuperado en: http://www.cmdpdh.org/docs/radilla_pasicosocial.pdf

Arévalo, Serrato y Rodríguez (2011). La guía de atención en salud mental comunitaria específica y diferencial por crímenes de lesa humanidad para las víctimas del conflicto armado, Ministerio de la protección social, Bogotá. Colombia.

Arce, R y Fariña, F. (2007). Como evaluar el Daño Moral como consecuencia de accidentes de tráfico: validación de un protocolo de medida. Papeles del Psicólogo, 3 (28) Consejo general de colegios oficiales de psicólogos, Madrid España. Disponible en http://www.papelesdelpsicologo.es/vernumero.asp?id=1504

Arias, F y Muñoz, J. (2008). Desaparición forzada y exhumaciones. Lineamientos para el autocuidado y acompañamiento psicosocial de víctimas, funcionarias y funcionarios públicos. $1^{\text {a }}$ edición. Fundación Dos Mundos, Bogotá, Colombia

Asamblea General de las Naciones Unidas. (2006). Resolución A/RES//61/177. Convención Internacional para la protección de todas las personas contra las desapariciones forzadas. Tercera Comisión. Disponible en la página de la Biblioteca Dag Hammarskjöld de las Naciones Unidas:

http://www.un.org/ga/search/view_doc.asp?symbol=A/RES/61/177\&Lang=S

Asamblea General de las Naciones Unidas (1985). Resolución A/RES/40/34 de 29 de noviembre de 1985, Declaración sobre los Principios Fundamentales de Justicia para las Víctimas de Delito y del Abuso de Poder. Disponible en: $\underline{\text { http://daccess-dds- }}$ ny.un.org/doc/RESOLUTION/GEN/NR0/485/21/IMG/NR048521.pdf?OpenElement.

Beristain, A. (2006). Hoy creamos una nueva ciencia cosmopolita e integradora: la victimología de máximos, después de Auschwitz. 
Beristaín, C. (1999) Reconstruir el Tejido Social, un enfoque Critico de la Ayuda Humanitaria. Barcelona, Icaria Editorial

Beristain, C (2006). Verdad, justicia y reparación. Desafíos para la democracia y la convivencia social. Instituto Interamericano de Derechos Humanos.

Beristain, C y Gomez, A. (2007). Retos para el acompañamiento psicosocial de familiares de personas desaparecidas en el contexto de exhumaciones en Colombia. En resistencia contra el olvido. Trabajo psicosocial en contextos de exhumaciones en América Latina. Pau Pérez-Sales y Susana Navarro García. Barcelona: Editorial Gedisa,

Beristain, C, (2008). Diálogos sobre la reparación, experiencias en el sistema interamericano de Derechos Humanos. Tomo 2. Costa Rica: Editorial Instituto Interamericano de Derechos Humanos. En revista Universitas. Bogotá D.C. tomado de http://javeriana.edu.co/juridicas/pub_rev/documents/beristain13.pdf.

Beristain, C. (2008). Diálogos sobre la reparación, experiencias en el sistema interamericano de Derechos Humanos. Tomo 1. Costa Rica: Editorial Instituto Interamericano de Derechos Humanos.

Beristain, C. (2010). Manual sobre perspectiva psicosocial en la investigación de derechos humanos. España. Edita: Instituto Hegoa - Universidad del País Vasco y Centro por la Justicia y el Derecho Internacional CEJIL. Disponible en: http://biblioteca.hegoa.ehu.es/system/ebooks/18097/original/Manual_perspectiva_psicoso cial_derechos_humanos.pdf?1283940592

Britto. D (2010). Justicia Restaurativa: Reflexiones sobre la experiencia de Colombia. Ecuador. Universidad Técnica Particular de Loja. Colección Cultura de la Paz, 44-64. 
Bruner, J.S. y Tagiuri, R. (1954). The perception of people. En G. Lindzey (Ed.), Handbook of socialpsychology (pp. 634-654). Reading, MA: Addison-Wesley.

Cabanillas, B. (2005). La desaparición forzada como modalidad represiva Central de la guerra psicológica en un contexto de Terrorismo de estado. Miedo, silenciamiento colectivo y trauma psicosocial. El caso de la dictadura militar de A. Pinochet en Chile. 1973-1990. Trabajo de grado de Magister. Universidad de Deusto. Instituto de Derechos Humanos Pedro Arrupe. Bilbao-España. Recuperado en: http://www.psicosocial.net/es/component/docman/doc_details/298-la-desaparicionforzada-como-modalidad-represiva-en-un-contexto-de-terrorismo-de-estadochile

Camargo, E. (2012). Los derechos de las víctimas en el proceso penal colombiano. Revista Republicana, 12, 17-42.

Cabrera, L, y Martín Beristain, C. (2000). Resistiendo a la impunidad en Guatemala. La dimensión psicosocial en un proceso político-judicial. En Revista Nueva Sociedad, 175, 43-58.

Cáceres, E. (2008). Trabajo de grado. La desaparición forzada en Colombia, un mecanismo estatal para controlar y disciplinar a la oposición política y a la sociedad en general. Pontificia Universidad Javeriana. Bogotá-Colombia. Recuperado en: http://www.javeriana.edu.co/biblos/tesis/politica/tesis207.pdf

Cañas, J. y Tapias, A. (2012). En los laberintos mentales de Garavito. Dos psicólogos jurídicos reflexionan sobre le mayor asesino sexual serial de niños en Colombia. Editorial SIC. Bucaramanga, Colombia.

Centro de Investigación y Educación Popular CINEP. (2004). Barrancabermeja, la otra versión paramilitarismo, control social y desaparición forzada 2000-2003. Caso tipo $\mathrm{N}^{\circ} 3$. 
Percepción de reparación en familias de víctimas de desaparición forzada 147

Bogotá: Panorama de Derechos Humanos y violencia política en Colombia Noche y Niebla.

Centro de Investigación y Educación Popular CINEP. (2008). Marco Conceptual. Banco de Datos de Derechos Humanos y Violencia Política. Segunda Edición, Bogotá D.C.

Colegio Colombiano de Psicólogos (2012). AcuerdoNo.10 manual deontologico y bioetico del psicologo.

Recuperado

en http://www.colpsic.org.co/portal/tribunales_archivos/ACUERDO_No_10_MANUAL_D EONTOLOGICO_Y_BIOETICO_DEL_PSICOLOGO_Marzo_15_2012.pdf

Comisión Colombiana de Juristas. (2004). Colombia: En Contravía de las Recomendaciones Internacionales sobre Derechos Humanos. Bogotá: Organización no gubernamental con estatus consultivo ante la ONU, Filial de la Comisión Andina de Juristas (Lima) y de la Comisión Internacional de Juristas (Ginebra).

Comisión de Derechos Humanos (2005), resolución 2005/35. Principios y directrices básicos sobre el derecho de las víctimas de violaciones de las normas internacionales de derechos humanos y del derecho internacional humanitario a interponer recursos y obtener reparaciones.

Comisión Nacional de Reparación y Reconciliación. (2009). Criterios para la identificación del daño psicológico en el marco del programa de reparación individual por vía administrativa para las víctimas de los grupos armados organizados al margen de la ley. Bogotá.

Congreso de la República de Colombia (1997). Ley 418 de 1997 por la cual se consagran unos instrumentos para la búsqueda de la convivencia, la eficacia de la justicia y se dictan otras disposiciones. Diario Oficial No. 43.201 de 26 de diciembre de 1997. Disponible en 
la página oficial de la Secretaria del Senado del Congreso de la República de Colombia: http://www.secretariasenado.gov.co/senado/basedoc/ley/1997/ley_0418_1997.html

Congreso de la República de Colombia (2000). Ley 599 de 2000. Por la cual se expide el Código Penal. Diario Oficial No. 44.097 de 24 de julio de 2000. Disponible en la página oficial de la Secretaría del Senado del Congreso de la República de Colombia: http://www.secretariasenado.gov.co/senado/basedoc/ley/2000/ley_0599_2000.html

Congreso de la República de Colombia (2000). Ley 600 de 2000. Por la cual se expide el Código de Procedimiento Penal. Diario Oficial No. 44.097 de 24 de julio de 2000. Disponible en la página oficial de la Secretaría del Senado del Congreso de la República de Colombia: http://www.secretariasenado.gov.co/senado/basedoc/ley/2000/ley_0600_2000.html

Congreso de la República de Colombia (2004). Ley 906 de 2004. Por la cual se expide el Código de Procedimiento Penal. Diario Oficial No. 45.657 de 31 de agosto de 2004. Disponible en la página oficial de la Secretaría del Senado del Congreso de la República de Colombia:

http://www.secretariasenado.gov.co/senado/basedoc/ley/2004/ley_09060_204a.html

Congreso de la República de Colombia (2005). Ley 971 del 2005. Por medio de la cual se reglamenta el mecanismo de búsqueda urgente y se dictan otras disposiciones. Diario Oficial No. 45.970 de 15 de julio de 2005. Disponible en la página oficial de la Secretaría del Senado del Congreso de la República de Colombia: http://www.secretariasenado.gov.co/senado/basedoc/ley/2005/ley_0971_2005.html

Congreso de la República de Colombia (2005). Ley 975 de 2005. Por la cual se dictan disposiciones para la reincorporación de miembros de grupos armados organizados al margen de la ley, que contribuyan de manera efectiva a la consecución de la paz 
nacional y se dictan otras disposiciones para acuerdos humanitarios. Diario Oficial No. 45.980 de 25 de julio de 2005. Disponible en la página oficial de la Secretaría del Senado del Congreso de la República de Colombia: http://www.secretariasenado.gov.co/senado/basedoc/ley/2005/ley_0975_2005.html

Congreso de la República de Colombia (2006). Ley 1090 (2006). Por la cual se reglamenta el ejercicio de la profesión de Psicología, se dicta el Código Deontológico y Bioético y otras disposiciones. Diario Oficial No. 46.383 de 6 de septiembre de 2006. Disponible en la página oficial de la Secretaria del Senado del Congreso de la República de Colombia: http://200.75.47.49/senado/basedoc/ley/2006/ley_1090_2006.html

Congreso de la República de Colombia (2011). Ley 1448 de 2011 Por la cual se dictan medidas de atención, asistencia y reparación integral a las víctimas del conflicto armado interno y se dictan otras disposiciones. Diario Oficial No. 48.096 del 10 de junio de 2011. Disponible en la página oficial de la Secretaria del Senado del Congreso de la República de Colombia: http://www.secretariasenado.gov.co/senado/basedoc/ley/2011/ley_1448_2011.html

Constitución Política de la República de Colombia, (1991). Segunda edición corregida de la Constitución Política de Colombia, publicada en la Gaceta Constitucional No. 116 de 20 de julio de $1991 . \quad$ Disponible en: http://www.secretariasenado.gov.co/senado/basedoc/cp/constitucion_politica_1991.html Convención Interamericana sobre Desaparición Forzada de Personas, (1994). Asamblea General de la Organización de los Estados Americanos. Brasil. Consultado en http://www.acnur.org/t3/fileadmin/scripts/doc.php?file=biblioteca/pdf/0030 
Corporación Jurídica Libertad. (2009). Desaparición Forzada, crimen de Lesa Humanidad. Consultado en:

http://www.cjlibertad.org/index.php?option=com_content\&view=article\&id=248:desapar $\underline{\text { icion-forzada-crimen-de-lesa.humanidad- } \& \text { catid=50:hazlojusto } \& \text { Itemid }=90}$

Corporación de Desarrollo y Paz del Magdalena Medio CORDEPAZ. (2013). Protocolo de atención psicosocial estudio de caso sobre la ruta de atención psicosocial a víctimas de la violencia (desaparición forzada). Convenio CCO-15/2013 Ecopetrol, Redpordepaz y Cordepaz. Barrancabermeja, Colombia.

Corte Constitucional de Colombia (2011). Sentencia C-620/11 por medio de la cual se aprueba la Convención internacional para la protección de todas las personas contra las desapariciones forzadas', adoptada en Nueva York el 20 de diciembre de 2006". Disponible en la página oficial del Corte Constitucional de Colombia: http://www.corteconstitucional.gov.co/relatoria/2011/c-620-11.htm

Corte Constitucional de Colombia (2005). Sentencia C-370/06 por la cual se hace control de constitucionalidad de ley de justicia y paz-ponderación de la paz, la justicia y los derechos de las víctimas. Disponible en la página oficial del Corte Constitucional de Colombia: http://www.corteconstitucional.gov.co/relatoria/2006/c-370-06.htm

Consejo Económico y Social de las naciones Unidas, Comisión de Derechos Humanos (2005). $61^{\circ}$ periodo de Sesiones, Conjunto de principios actualizado para la protección y la promoción de los derechos humanos mediante la lucha contra la impunidad E/CN./2005/102/Add. 1, 8.

Declaración sobre la protección de todas las personas contra las desapariciones forzadas (1992).Aprobada por la Asamblea General en su 
Percepción de reparación en familias de víctimas de desaparición forzada $\mid 151$

resolución 47/133 de 18 de diciembre 1992 consultado enhttp://www.unhchr.ch/huridocda/huridoca.nsf/(Symbol)/A.RES.47.133.Sp?OpenDocu

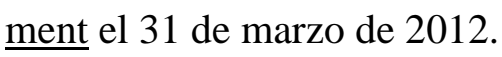

Díaz, F (2008). La Justicia transicional y la Justicia restaurativa frente a las necesidades de las víctimas. Bogotá, Umbral Científico, No. 012, 119-123, recuperado de http://redalyc.uaemex.mx/src/inicio/ArtPdfRed.jsp?iCve=30401210, fecha de consulta septiembre de 2011.

Díaz, F (2009). El Daño Psicológico y la Violencia Política desde una Perspectiva Psicojurídica. Bogotá, Umbral Científico, No. 012, 119-123. Recuperado de http://redalyc.uaemex.mx/src/inicio/ArtPdfRed.jsp?iCve=30401210, fecha de consulta septiembre de 2011.

Díaz, V. (2008). Del dolor al duelo: límites al anhelo frente a la desaparición forzada. Revista electrónica: AffectioSocietatis, 9, recuperada el 01 de septiembre de 2011, de http://revinut.udea.edu.co/index.php/affectiosocietatis/article/viewFile/5323/6578

Duque, L. (2011). Fundamentos de psicología jurídica: conferencia 05. En: seminario de psicología jurídico forense (1º: 2011: Santa Fe de Bogotá). Memorias del Seminario de Psicología Jurídica Forense. Santa fe de Bogotá. Iberoamericana, 2011. p. 22 -24.

Echeburúa, E; Paz de Corral \& Amor, P (2002). Evaluación del daño psicológico en las víctimas de delitos violentos. Revista Psicothema. 14. Universidad del país Vasco. España. Recuperado el 3 de octubre de 2011, de http://www.ehu.es/echeburua/pdfs/17danopsi.pdf 
Percepción de reparación en familias de víctimas de desaparición forzada $\mid 152$

Echeburúa, E. y Corral, P. (2005). ¿Cómo Evaluar las Lesiones Psíquicas y las Secuelas Emocionales en las Víctimas de Delitos Violentos? Revista Psicopatología Clínica, Legal y Forense, 5, 58-59.

Fernández, L. (2006). ¿Cómo analizar datos cualitativos?, ficha 7. Butlletí La Recerca ISSN: 1886-1946 / Depósito legal: B.20973-2006. Universidad de Barcelona Instituto de Ciencias de la Educación sección de Recerca. Recuperado el 02 de septiembre de 2014: http://www.ub.edu/ice/recerca/pdf/ficha7-cast.pdf

Ferreiro, B. (2005). La Víctima en el Proceso Penal. España: La ley.

Fundación Dos Mundos (2008), Desaparición Forzada, una mirada psicosocial a la danza entre la noche y la niebla. Revista Razones y Emociones. 18. Recuperado el 28 de agosto de 2011, de http://www.dos-mundos.org/pdf/revista/sinras_018.pdf

Fundación Dos Mundos, (2005). A la hora de la verdad: lo psicosocial en la justicia transicional. En Revista Razones y Emociones. 14. Recuperado el 27 de agosto de 2011, de http://www.dos-mundos.org/pdf/revista/sinras_014.pdf

Fundación Dos Mundos, (2005). Reparación Psicosocial: más que compensación. En Revista Razones y Emociones. 16. Recuperado 15 de Agosto de 2011, http://www.dosmundos.org/pdf/revista/sinras_016.pdf

Fundación Dos Mundos, (2006).Cómo aporta lo psicosocial a una reparación integral. En Revista Razones y Emociones. 17. Recuperado el 23 de agosto de 2011, de http://www.dos-mundos.org/pdf/revista/sinras_017.pdf

Gómez, G y Muñoz, C. (2012). Proceso de articulación y fortalecimiento de redes territoriales de víctimas. Escuela de formación. Módulo de desaparición forzada. Fondo de Justicia 
Transicional, Programas de Promoción de la Convivencia y Fortalecimiento de la Justicia.

Gómez, N (2009). Peritaje psicosocial por violaciones a derechos humanos. Guatemala. Equipo de estudios comunitarios y acción psicosocial, F\&G Editores.

Gómez, O (2006) Voces de Memoria y Dignidad Material Pedagógico Sobre Reparación Integral Módulo Aspectos Psicosociales de la Reparación Integral, Primera edición. Corporación AVRE - Apoyo a Víctimas de Violencia socio-política pro Recuperación Emocional.

Gómez, O y Álvarez, L (2009) Manual de Buenas Prácticas en Atención Psicojurídica, Bogotá D.C. Corporación AVRE - Apoyo a Víctimas de Violencia socio-política pro Recuperación Emocional.

Guilis, G (2001). Concepto de reparación simbólica. Equipo de Salud Mental del CELSEditorial Universitaria de Buenos Aires EUDEBA. Argentina.

Guski, R. (1992). La percepción. Diseño psicológico de la información humana. Barcelona, España: Editorial Herder.

Gutiérrez de Piñeres, C., Coronel, E., y Pérez, C. A. (2009). Revisión teórica del concepto de victimización secundaria. Liberabit. Revista de Psicología. Vol. (15), Núm. 1, 49-58. Disponible en: http://www.redalyc.org/pdf/686/68611923006.pdf

Gutiérrez de Piñeres, C (2010). Procesos de duelo en víctimas de desaparición forzada. Recuperado el 01 de septiembre de 2011, disponible en: http://psicologiajuridica.org/psj137.html

Gutiérrez de Piñeres, C. (2010). Revisión sobre la definición de Psicología Jurídica. Revistas Diversitas. Perspectivas en la psicología, 6, pp. 223. Bogotá

Hernández, G. (2011). Piscología Jurídica Iberoamericana, Bogotá: Editorial Manual Moderno. 
Hernández, S, Fernández, C y Baptista, M. (2010). Metodología de la Investigación. Quinta Edición. Editorial Mc Graw Hill. México D.F.

Ibáñez, T. (1994). Psicología social construccionista. Guadalajara: Universidad de Guadalajara. México.

Instituto Nacional de Medicina Legal y Ciencias Forenses, (2001). Guía práctica para el dictamen de lesiones personales INMLYCF. p.05

Instituto Nacional de Medicina Legal y Ciencias Forenses, (2011). Guía para la realización de pericias psiquiátricas o psicológicas forenses sobre daño psíquico con fines de indemnización, conciliación o reparación. Bogotá, D.C.

Instituto Nacional de Medicina Legal y Ciencias Forenses, (2014). Sistema de Información Red de Desaparecidos y Cadáveres - SIRDEC. Life, localización de información forense estadística. Recuperado

de http://sirdec.medicinalegal.gov.co:58080/mapaDesaparecidos/faces/mapa.xhtml

Jiménez, C. (2010). Tareas pendientes, Propuestas para la formulación de políticas públicas de reparación en Colombia. Bogotá. Centro Internacional para la Justicia Transicional. Banco de la República, Biblioteca Luis Ángel Arango. López, W. Pearson, A. Ballesteros, B. (2008). Aproximación Psicosocial a las Victimas (Pág. 59-70) Bogotá: Pontificia Universidad Javeriana.

López, W. Pearson, A. Ballesteros, B. (2008). Experiencia del centro de atención Psicosocial CAPS- en el acompañamiento a la población afectada por la violencia sociopolítica en Colombia (Pág.127-167) Bogotá: Pontificia Universidad Javeriana. 
Márquez Cárdenas, A. E. (2011). La victimología como estudio. Redescubrimiento de la víctima para el proceso penal. Prolegómenos. Derechos y Valores, XIV (27) 27-42. Recuperado de http://www.redalyc.org/articulo.oa?id=87619038003

Martín-Baró I. (1990). Psicología Social de la Guerra: Trauma y Terapia. Uca Editores, San Salvador, El Salvador.

Ministerio de Salud de la República de Colombia (1993). Normas científicas, técnicas y administrativas para la investigación en salud Resolución 8430 de 1993. Disponible en: http://www.minsalud.gov.co/Normatividad/RESOLUCION\%208430\%20DE\$201993.pdf

Ministerio de la protección social (2012). Programa de Atención Psicosocial y Salud Integral a Víctimas (2012), en el marco de la ley 1448 de 2011.

Movimiento Nacional de Víctimas de Crímenes de Estado MOVICE. (2009). Sin Justicia y Sin Paz. Verdad Fragmentada, Reparación Ausente. Balance de la aplicación de la "Ley de Justicia y Paz”, Bogotá D.C. Fundación Comité de Solidaridad con los Presos Políticos Corporación Colectivo de Abogados José Alvear Restrepo.

Munne, H. (1989). Entre el individuo y la sociedad. Barcelona, PPU.

Muñoz-Sabaté, L., Bayés, R. y Munné F. (1980). Introducción a la Psicología Jurídica. México: Editorial Trillas. P. 125.

Naciones Unidas de Colombia (s.f). Recomendaciones contra el delito de Desaparición Forzada en Colombia. Disponible en http://www.nacionesunidas.org.co/index.shtml?apc=uu--1-$\underline{\& x}=58900$

Naciones Unidas. (1998). Estatuto de Roma de la Corte Penal Internacional. Disponible en: http://www.hchr.org.co/documentoseinformes/documentos/html/pactos/estatuto_roma_co rte_penal_internacional.html 
Percepción de reparación en familias de víctimas de desaparición forzada 156

Observatorio de Paz Integral OPI. (2011) Informe de actores armados de tipo paramilitar en el Magdalena Medio 2011. Barrancabermeja, Colombia. Disponible en: http://www.opi.org.co/pdfs/PARAMILITARISMO\%20MM.pdf

Observatorio Internacional sobre el proceso de DDR y la Ley de Justicia y Paz. (2011). Cuarto Informe. Septiembre de 2011. Centro Internacional de Toledo para la Paz CITpax, Madrid, pp 12

Oficina del Alto Comisionado de Naciones Unidas para los Derechos Humanos y Comité Internacional de la Cruz Roja. (2009). Recomendaciones para una política pública con enfoque psicosocial en contra de la desaparición forzada. Primera edición. Bogotá. Nuevas Ediciones S.A.

Organización Mundial de la Salud. (1995). International Personality Disorder Examination (IPDE)-DSM-IV module. Edición española. Editorial Meditor. Madrid, España.

Oviedo, G. (2004). La definición del concepto de percepción en Psicología con base en la teoría Gestalt. Revista de Estudios Sociales No. 18. Facultad de Ciencias Sociales, Universidad de los Andes, Bogotá. Disponible en: http://res.uniandes.edu.co/view.php/375/view.php

Oyarbide, M (2004). Jerome Seymour Bruner: de la percepción al lenguaje. Revista Iberoamericana de Educación (ISSN: 1681-5653). 6ta. Edición. Ediciones Morata. Madrid.

Palacios, L y Heinze, G. (2002). Trastorno por estrés postraumático: Una revisión del tema (primera parte). Revista Salud Mental, Vol. 25, No. 3. México D.F.

Paris, L. (2009). Consideraciones Para la Optimización de la Política Pública Entorno a la Desaparición Forzada en Colombia y Recomendaciones para los Programas de 
Reparación Integral a los Familiares Sobrevivientes. Trabajo de grado para optar el título de Maestría en Política Social. Pontificia Universidad Javeriana. Colombia.

Pérez-Sales, P. y Navarro, S. (2007). Resistencias contra el olvido. Trabajo psicosocial en procesos de exhumaciones. España: Gedisa. Recuperado de: file:///C:/Users/user/Downloads/perezsales-navarro---resistencias-contra-el-olvido.pdf

Porta, L; Silva, M. (2003) La investigación cualitativa: El Análisis de Contenido en la investigación Educativa. Disponible

en <http://www.uccor.edu.ar/paginas/REDUC/porta.pdf>

Procuraduría General de la Nación. (2009). Valoración de los programas oficiales de atención psicosocial a las víctimas del conflicto armado interno en Colombia. Bogotá. Opciones Gráficas Editores Ltda.

Quintero. (2010). Propuesta para el acompañamiento a víctimas de desaparición forzada en Colombia desde la antropología forense. Construcción desde la experiencia con organizaciones no gubernamentales defensoras de derechos humanos. Universidad Nacional de Colombia, Facultad de Ciencia Humanas, Departamento de Antropología, Bogotá D.C.

Rebolledo, O y Rondón, L. (2010) Reflexiones y aproximaciones al trabajo psicosocial con victimas individuales y colectivas en el marco del proceso de reparación. Revista de Estudios Sociales No. 36. Facultad de Ciencias Sociales, Universidad de los Andes, Bogotá.

Rivera, C. (2009). Del delito permanente a la doctrina Hanke Velasco, el delito de la desaparición forzada en las sentencias de la Sala Penal Nacional. Lima. 
Rodríguez y Ávila. (1999). Evaluación, Psicopatología e Intervención en Psicología Forense. Madrid: Universidad. Cap. 2, P. 29-32.

Rodríguez, P. G. (2000). Atención Psicosocial a poblaciones víctimas de la violencia y el conflicto armado, Bogotá: Universidad Nacional de Colombia.

Sentencia de la Corte Constitucional de Colombia $\mathrm{N}^{\circ}$ 100/11. Disponible en: http://www.corteconstitucional.gov.co/relatoria/2011/C-100-11.htm

Spielberger, C.D. (2008). Inventario de depresión estado-rasgo IDER. Madrid, España: TEA Ediciones S.A.

Spielberger, C.D., Gorsuch, R.L. y Lushene, R.E. (2011). Cuestionario de ansiedad estado-rasgo STAI. ( $8^{\mathrm{a}}$ ed.). Madrid, España: TEA Ediciones S.A.

Sicard, R. (2011). El daño psíquico a partir del concepto de daño moral en víctimas del conflicto armado colombiano. Edición 07. Barrancabermeja: Revista Agenda Pública, p.25-28.

Suarez, K; Valdéz, L. (2013). Significados construidos por estudiantes universitarios; sobre daño psicosocial, la reparación de las víctimas y el papel de la comunidad. Trabajo de grado para obtener el título de Magister en Psicología Jurídica, Universidad Santo Tomas, Bogotá, Colombia.

Unidad Nacional de Fiscalías para la Justicia y la Paz, (2011). Gestión Unidad Nacional De Fiscalías Para La Justicia Y La Paz A 31 De julio De 2011. Recuperado el 25 de septiembre de 2011, de http://www.fiscalia.gov.co/justiciapaz/index.htm

Ulloque, M. (2009). Análisis de la reparación integral desde el marco de la ley 975 de 2005 sobre justicia y paz, estudio de caso (asociación de trabajadores campesinos del carare -atcc-), trabajo de grado para optar el título de magister en política social. Pontificia Universidad Javeriana. Bogotá, Colombia. 
Percepción de reparación en familias de víctimas de desaparición forzada | 159

Vallejo, M. (2008). Código de Procedimiento Legal. Bogotá: Editorial Leyer.

Vargas-Melgarejo, L. M. (1994). Sobre el concepto de percepción. Alteridades, 4(8) 47-53.

Recuperado de http://www.redalyc.org/articulo.oa?id=74711353004. 


\section{Apéndice A}

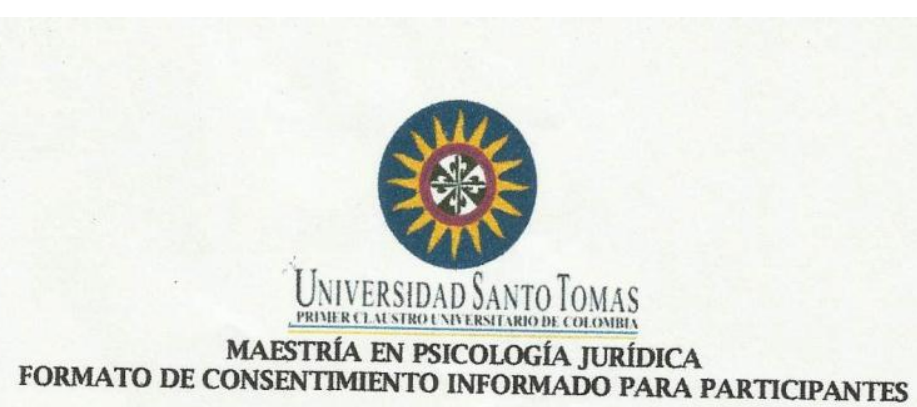

Barrancabermeja, 30 de Marzo de 2013

Yo, Sclorm preo de La Osa he sido informado (a) por las Psicólogas LILIANA MORA PACHECO identificada con la C.C No. 1.098 .622 .385 y TP 107515 del COLPSIC y ASTRID MARITZA MATEUS CUBIDES identificada con la C.C No. 1.049 .605 .209 y TP 109560 del COLPSIC, que este proceso investigativo, cuyo objetivo es explorar el daño psicosocial, el impacto de los procesos judiciales y la percepción de reparación posible en dos familias victimas de desaparición forzada en la ciudad de Barrancabermeja (Santander), no tiene fines terapéuticos, sino académicos y según sus hallazgos, los datos podrán emplearse como material probatorio judicial y que por tanto no está amparada bajo el secreto profesional. Una vez informado sobre los procedimientos que se llevarán a cabo, de la importancia de los mismos para la investigación y las consecuencias posibles que se derivarían de la imposibilidad de practicarlos, otorgo SI _.... NO _... en forma libre mi consentimiento a las Psicólogas

Como parte de la realización de este proceso investigativo autorizo efectuar:

SI $\propto$ NO _... La grabación en audio o video.

SI _ $\_$NO _._. La aplicación de pruebas psicológicas.

SI $\alpha$. NO _._. La entrevista a otros que informen sobre mi comportamiento.

SI _... NO _ _ La realización de registro fotográfico de la evaluación.

Hago constar que el presente documento ha sido leído y entendido por mí en su integridad, de manera libre y espontánea.
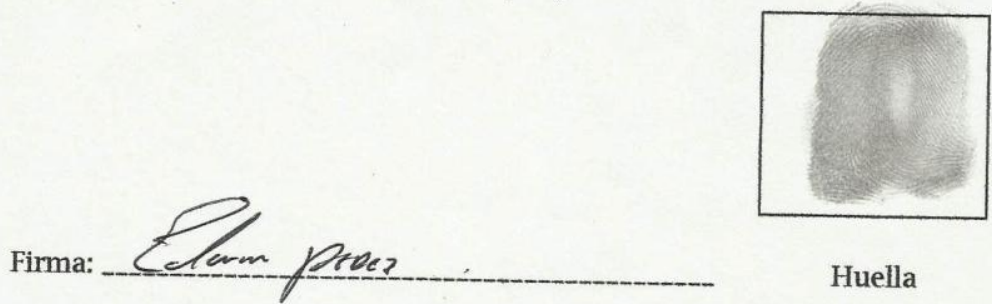

Documento de Identidad: __ 2096206950

Huella 


\section{Apéndice B}

\section{Guía de preguntas para el grupal focal con familiares:}

Las siguientes preguntas tienen el objetivo de conocer cómo vivieron la desaparición forzada de su familiar. Si hay alguna cosa que sale durante la entrevista y ustedes prefieren que no se haga pública, sientan la confianza de decirlo y esa información quedará entre nosotros.

\section{Preguntas de la categoría psicosocial}

\section{Disfunción Familiar:}

1. ¿Qué cambios en las relaciones familiares se han producido alrededor de la búsqueda (cambio de roles, desestructuración familiar, restructuración de la familia)?

2. ¿Se redistribuyeron las tareas en la familia? ¿Cómo se distribuyeron las tareas en la familia y quiénes las asumieron?

3. ¿Creen que la desaparición de su familiar tuvo impacto en los hijos y futuros nietos? ¿Cómo?

\section{Alteración de relaciones sociales}

1. ¿Cambió de alguna manera la relación de la familia con otros familiares y con la comunidad? ¿Cómo?

2. ¿Cómo eran las relaciones sociales en el período anterior a la desaparición de su familiar?

\section{Rechazo social}

1. ¿Encontraron algún apoyo en la comunidad/organización?

2. ¿Tras la desaparición del familiar, percibieron algún rechazo de su comunidad?

\section{Proximidad con los victimarios}

1. ¿En la actualidad tienen algún tipo de contacto con los perpetradores y/o sus familiares?

\section{Percepción de inseguridad}

1. ¿sintieron que su integridad o su vida estuvo en riesgo al emprender la búsqueda del familiar desaparecido?

2. ¿Qué hicieron frente a eso?

\section{Cambio cultural}

1. ¿Cambiaron sus creencias, costumbres o hábitos después de los hechos?

\section{Preguntas de la categoría revictimización}




\section{Maltrato y Negligencia institucional}

1. ¿Tuvieron acceso a recursos jurídicos para buscar a su familiar?

2. ¿Cuál ha sido la respuesta de las autoridades hasta la fecha?

3. ¿en el momento de denunciar los hechos, cómo fueron atendidos por lo funcionarios públicos?

4. ¿Qué esperan de las autoridades actualmente?

5. ¿Qué esperan del proceso legal?

\section{Reiteración del relato}

1. ¿ante las autoridades les tocó repetir la historia de lo sucedido, como se sintieron al respecto?

\section{Información errónea}

1. ¿Hubo dificultades o errores en la información que recibieron para el proceso judicial?

\section{Preguntas de la categoría percepción de reparación}

1. ¿Cómo creen ustedes que podrían repararse los daños causados por el hecho victimizante?

2. ¿De quien o quienes esperan estas medidas de reparación?

3. ¿Qué habría que hacer para que esto no se repita?

4. ¿Cómo podría convertirse la experiencia vivida en algo constructivo para la sociedad? 


\section{Apéndice C}

\section{Entrevista semiestructurada individual}

\section{Introducción:}

La entrevista que vamos a tener es acerca de la desaparición forzada de tu familiar y de cómo lo has vivido. Algunas cosas de las que vamos a conversar son recuerdos dolorosos para ti. Si en algún momento no quieres responder a una pregunta o sientes la necesidad de parar la entrevista, lo podemos hacer sin ningún problema.

Preguntas para valorar Trastornos clínicos y otros problemas que pueden ser objeto de atención clínica (depresión, ansiedad, problemas psicosomáticos, otros)

1. ¿cuánto tiempo hace que ocurrió la desaparición de (nombre del desaparecido)?

2. ¿tras la desaparición del familiar ha experimentado malestares físicos y psicológicos significativos? ¿Cuáles?

3. ¿tiene dificultades para dormir, tales como pesadillas, dificultades para conciliar el sueño?

4. ¿se siente en alerta permanente?

5. ¿Tiene dificultades para concentrarse en sus actividades cotidianas?

6 ¿desde hace cuánto experimenta esos malestares?

7 ¿antes de la desaparición le pasaban cosas similares a las que me acaba de narrar?

\section{Preguntas para valorar duelo alterado}

1. ¿ha logrado sobrellevar el dolor o recuerda las ausencia de su familiar con enorme y profunda tristeza, como su hubiera sido ayer?

2. ¿usted o algún familiar continua realizando actos de espera de (nombre del desaparecido) como por ejemplo servirle alimentos, esperarlo en la puerta o llorar todos los días por el?

3. ¿trata de evitar las cosas, personas, lugares u otras cosas que le recuerdan a (nombre del desaparecido)?

4. ¿tras la desaparición del familiar se ha sentido distante de las personas que le importan o ha tenido la sensación de haber perdido el interés por los demás?

5. A veces las personas que han perdido a un ser querido se sienten mal por seguir adelante con su vida. ¿Es difícil para usted seguir adelante con su vida, por ejemplo, hacer nuevos amigos o interesarse por cosas nuevas?

6. ¿En algún momento ha oído la voz de (nombre del desaparecido) que le habla?

7. ¿En algún momento ha visto a (nombre el fallecido) como si lo tuviera delante?

8. ¿se ha sentido culpable por la desaparición de su familiar, por qué?

\section{Preguntas para evaluar alteración en el proyecto de vida}

1. ¿después de la desaparición del familiar, han cambiado tus planes de vida tales como estudios, laborales, etc.? De qué manera?

2. ¿Qué te gustaría hacer en el futuro? 
Percepción de reparación en familias de víctimas de desaparición forzada | 164

\section{Dificultades de pareja.}

1. ¿Cambió tu manera de relacionarte en pareja a partir de la desaparición de tu familiar?

2. ¿Has tenido dificultades para establecer relaciones de pareja después de la desaparición? 


\section{Apéndice D}

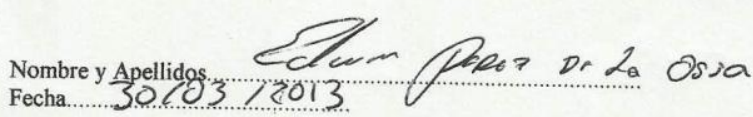

Directrices:

Cuestionario de evaluación IPDE módulo DSM-IV

1. El propósito de este cuestionario es conocer que tipo de persona ha sido usted en los últimos cinco años.

2. Por favor, no omitir ningún ítem. Si no está seguro de una respuesta, señalar la respuesta (VERDADERO o

FALSO) que le parezca más correcta. No hay límite de tiempo pero no pierda mucho tiempo pensando cuál es la respuesta correcta a un ítem determinado.

3. Cuando la respuesta sea VERDADERO, señalar con un círculo la letra V, cuando la respuesta sea FALSO, señalar con un círculo la letra $\mathrm{F}$.

Items

2. Confio en la gente que conozco

14. La mayoría de la gente es justa y honesta conmigo

16. Me siento molesto o fuera de lugar en situaciones sociales

27. Para evitar críticas prefiero trabajar solo

34. no me gusta relacionarme con gente hasta que no estoy seguro(a) de que les gusto

36. Creo que mi cónyuge (amante) me puede ser infiel

38. Cuido mucho lo que les digo a los demás sobre mí

39. Me preocupa mucho no gustar a la gente

51. Tengo miedo a ponerme en ridiculo ante gente conocida

58. Descubro amenazas ocultas en lo que me dicen algunas personas

63. Evito las actividades que no me resulten familiares para no sentirme molesto tratando de hacerlas

66. He sido víctima de ataques injustos sobre mi carácter o mi reputación

72. Mantengo rencores contra la gente durante años

76. Cuándo conozco a alguien no hablo mucho

Resumen de la puntuación del cuestionario de evaluación IPDE módulo DSM-IV.

Nombre y Apellidos. Fecha. 
Percepción de reparación en familias de víctimas de desaparición forzada | 166

\section{Apéndice E}

\section{STAI}

Apellidos y nombre De La OSSa Guzman

Edad 49 Sexo: Varón $\times$ Mujer

Fecha 3010312013

Centro

Curso/puesto

Otros datos

\begin{tabular}{|c|c|c|c|c|c|}
\hline$A-E$ & $\begin{array}{l}\text { A continuación, encontrará unas frases que se utilizan corrientemente para describirse uno a si mismo. } \\
\text { Lea cada frase y rodee la puntuación }(0 \text { a } 3) \text { que indique mejor cómo se SIENTE VD. AHORA MISMO, } \\
\text { en este momento. No hay respuestas buenas ni malas. No emplee demasiado tiempo en cada frase y } \\
\text { conteste señalando la respuesta que mejor describa su situación presente. }\end{array}$ & $\begin{array}{l}\frac{\pi}{0} \\
\frac{\pi}{2}\end{array}$ & & & \\
\hline 1 & Me siento calmado. & 0 & $1:$ & 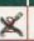 & 3 \\
\hline 2 & Me siento seguro. & 0 & 1 & $x$ & 3 \\
\hline 3 & Estoy tenso. & 0 & 1 & 2 & $x$ \\
\hline 4 & Estoy contrariado. & $0-7$ & $x$ & 2 & 3 \\
\hline 5 & Me siento cómodo (estoy a gusto). & 0 & 1 & 2 & $x$ \\
\hline 6 & Me siento alterado. & $x$ & 1 & 2 & 3 \\
\hline 7 & Estoy preocupado por posibles desgracias futuras. & 0 & $x$ & 2 & 3 \\
\hline 8 & Me siento descansado. & $0>$ & $x$ & 2 & 3 \\
\hline 9 & Me siento angustiado. & $0 \gamma$ & $x$ & 2 & 3 \\
\hline 10 & Me siento confortable. & 0 & & $x$ & 3 \\
\hline 11 & Tengo confianza en mí mismo. & 0 & 1 & & $x$ \\
\hline 12 & Me siento nervioso. & 0 & $x$ & 2 & 3 \\
\hline 13 & Estoy desasosegado. & 0 & 1 & 2 & 3 \\
\hline 14 & Me siento muy "atado" (como oprimido). & 0 ) & $x$ & 2 & 3 \\
\hline 15 & Estoty relajado. & 0 & 1 & & 3 \\
\hline 16 & Me siento satisfecho. & 0 & 1 & & 3 \\
\hline 17 & Estoy preocupado. & 0 & 1 & $x$ & 3 \\
\hline 18 & Me siento aturdido y sobreexcitado. & 0 & $x$ & 2 & 3 \\
\hline 19 & Me siento alegre. & 0 , & $x$ & 2 & 3 \\
\hline 20 & En este momento me siento bien. & 0 & 1 & $x$ & 3 \\
\hline$A-R$ & $\begin{array}{l}\text { A continuación, encontrará unas frases que se utilizan corrientemente para describirse uno a si mismo. } \\
\text { Lea cada frase y rodee la puntuación }(0 \text { a } 3 \text { ) que indique mejor cómo se SIENTE VD. EN GENERAL en la } \\
\text { mayoria de las ocasiones. No hay respuestas buenas ni malas. No emplee demasiado tiempo en cada } \\
\text { frase y conteste señalando lo que mejor describa cómo se siente Vd. generalmente. }\end{array}$ & 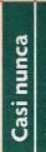 & 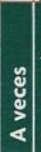 & 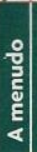 & $\frac{\mathrm{g}}{\frac{\mathrm{g}}{4}}$ \\
\hline 21 & Me siento bien. & 0 & 1 & $x$ & 3 \\
\hline 22 & Me canso rápidamente. & 0 & $x$ & 2 & 3 \\
\hline 23 & Siento ganas de llorar. & 0 & 1 & $2:$ & $x$ \\
\hline 24 & Me gustaría ser tan feliz como otros. & 0 & 1 & $2)$ & $x$ \\
\hline 25 & Pierdo oportunidades por no decidirme pronto. & 0 & 1 & $x$ & 3 \\
\hline 26 & Me siento descansado. & 0 : & $x$ & 2 & 3 \\
\hline 27 & Soy una persona tranquila, serena y sosegada. & 0 & 1 & $x$ & 3 \\
\hline 28 & Veo que las dificultades se amontonan y no puedo con ellas. & 0 & 1 & $x$ & 3 \\
\hline 29 & Me preocupo demasiado por cosas sin importancia. & 0 & 1 & $\bar{x}$ & 3 \\
\hline 30 & Soy feliz. & 0 & 1 & 2 & $x$ \\
\hline 31 & Suelo tomar las cosas demasiado seriamente. & 0 & 1 & $x$ & 3 \\
\hline 32 & Me falta confianza en mí mismo. & 0 & 1 & $\hat{2}$ & $\times$ \\
\hline 33 & Me siento seguro. & 0 & 1. 7 & $x$ & 3 \\
\hline 34 & Evito enfrentarme a las crisis o dificultades. & 0 & 1 & $\bar{x}$ & 3 \\
\hline 35 & Me siento triste (meláncolico). & $\chi$ & 1 & 2 & 3 \\
\hline 36 & Estoty satisfecho. & 0 & 1 & $x$ & 3 \\
\hline 37 & Me rondan y molestan pensamientos sin importancia. & 0 & $x$ & 2. & 3 \\
\hline 38 & Me afectan tanto los desengaños, que no puedo olvidarlos. & 0 & .1 . & $x$ & 3 \\
\hline 39 & Soy una persona estable. & 0 & 1 & 2 & $x$ \\
\hline 40 & Cuando pienso sobre asuntos y preocupaciones actuales, me pongo tenso y agitado. & 0 & 1 & 2 & $x$ \\
\hline
\end{tabular}




\section{Apéndice F}

\section{IDER Nexo $y \mathbf{M}$ Sieco

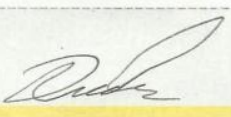 \\ Edad $3 \& \quad$ Fecha $q 4,5,1$

\section{INSTRUCCIONES}

A continuación se presentan una serie de frases que la gente usa para describirse a sí misma. Por favor, lea las correspondientes a la columna de su sexo (VARONES o MUJERES) y rodee con un círculo el número que más se aproxime a cómo se siente EN ESTE MOMENTO y GENERALMENTE. No hay respuestas correctas o incorrectas. No emplee demasiado tiempo en cada frase y trate de dar la respuesta que mejor describa sus sentimientos actuales y cómo se siente en la mayoría de las ocasiones.

DEBE CONTESTAR EN LA COLUMNA DE SU SEXO.

\section{VANRONTSS}

\begin{tabular}{|c|c|c|c|c|}
\hline $\begin{array}{c}\text { EN ESTE } \\
\text { MOMENTO... }\end{array}$ & 丞 & $\stackrel{\circ}{\frac{0}{4}}$ & 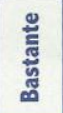 & 올 \\
\hline 1. Me siento bien & 1 & 2 & 3 & (4) \\
\hline 2. Estoy apenado & (1) & 2 & 3 & 4 \\
\hline 3. Estoy decaído & 1 & 2 & 3 & (4) \\
\hline 4. Estoy animado & 1 & 2 & (3) & 4 \\
\hline 5. Me siento desdichado & (1) & 2 & 3 & 4 \\
\hline 6. Estoy hundido & (1) & 2 & 3 & 4 \\
\hline 7. Estoy contento & 11 & 2 & 3 & (4) \\
\hline 8. Estoy triste & (1) & 2 & 3 & 4 \\
\hline 9. Estoy entusiasmado & 1 & 2 & 3 & (4) \\
\hline 10. Me siento enérgico & 1 & 2 & (3) & 4 \\
\hline
\end{tabular}

NO SE DETENGA, CONTINÚE CONTEST' NDO A LOS ELEMENTOS 11 A 20.

\begin{tabular}{|c|c|c|c|c|}
\hline GENERALEENTE... & 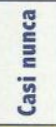 & 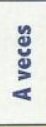 & $\begin{array}{l}\text { 율 } \\
\text { 흘 } \\
\text { 준 }\end{array}$ & 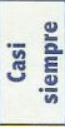 \\
\hline 11. Disfruto de la vida & 1 & 2 & 3 & 4 \\
\hline 12. Me siento desgraciado & (1) & 2 & 3 & 4 \\
\hline 13. Me siento pleno & 1 & 2 & 3 & \\
\hline 14. Me siento dichoso & 1 & 2 & 3 & (4) \\
\hline $\begin{array}{l}\text { 15. Tengo esperanzas } \\
\text { sobre el futuro }\end{array}$ & 1 & 2 & 3 & \\
\hline 16. Estoy decaido & 1 & 2 & 3 & 4 \\
\hline $\begin{array}{l}\text { 17. No tengo ganas de } \\
\text { nada }\end{array}$ & 1 & F & 3 & 4 \\
\hline 18. Estoy hundido & (1) & 2 & 3 & 4 \\
\hline 19. Estoy triste & (1) & 2 & 3 & 4 \\
\hline 20. Me siento enérgico & 1 & 2 & 3 & (4) \\
\hline
\end{tabular}

MU] ER

\begin{tabular}{|c|c|c|c|c|}
\hline $\begin{array}{c}\text { EN ESTE } \\
\text { MOMENTO... }\end{array}$ & $\begin{array}{l}\frac{\pi}{\text { d }} \\
\text { ㄹ }\end{array}$ & $\frac{\circ}{\mathrm{g}}$ & 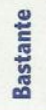 & $\frac{}{\frac{}{3}}$ \\
\hline 1. Me siento bien & 1 & 2 & 3 & 4 \\
\hline 2. Estoy apenada & 1 & 2 & 3 & 4 \\
\hline 3. Estoy decaída & 1 & 2 & 3 & 4 \\
\hline 4. Estoy animada & 1 & 2 & 3 & 4 \\
\hline 5. Me siento desdichada & 1 & 2 & 3 & 4 \\
\hline 6. Estoy hundida & 1 & 2 & 3 & 4 \\
\hline 7. Estoy contenta & 1 & 2 & 3 & 4 \\
\hline 8. Estoy triste & 1 & 2 & 3 & 4 \\
\hline 9. Estoy entusiasmada & 1 & 2 & 3 & 4 \\
\hline 10. Me siento enérgica & 1 & 2 & 3 & 4 \\
\hline
\end{tabular}

NO SE DETENGA, CONTINÚE CONTESTANDO A LOS ELEMENTOS 11 A 20.

\begin{tabular}{|c|c|c|c|c|}
\hline GENERALMENTE... & 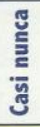 & 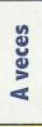 & $\begin{array}{l}\text { 율 } \\
\text { 를 } \\
\text { 른 }\end{array}$ & 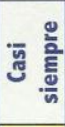 \\
\hline 11. Disfruto de la vida & 1 & 2 & 3 & 4 \\
\hline 12. Me siento desgraciada & 1 & 2 & 3 & 4 \\
\hline 13. Me siento plena & 1 & 2 & 3 & 4 \\
\hline 14. Me siento dichosa & 1 & 2 & 3 & 4 \\
\hline $\begin{array}{c}\text { 15. Tengo esperanzas } \\
\text { sobre el futuro } \\
\end{array}$ & 1 & 2 & 3 & 4 \\
\hline 16. Estoy decaída & 1 & 2 & 3 & 4 \\
\hline $\begin{array}{l}\text { 17. No tengo ganas de } \\
\text { nada }\end{array}$ & 1 & 2 & 3 & 4 \\
\hline 18. Estoy hundida & 1 & 2 & 3 & 4 \\
\hline 19. Estoy triste & 1 & 2 & 3 & 4 \\
\hline 20. Me siento enérgica & 1 & 2 & 3 & 4 \\
\hline
\end{tabular}


Percepción de reparación en familias de víctimas de desaparición forzada | 168

\section{Apéndice G}

Fuentes de información secundaria

$$
\text { PROYECTO DE VIDA Duarte }
$$

ESTADO DE PERDIDAS Y GANANCIAS - INDIVIDUAL DESPUES DEL HECHO

\begin{tabular}{|c|c|c|}
\hline ÁREA & PÉRDIDAS & GANANCIAS \\
\hline $\begin{array}{l}\text { RELACIONES } \\
\text { SOCIALES: } \\
\text { Con amigos, vecinos, } \\
\text { grupos }\end{array}$ & 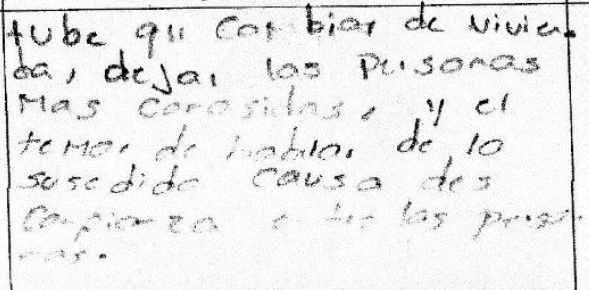 & prof $6 W^{2}$ \\
\hline $\begin{array}{l}\text { RELACIONES } \\
\text { FAMILIARES: } \\
\text { Relaciones de pareja, } \\
\text { con los hijos, padres, } \\
\text { tc. }\end{array}$ & 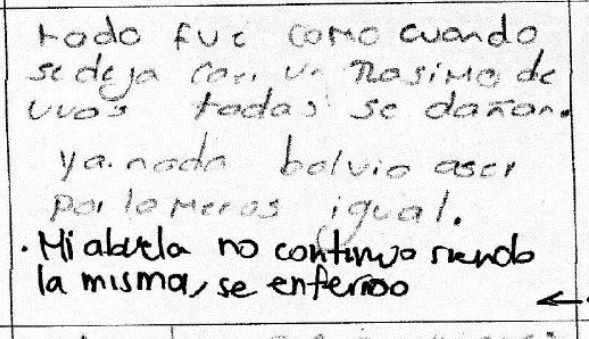 & $\begin{array}{l}\text { LAs Experie cios } \\
\text { vividas. } \\
\text { Fortalecer la relación familiar } \\
\text { con una tia quencle } \\
\text { ayudo a sus estudios. } \\
\text { - Perdieron larelación con en fioy }\end{array}$ \\
\hline $\begin{array}{l}\text { SALUD: } \\
\text { Física y mental }\end{array}$ & 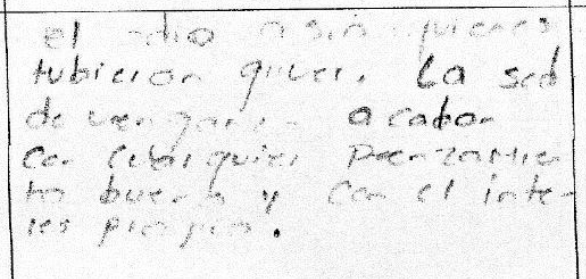 & despues de los hechos. \\
\hline $\begin{array}{lr}\text { EDUCACIÒN: } & \\
\text { Conocimientos, } & \text { nivel } \\
\text { académico } & \text { e } \\
\text { intelectual, } & \\
\text { capacitaciones } & \text { tanto } \\
\text { propias como las de la } \\
\text { familia }\end{array}$ & 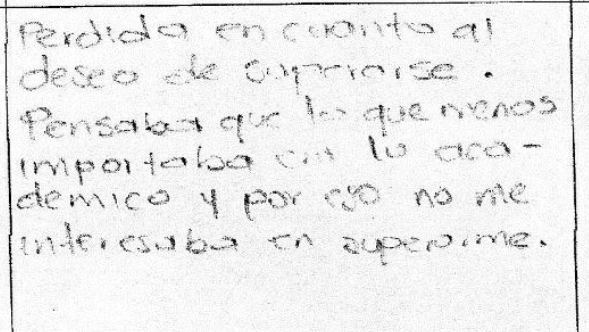 & $\begin{array}{l}\text { Estudiar y sequir capacitan } \\
\text { por sus propids nedios, sin la } \\
\text { ayuda de nadie } \\
\text { luegs mescapacite, consiquendo } \\
\text { poco a poco las metas a corfo ph } \\
\text { coperación de planta? }\end{array}$ \\
\hline $\begin{array}{l}\text { EXPERIENCIAS } \\
\text { LABORALES: } \\
\text { Desarrollo } \\
\text { oportunidades, de } \\
\text { habilidades y contactos }\end{array}$ & 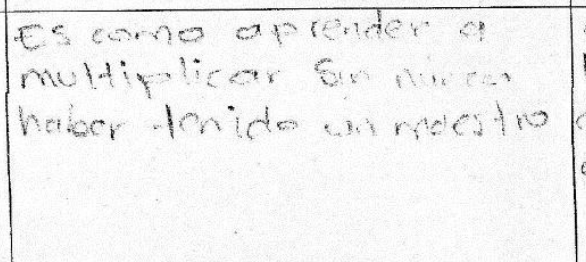 & $\begin{array}{l}\text { con el tiempo la rianza } \\
\text { los consers y el deseo } \\
\text { de no rendime me aydar } \\
\text { a encontror oportundedes }\end{array}$ \\
\hline $\begin{array}{l}\text { ECONOMIA: } \\
\text { Ahorro, deudas, } \\
\text { independencia, }\end{array}$ & 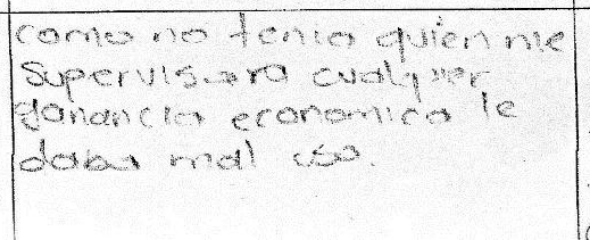 & 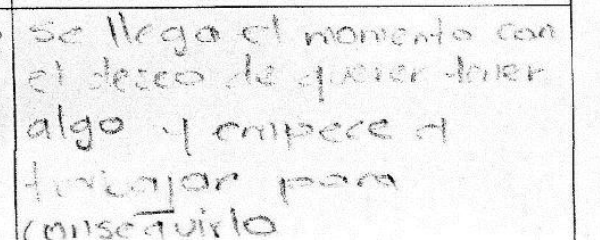 \\
\hline
\end{tabular}


Percepción de reparación en familias de víctimas de desaparición forzada $\mid 169$

\section{Apéndice H}

\section{ESTADO DE PERDIDAS Y GANANCIAS - INDIVIDUAL ANTES DEL HECHO}

\begin{tabular}{|c|c|c|}
\hline ÁREA & PĖRDIDAS & GANANCIAS \\
\hline $\begin{array}{l}\text { RELACIONES } \\
\text { SOCIALES: } \\
\text { Con amigos, vecinos, } \\
\text { grupos }\end{array}$ & $\begin{array}{l}\text { No considero } 9 \text { s haya } \\
\text { tenido peididas pues } \\
\text { vivia namal nunca } \\
\text { considere nada peidido } \\
\text { "todo era burno" }\end{array}$ & 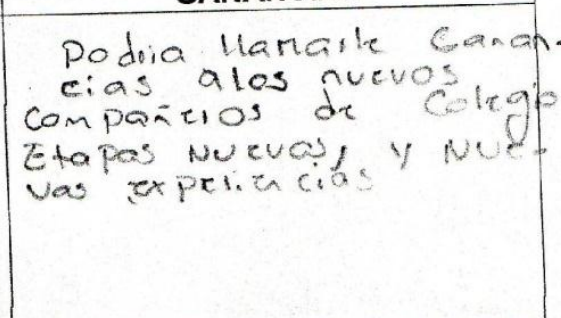 \\
\hline $\begin{array}{l}\text { RELACIONES } \\
\text { FAMILIARES: } \\
\text { Relaciones de pareja, } \\
\text { con los hijos, padres, } \\
\text { stc. }\end{array}$ & $\begin{array}{l}\text { Ya tenía } 1 \text { año de ejtar } \\
\text { separado con la pareja xk } \\
\text { peleabar mucho, sin embarg } \\
\text { rotovieron buenas relacires } \\
\text { con th actual prareja de la } \\
\text { mama. }\end{array}$ & 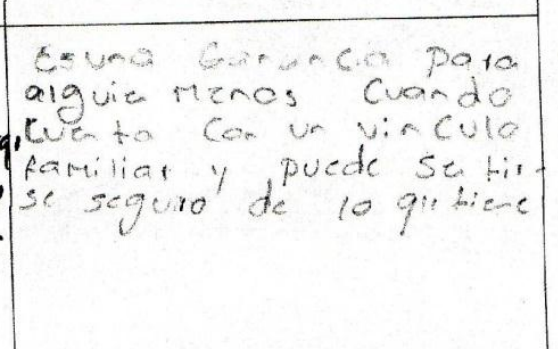 \\
\hline $\begin{array}{l}\text { SALUD: } \\
\text { Física y mental }\end{array}$ & 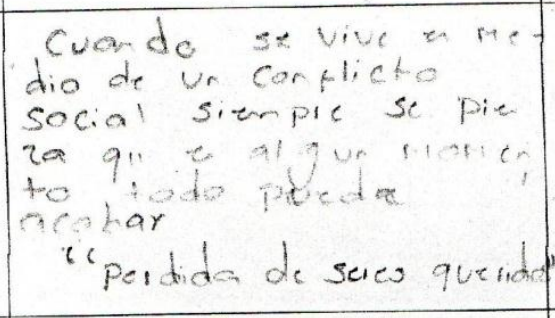 & 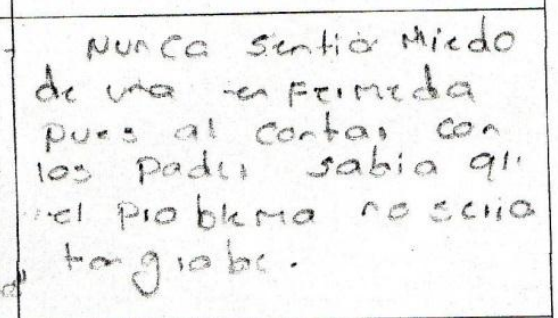 \\
\hline $\begin{array}{lr}\text { EDUCACIÒN: } & \\
\text { Conocimientos, nivel } \\
\text { académico r } \\
\text { intelectual, } \\
\text { capacitaciones } \\
\text { propias como las de la } \\
\text { familia }\end{array}$ & $\begin{array}{l}\text { Perdidas depronto al } \\
\text { vivir en un camporurol } \\
\text { se perdian al gunas } \\
\text { oportunide tes. }\end{array}$ & $\begin{array}{l}\text { Haun en condisioncs } \\
\text { Dificiles mispodies } \\
\text { logion daro atodos } \\
\text { la farmacion academice } \\
\text { posibie. }\end{array}$ \\
\hline $\begin{array}{l}\text { EXPERIENCIAS } \\
\text { LABORALES: } \\
\text { Desarrollo } \\
\text { oportunidades, } \\
\text { habilidades y contactos }\end{array}$ & $\begin{array}{l}\text { la paréa de mi mamá } \\
\text { queria que nosoftos frubaja- } \\
\text { ramsi y no erk equitativo } \\
\text { con sus of ros hijos. }\end{array}$ & 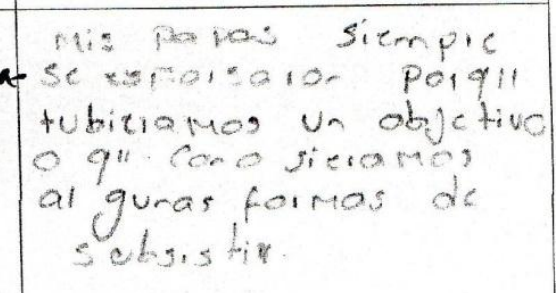 \\
\hline $\begin{array}{l}\text { ECONOMIA: } \\
\text { Ahorro, deudas, } \\
\text { independencia, } \\
\text { administración del } \\
\text { dinero. }\end{array}$ & & 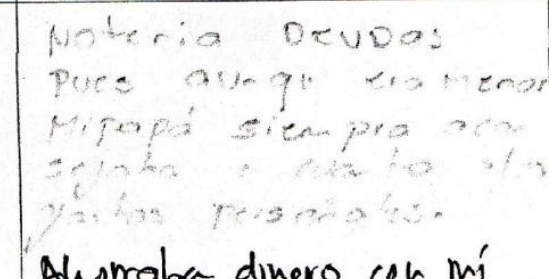 \\
\hline
\end{tabular}

